UNIVERSIDADE DE SÃO PAULO

ESCOLA DE COMUNICAÇÕES E ARTES

\title{
FLAVIANA BENJAMIN
}

\section{Poéticas de Si}

Autobiografia como estratégia artística de subversão das mulheres

São Paulo

2018 


\section{FLAVIANA BENJAMIN}

\section{Poéticas de Si}

Autobiografia como estratégia artística de subversão das mulheres

Versão Corrigida

Dissertação apresentada ao Departamento Artes Cênicas da Escola de Comunicação e Artes da Universidade de São Paulo para obtenção do título de Mestra em Artes Cênicas.

Área de concentração: Teoria e Prática do Teatro

Orientador: Prof. Dr. Ferdinando C. Martins

São Paulo

2018 
Autorizo a reprodução e divulgação total ou parcial deste trabalho, por qualquer meio convencional ou eletrônico, para fins de estudo e pesquisa, desde que citada a fonte.

Catalogação na Publicação

Serviço de Biblioteca e Documentação

Escola de Comunicações e Artes da Universidade de São Paulo

Dados inseridos pelo(a) autor(a)

Elaborado por Sarah Lorenzon Ferreira - CRB-8/6888

Benjamin, Flaviana

POÉTICAS DE SI: Autobiografia como estratégia artística de subversão das mulheres / Flaviana Benjamin ; orientador, Ferdinando C. Martins. -- São Paulo, 2018.

$110 \mathrm{p}$.

Dissertação (Mestrado) - Programa de Pós-Graduação em Artes

Cênicas - Escola de Comunicações e Artes / Universidade de São Paulo.

Bibliografia

Versão corrigida

1. Autobiografia 2. Mulheres 3. Performance Arte 4.

Movimento de Protesto 5. Estratégia I. Martins, Ferdinando

C. II. Título.

CDD 21.ed. - 700 
Benjamin, Flaviana. Poéticas de Si: Autobiografia como estratégia artística de subversão das mulheres. Dissertação apresentada à Escola de Comunicação e Artes da Universidade de São Paulo para obtenção do título de Mestra em Artes Cênicas.

Aprovada em:

Presidente da Banca: Professor Dr. Ferdinando C. Martins.

Banca Examinadora

Prof.(a). Dr(a): Instituição:

Parecer:

Assinatura:

Prof.(a). Dr(a): Instituição:

Parecer:

Assinatura:

Prof.(a). Dr(a): Instituição:

Parecer:

Assinatura: 


\section{AGRADECIMENTOS}

Agradeço ao meu querido orientador, Professor Dr. Ferdinando Martins, pela paciência, carinho e atenção com que acolheu minha pesquisa.

À minha família, em especial à minha mãe Glória e irmã Bianca, que, além de me apoiarem e ajudarem em momentos difíceis, me acolheram com carinho e paciência. Destaco minha irmã Bianca, que sempre me ajudou financeiramente em momentos de ausência de trabalho e se tornou um pilar importante neste percurso.

Às disciplinas ministradas pelos professores: Júlio de Assis (FFLCH), Silvia Fernandes (ECA), Marcelo Soler (ECA), Marcelo Denny de Toledo (ECA), Marcos Aurélio Bulhões (ECA). Aos professores de outras instituições que também contribuíram: Ana Bernstein, Tânia Alice, Maria Odette Monteiro, Vivi Tellas. E à Nina Caetano, pela participação no exame de qualificação.

À Escola de Formação Feminista e Popular do Núcleo Helenira Rezende e ao Grupo de Estudos de Arte e Gênero - GEAGE (FFLCH/USP).

Agradeço aos amigos que se lançaram neste caminho: Adão Monteiro, Carolina Ferraresi, Claudia Paim, Dada Felix, Danilo Silveira, Janaina Barros, Janaina Leite, Marcia Wayna Kambeba, Renan Dias, Vanessa Macedo e Victor de Seixas. Aos amigos da Revista Aspas, pelo aprendizado editorial.

Ao meu querido amigo de vida e arte, Tarcísio Moreira, pelo apoio; à querida Cecília Juan, pelas dúvidas nas traduções (espanhol); e todes que, de certa forma, contribuíram para a elaboração deste material.

Obrigada! 


\section{RESUMO}

O presente trabalho parte das premissas da relação entre mulheres e a produção de suas autobiografias. $\mathrm{Na}$ análise, o diagnóstico se dá pelos diversos seguimentos do dizer que borram as fronteiras do real e do ficcional, numa tentativa de dar luz a processos emancipatórios e artísticos. Inicialmente os estudos encontrados nas correntes literárias descortinam a ausência das mulheres nos espaços e segmentação histórica. Ancorada pela crítica social, a autobiografia se expande da tinta e do papel para as autorrepresentações, em que o corpo é suporte do fazer-se ver. Neste aspecto, o social e o político são usados por elas como manuseio de ações, recorrendo a performance arte, que radicalizaram temas de rechaço social, a partir da estética feminista. O campo de atuação deste diagnóstico toma, como aporte, Argentina e Brasil, nos movimentos de protesto que ajudam a pensar os espaços tensionados por elas, através de suas autobiografias, reverberando assim, um salto da singularidade para a multiplicidade de experiências pessoais potencializadas no coletivo. É, por meio do coletivo, que as experiências artísticas da pesquisadora - autobiográfica e solo - ganham relações em um corpo conjunto. Pelo material colhido nas ruas, delineia as estratégias do dizer subversivo. Um panorama que revela avanços, escolhas e modos de viver e existir.

Palavras-chave: Autobiografia. Mulheres. Performance Arte. Estratégia. Movimento de Protesto. 


\section{RESUMEN}

El presente trabajo parte de las premisas encontradas por las mujeres concernientes a sus autobiografías. En el análisis, el diagnóstico se da a través de los diversos seguimientos del discurso que borran las fronteras de lo real y ficcional en un intento de dar luz a procesos emancipatorios. Se parte inicialmente de los estudios encontrados en las corrientes literarias que revelan la ausencia de mujeres en los ámbitos y segmentación histórica. Arraigada por la crítica social, la autobiografía se expande desde la tinta y el papel hacia las auto-representaciones en las que el cuerpo es un soporte para hacerse ver. En este aspecto, tanto lo social como lo político es usado por ellas, como un manoseo de acciones a través del arte de la performance que radicalizan temas de rechazo social, por medio de la estética feminista. El campo de acción de este diagnóstico, toma como aporte Argentina y Brasil, en los movimientos de protesta que ayudan a pensar en los espacios puestos en tensión por ellas a través de sus autobiografías en un salto que va desde la singularidad hacia la multiplicidad de experiencias artísticas de la investigadora - autobiográfica y solista - ganan relaciones en un cuerpo colectivo y se apoya en pautas de reivindicación. Tomando como material de las calles la despenalización del aborto como estrategia del discurso subversivo en la instancia de investigación de campo. Un panorama que revela avances, elecciones y modos de vivir y de existir.

Palabras clave: Autobiografía. Mujeres, Arte de Performance, Estrategia, Movimientos de Protesta. 


\section{RÉSUMÉ}

Le présent travail part des prémisses que les femmes rencontrent dans la construction de leurs autobiographies. Dans l'analyse, le diagnostic se donne à travers les divers segments du dire qui brouillent les frontières du réel et de la fiction dans une tentative de donner naissance à des processus émancipateurs. Nous partons initialement d'études trouvées dans les courants littéraires qui décortiquent l'absence des femmes dans les espaces et segmentation historique. Ancrées par la critique social, l'autobiographie s'étend de l'encre et du papier aux autoreprésentations où le corps est le support du se faire voir. Dans cette perspective, le social et le politique sont utilisés par elles comme instrument d'actions à travers la performance artistique qui radicalise des thèmes de rejet social par le biais de l'esthétique féministe. Le champ d'activité de ce diagnostic s'alimente des mouvements de contestation en Argentine et au Brésil qui aident à penser les espaces tensionnées par elles à travers leurs autobiographies passant d'une singularité à une multiplicité d'expériences personnelles potentialisées dans le collectif. C'est à travers le collectif que les expériences artistiques du chercheur - autobiographie et solo - acquièrent des relations dans un corps collectif et s'appuient sur des mesures de revendications. Les stratégies du dire subversif dessinent, à partir du matériel cueilli dans les rues, un panorama qui révèle des avancées dans les choix et modes de vivre et d'exister.

Mots-clés: Autobiographie. Femmes. Performance Art. Stratégie. Mouvements de Contestation 


\begin{abstract}
The current work starts with the premises found by women as it concerns their autobiographies. In the analysis, the study occurs through diverse segments of their speech that blur the boundaries between the real and the fictional, in an attempt to shed light on emancipatory processes. Initially, it stems from studies found in literary circles that uncover the absence of women in historical spaces and segmentation. Anchored in social criticism, autobiographies expand beyond ink and paper to become selfrepresentations in which the body is a pedestal for being seen. In this aspect, the social as political is used by them, as a manipulation of actions through performance art that radicalizes themes of social rejection, by way of a feminist aesthetic. The field of activity for this study is grounded in Argentina and Brazil, in the protest movements that help imagine the spaces stressed by the women through their autobiographies in a striking leap towards multiplicity of personal experiences made possible in the collective. It is by way of the collective that the artistic experiences of the researcher solo and autobiographical - are connected in a collective body and support each other in regulatory demands. A panorama that reveals advances, choices, and modes of living and existing.
\end{abstract}

Keywords: Autobiography. Women. Performance Art. Strategy. Protest Movements. 


\section{SUMÁRIO}

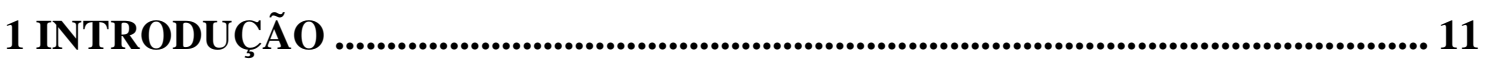

2 PISTAS E APROXIMAÇÕES DA AUTOBIOGRAFIA........................................ 14

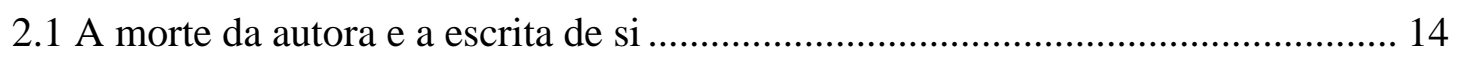

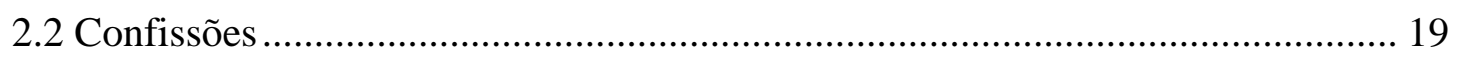

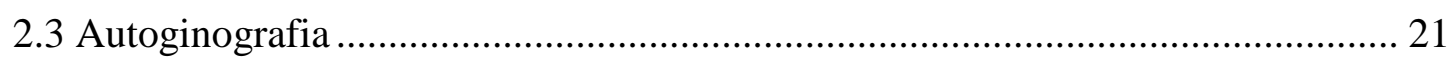

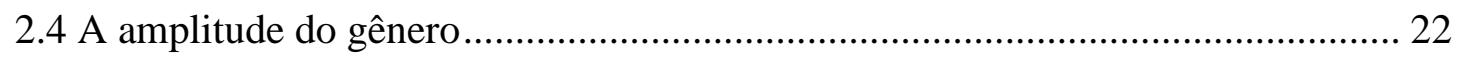

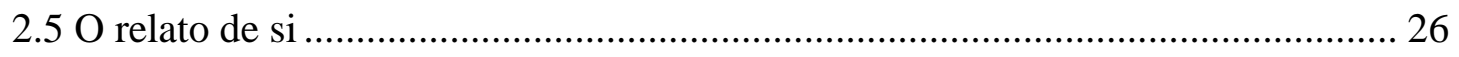

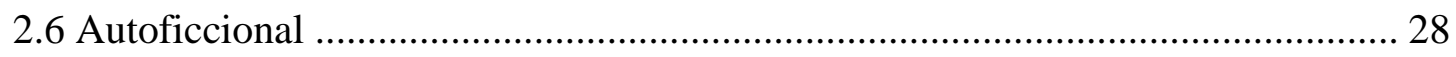

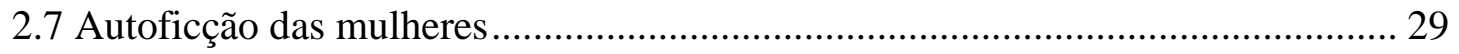

2.8 Performatividade de gênero e performance arte: territórios fixados?..................... 31

2.9 Transições autobiográficas: da escrita às práticas artísticas .................................. 34

$2.10 \mathrm{O}$ que a obra tem a dizer? .......................................................................... 35

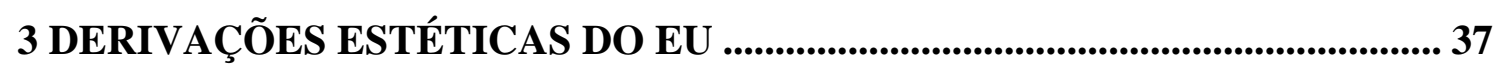

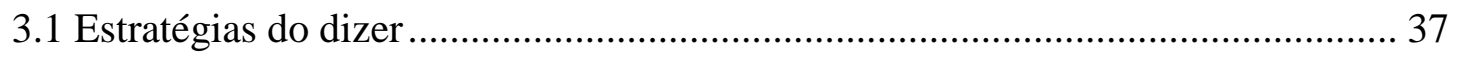

3.2 A utilização do corpo: Pose, narcisismo ou posicionamento político? .................. 39

3.3 Deslocamentos: da terra ao corpo ....................................................................... 43

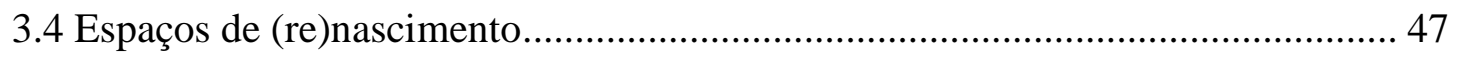

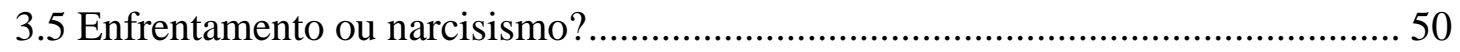

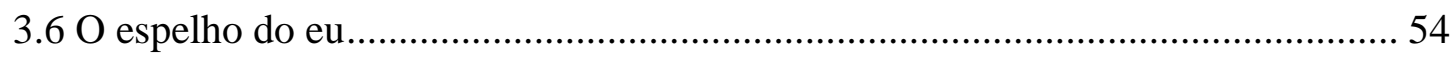

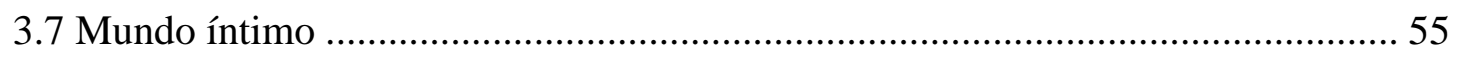

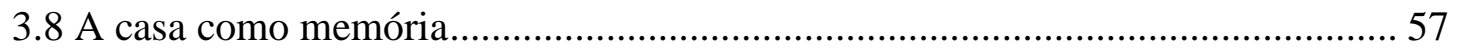

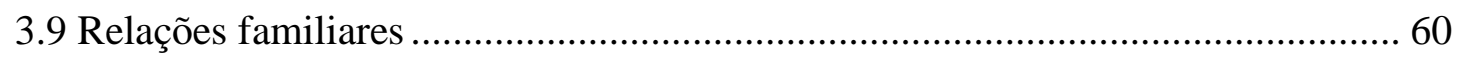

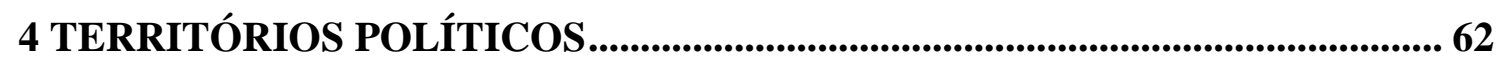

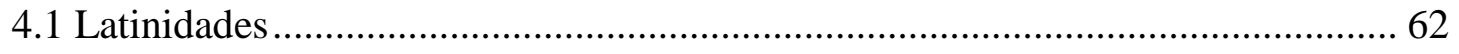

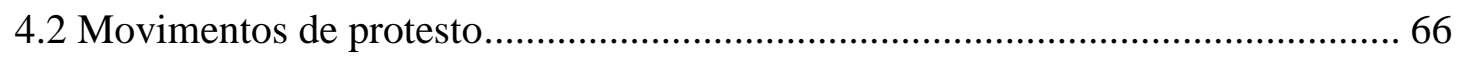

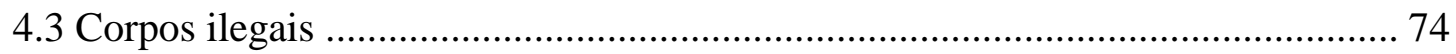

4.4 Intimidade nas ruas: Dicotomias e tensões ........................................................... 76

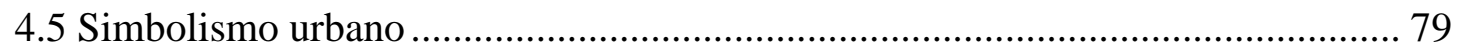

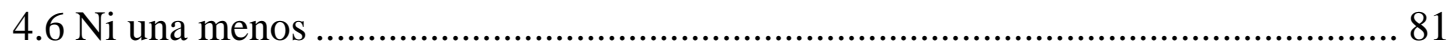

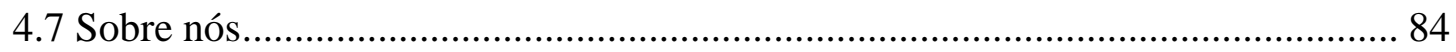

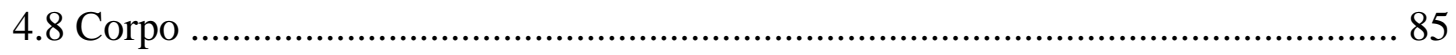

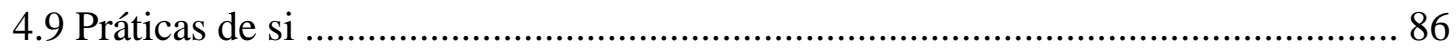




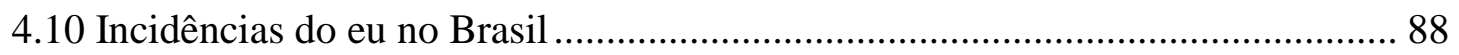

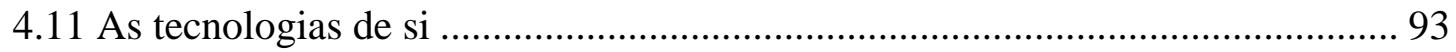

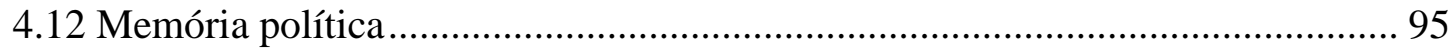

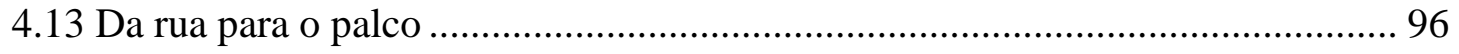

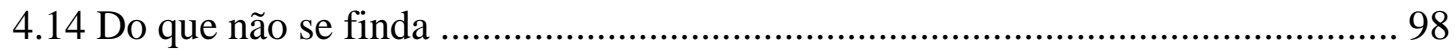

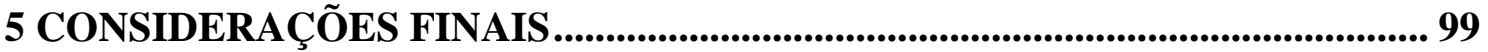

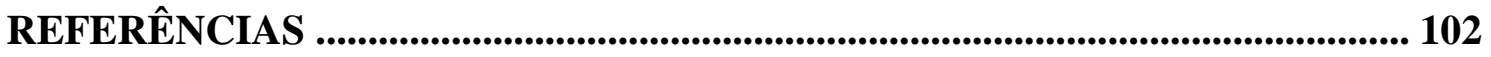

ANEXO A - Argentina / EBC ............................................................................................ 105

ANEXO B - Argentina / Estadão ...................................................................................... 106

ANEXO C - Argentina / Clarín em Português............................................................... 107

ANEXO D - Argentina / Blog Anistia ........................................................................... 108

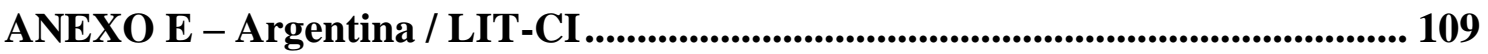

ANEXO F - Argentina / Justificando .................................................................... 110 


\section{INTRODUÇÃO}

Ao visitar materiais de cunho autobiográfico, seja como mote artístico ou escritural, percorremos diversas estruturas que despontam seminalmente nos debates em torno da literatura. É, a partir das correntes da teoria literária que nos debruçamos sobre o vasto campo de estudos acerca das poéticas de si como atrativo para as mulheres, na crítica aos modelos sociais que as envolviam. O espaço de circulação e atuação amplamente debatido no campo literário se abre, tensionado por elas, para discutir, na vertente artística, a ausência delas nos espaços e representações autorais, revelando uma fratura social. As políticas da diferença enveredadas pela percepção da ausência das mulheres em diversos espaços sociais, inclusive em condições de desigualdade trabalhista - trouxeram avanços a partir das correntes feministas, que tanto somam nas políticas públicas e protestos de resistência. Desobediência, potência política, interseção entre privado e público, subalternidade dissonante, dissidência, ato político ${ }^{1}$ são alguns pontos que atravessam a autobiografia, não apenas como gênero literário, mas na friç̧ão com a categoria mulher e também na fronteira que borra as manifestações artísticas.

Desta forma, não nos pautamos em fazer uma análise crítica das relações de gênero, mas, por meio da escrita performativa latina ${ }^{2}$, objetivamos ressaltar o percurso das estratégias encontradas por elas (escritoras, artistas e muitas que ousaram relatar seus incômodos) da casa para a rua e, mais tarde, na arte, como manejos de existir e firmar-se in loco, através de artifícios de resistência encontrados nos protestos, durante a organização delas em um olhar para a rua. E, neste aspecto, concordamos com Figueiredo (2013), ao entender que as questões atreladas ao gênero exigem aspectos e conteúdos mais profícuos, demandando apuro e análise das relações estruturais e sistêmicas. Assim, deixamos para pesquisadoras do campo da crítica social, que podem, por via de material mais recente, contribuir com visão sociocrítica mais apurada. Para tanto, destacamos Margareth Rago, pesquisadora e professora da Universidade Estadual de Campinas (Unicamp), por sua contribuição mais recente sobre feminismos, crise

\footnotetext{
${ }^{1}$ Entendemos o termo a partir do que Hannah Arendt define: política como liberdade e participação ativa de todos na garantia da convivência por meio das diferenças. Cf. ARENDT, Hannah. O que é política. Rio de Janeiro: Bertand Brasil, 2011.

${ }^{2}$ Referimo-nos à escrita performativa latina, depois que a pesquisadora realizou, na cidade de São Paulo, uma ação performática com a artista Maria Galindo (Bolívia), em 2018. Na ocasião, Galindo, compartilhou as dificuldades que temos em cruzar os acontecimentos das mulheres latinas com fatos ocorridos e narrados pela História (corpus ocidental). Segundo a artista, nos foi negado simultaneidade na escrita da história e nossa reflexão sociocrítica ainda sofre deste sintoma.
} 
da democracia e neoliberalismo ${ }^{3}$. A autora alerta para os desafios deixados pelos processos de emancipação colocados pelos feminismos ${ }^{4}$ que postulam um regime de verdade defensor da autonomia de si (neoliberalismo). Neste aspecto, pontua uma rede de ação e reflexão sobre a investigação das técnicas de si, práticas culturais, artísticas e mobilização sociopolítica, que vão pensar, com urgência, as possíveis ações contra a normalização destes agentes nos feminismos transnacionais ${ }^{5}$. Assim, pautamo-nos em trazer ações artísticas e estratégia de mulheres, mirando as atividades realizadas durante as ações sociais que ocorrem nos movimentos de protesto, em especial nos movimentos ocorridos na Argentina. Depois, olhamos para o Brasil, visando seus desdobramentos e influências nos processos de emancipação da mulher.

As pistas deixadas pela autobiografia das mulheres trouxeram temas fortes, que também foram refletidos em ações artísticas e em autoperformances ${ }^{6}$, dando vazão à problematização de temas de rechaço social: Aids, estética vaginal, determinismo biológico, colonialidade; além de carregar consigo experimentos de estéticas radicais trazidas pelas mulheres em seu fazer. Nesse sentido, não exemplificamos performances artísticas genuinamente autobiográficas ${ }^{7}$, mas aquelas com vestígios da relação entre arte e vida, a partir da perspectiva de que a mulher e sua autobiografia dão margem para diversos dispositivos $^{8}$ de criação vistos com muita força na cena contemporânea ${ }^{9}$. Assim, deslocamo-

3 Disponível em: https://www.encontro2018.sp.anpuh.org/simposio/view?ID_SIMPOSIO=19. Acesso em: 31/07/2018.

${ }^{4}$ Optamos por inserir feminismo no plural, respeitando os diversos seguimentos gerados a partir da luta das mulheres. Sua pluralidade: feminismo negro, indígena, radical, islâmico, liberal, trans, interseccional etc.

${ }^{5}$ Apresentado por Abu-Lughod como crítica universalista que coloca as mulheres como vítimas a serem salvas. Ela pontua que as feministas devem entender as mulheres que atuam na colisão. Cf. ABU-LUGHOD, Lila. Do Muslim Women Need Saving?. Massachusetts: Harvard University Press, 2013.

${ }^{6}$ Cf. KIRBY, Michael. An Introduction, The Drama Review: TDR, Vol. 23, No. 1, Autoperformance Issue (March, 1979).

${ }^{7}$ Neste aspecto, inserimos o corpo como material que visa discutir as relações de poder como gerador das manifestações autobiográficas.

8 A palavra "dispositivo" segue a hipótese de Agamben (2015), a partir da estratégia de Foucault (1970), na denominação de governabilidade ou de governo dos homens. Neste sentido, o dispositivo é uma rede que estabelece um conjunto heterógeno que está contido nos discursos, estruturas arquitetônicas, enunciados científicos, instituições, proposições filosóficas etc. De cunho estratégico, o dispositivo está inscrito num jogo de poder e resulta do cruzamento das relações de poder e das relações de saber. Ao abandonar o contexto foucaultiano, Agamben apresenta uma divisão de dois grandes grupos ou classes: os seres viventes e os dispositivos que estão incessantemente capturados. Chama, assim, de dispositivo, qualquer coisa que possua, de algum modo, a possibilidade de capturar, determinar, interceptar, orientar, modelar, controlar e assegurar os gestos, opiniões, condutas dos seres viventes. Denominando não somente as escolas, as confissões, fábricas, os manicômios, que de certa forma o poder já é evidente, mas a caneta, a literatura, escritura, filosofia, navegação, agricultura, computadores, celulares e a própria linguagem (talvez, segundo Agamben, o dispositivo mais antigo). Um terceiro desdobramento, a partir desses dois, seria o sujeito que resulta da relação do corpo a corpo entre viventes e dispositivos, estando em um processo de subjetivação. A estrutura raiz do dispositivo se apresenta no desejo humano de felicidade, que constitui potência específica do dispositivo. Desta forma, quanto mais os dispositivos se disseminam, mais se tornam inapreensíveis. 
nos para o Cone Sul, mesmo entendendo que outras artistas da Europa e América do Norte já radicalizavam e utilizavam aparatos tecnológicos (fotografia e vídeo), para ampliar os debates da categoria mulher.

Ainda refletindo com Rago, buscamos processos ocorridos na América Latina e obras artísticas exemplares no contexto (Cone Sul), além de necessidades que atravessam a ótica transnacional (Argentina/Brasil), não esquecendo as influências deixadas pelas ditaduras sangrentas nos países latinos - modelos enrijecidos pela normatização do corpo das mulheres - e sistemas punitivos que envolvem corpos à margem do que é aceitável pelos parâmetros dos sistemas hegemônicos ${ }^{10}$. Realizamos essa busca, entendendo os arranjos de força e resistência diante das atrocidades ocorridas desde a colonização, bem como construindo o diagnóstico das estratégias que se apresentam por intermédio da singularidade autobiográfica e se derramam no coletivo de maneira arguta. É na zona fronteiriça entre arte e vida que as mulheres acentuam nos movimentos de protesto, por meio das dores e mazelas oriundas dos sistemas punitivos. E, como não poderíamos deixar de ressaltar, abordamos a luta mais recente que tem elevado os debates sobre o corpo da mulher: a descriminalização do aborto como política pública. Isto, além de outros temas, tem ampliado o uso da autobiografia nos movimentos de protesto sociais, como exemplo de discussão a partir da organização e da ação que sustentam avanços na relação entre corpo e Estado.

\footnotetext{
${ }^{9}$ Assim como é comumente utilizado no meio teatral, nesta pesquisa, denominamos cena contemporânea como não anônimo de campo teatral definido, a partir do conceito sociológico de Pierre Bourdieu.

${ }^{10}$ Apoiamo-nos no que Gramsci expôs como dominação de um grupo em relação às classes subalternas.
} 


\title{
2 PISTAS E APROXIMAÇÕES DA AUTOBIOGRAFIA
}

\author{
2.1 A morte da autora e a escrita de si
}

Nada é mais difícil do que escrever uma autobiografia.

(Alexandra Kollontai)

\begin{abstract}
$* * *$
As mulheres não escrevem livros sobre os homens - fato que não pude deixar de acolher com alívio, pois, se tivesse que ler primeiro tudo o que os homens escreveram sobre as mulheres e, depois, tudo o que as mulheres escreveram sobre os homens, o aloés que floresce uma vez a cada cem anos floresceria duas vezes antes que eu pusesse a pena no papel.
\end{abstract}

(Vírginia Woolf)

Em A morte do autor (1968), Barthes propõe falar da neutralidade e, para isso, elucida Balzac (1799-1850) sobre ideias de feminilidade. Segundo o autor a escritura é neutra, perdese o corpo e a identidade. Num exercício de apagamento de si, perda da voz e sua funesta abdicação de ser, nasce a escrita. Sua visão acentua que o autor é personagem moderna produzida na sociedade que prima pelo indivíduo. Defende que a linguagem deve falar e que a escrita deve ser uma impessoalidade prévia: “[...] só a linguagem age, 'performa', e não 'eu'” (BARTHES, 2004, p. 59).

A crítica de valoração entre obra e autor, proposta por Barthes, é producente numa sociedade em que escrever e ter acesso à fruição de escritas era privilégio classista e de gênero. $\mathrm{O}$ apontamento propõe desmembramento do autor frente a sua obra, distanciamento narcísico pertinente à visão crítica, e atenua a ideia de performativo numa categoria de algo raro, não obstante volta para o sentido de valoração da qual tinha se distanciado ao propor o apagamento do autor.

No entanto, seu célebre manifesto desagradou a crítica feminista, porque, neste momento, as mulheres avançavam frente aos espaços autorais; mesmo com o estruturalismo barthesiano, a crítica feminista levantava a visão sociocultural, numa tentativa de escrever obras literárias por meio da visão sociocrítica. 
Depois dele, e em outra concepção seminal, Michel Foucault, em seu ensaio $O$ que é um Autor? (1969), conceitua o termo a escrita de si e nos apresenta indícios conceituais sobre autobiografia. No início do ensaio, é notável a relação do autor com a escrita, as ações do pensamento e a relação do indivíduo com documentos pessoais. A anacorese ${ }^{11}$ estaria atrelada à prática cristã, documentada por Atanásio no texto Vita Antonii, "um dos mais antigos que a literatura cristã nos teria deixado" (FOUCAULT, 2009, p. 131) como possibilidade de afastarse, pois a presença do outro poderia provocar certo constrangimento ao eu lírico. No entanto, este distanciamento não tornaria a pessoa invisível, apenas distanciada de qualquer olhar que colocasse sua escrita pessoal à vista dos outros. A prática solitária de escrever e refletir, mesmo em meio a uma multidão, estaria ligada a um exercício de foco em combate à alienação.

Outro disparador é o confessionário ${ }^{12}$. Foucault vai esmiuçar melhor no livro $A$ História da Sexualidade: A vontade de Saber (1976) que, no ensaio, a escrita está na ordem dos "movimentos internos da alma" (FOUCAULT, 2009, p. 132), aproximando-se da confissão ao leitor. A escrita de si também se alinhava, segundo Foucault, ao exercício do pensamento. A elaboração de um discurso tido como verdadeiro atuava de forma linear e de forma circular. Em ambas, a intenção de elaborar um discurso verdadeiro participava dessas duas formas. Sobre isso, o autor ressalta:

Como elemento do treino de si, a escrita tem, para utilizar uma expressão que se encontra em Plutarco, uma função etopoiética: é um operador da transformação da verdade em ethos.

Esta escrita etopoiética, tal como surge através dos documentos do I e do II séculos, parece ter-se estabelecido no exterior de duas formas já conhecidas e utilizadas com outros fins: os hypomnemata e a correspondência (FOUCAULT, 2009, p. 134).

Embora o olhar do autor em relação ao hypomnemata seja para anotações relacionadas à contabilidade, a ação de relatar por meio da escrita traça um guia de conduta. As escritas abrem para citações, testemunhos e reflexões ouvidas e, através dela, aguçam a memória do escritor/leitor, definida como "memória material das coisas lidas" (FOUCAULT, 2009, p. 135). Vale lembrar que o hypomnemata não é a narrativa de si, mas a ligação dos julgamentos da moral e da ética, tendo, como objetivo, a conexão consigo mesmo: "recolecção do logos"

\footnotetext{
${ }^{11} \mathrm{O}$ que mais tarde vai dar vazão às Técnicas de Si, conceito desenvolvido por Foucault em $\mathrm{O}$ cuidado de Si (1984).

${ }^{12} \mathrm{O}$ ato de confessar também pode ser visto em Rousseau, em seu livro Confissões (1786).
} 
(FOUCAULT, 2009, p. 138). Sobre a correspondência, o filósofo vai citar os cadernos de notas como exercícios de escrita pessoal, servindo para ser enviado a outros.

Segundo Figueiredo (2013), tanto Foucault quanto Barthes deslocaram a função do autor como detentor do sentido e origem do texto, propondo colocar o texto em circulação, na medida em que também esvaziavam a carga psicológica da crítica biográfica. Em contrapartida, o projeto intelectual feminista reivindicava o lugar das escritoras e o combate à ideia androcêntrica, ao passo que este deslocamento do autor se configurava no desfalecimento da autoria e colidia com a reivindicação política de autoria proposto pelas autoras para sua congênere feminista. A tentativa de Barthes de universalizar a concepção autoral não levava em consideração a desigualdade de homens e mulheres, dado que, segundo Nancy Miller (1988), não foram atribuídas a autoria pelo fato de que as mulheres estavam em posição incipiente (apud SOUSA, 2016, p. 128). Assim, as implicações políticas pesaram para as mulheres que estavam em processo de alcançar espaço de autoria e prematuramente foram limadas deste estágio embrionário.

As chamadas queixas, apresentadas por diversas autoras, ganharam amplitude ao romper o espaço da casa para a rua. Estas questões permeiam obras de Virginia Woolf, tais como Ao farol (1927), Um teto todo seu (1929) e, antes dela, O papel de parede amarelo (1892), de Charlotte Perkins Gilman, traziam para o leitor indícios do autobiográfico em uma sociedade marcada pela escrita masculinista. Em Um teto todo seu, Woolf debate a questão do tempo dedicado ao oficio da escrita nas funções destinadas às mulheres e questiona, a partir destas implicações, gênero e trabalho.

Mais do que queixas, o ato de escrever é tido como resistência, luta e desobediência aos modelos sociais. As confissões da escritora silenciada ganharam força na tinta sobre o papel, num corpo transformado em quimera. Ainda em Um teto todo seu, Woolf retrata as responsabilidades sociais e a dependência financeira que as mulheres tinham em seus casamentos, e declara que só se dedicou à leitura e à escrita graças a uma herança que recebeu de uma tia distante. Teríamos mais autoras e artistas se as mulheres tivessem mais tempo e situação financeira favorável? O ponto nevrálgico da obra é a questão financeira e o poder e, neste contexto, reconhece as estruturas, sistemas e agenciamentos que sustentam os personagens sociais ${ }^{13}$. Também pontua que as estruturas e sistemas rechaçam o trabalho, mesmo das mulheres imbuídas de boa situação financeira e com trabalhos exemplares.

\footnotetext{
${ }^{13}$ Neste contexto, tomamos como aporte o que Goffman vai tratar como atores sociais e o comportamento em grupo como representação de determinados códigos para convencer uma plateia. Cf. GOFFMAN, Erwing. A representação do eu na vida cotidiana. Petrópolis, Rio de Janeiro: Vozes, 2014.
} 
Através da personagem Judith, irmã fictícia de Willian Shakespeare, questiona implicações de gênero e trabalho e põe em questão a genialidade universal de Shakespeare. Visto que o tempo e a feitura de trabalho do homem diferem do das mulheres - infelizmente, são atribuídos a nós/elas o tempo dos serviços domésticos e, se não, a criação dos filhos e a responsabilidade familiar -, a autora descortina um contexto real e confessa que a mulher sempre existiu, na literatura, pela visão do homem.

Confessar também denota relação com a tradição cristã e, para Foucault, isto estaria ligado a uma técnica de si na construção da chave para o dispositivo de sexualidade ${ }^{14}$, e alerta que escrever para si e para outro foi uma conquista tardia. A ligação da tradição cristã também foi primordial, para Foucault, na construção do dispositivo de sexualidade, pois afirma que as sociedades ocidentais, a partir do cristianismo, atrelou o sexo à busca de verdade. Assim, a confissão e o exame de consciência se tornaram formas de colocar a sexualidade em voga, ou seja, só se referia à sexualidade no âmbito da proibição. O filósofo ataca as construções discursivas em torno da verdade e alerta para o caminho de repressão e miséria sexual. Para ele, o discurso se torna um instrumento de controle e poder e, muitas vezes, o objetivo deste discurso é desqualificar os movimentos de revolta e libertação.

No que tange à ideia do autor, Agamben (2008) alude à omissão de Foucault nas implicações éticas do sujeito. No livro A arqueologia do saber (2008), retoma alguns pontos do ensaio $O$ que é um autor?, numa tentativa de dar conta das consequências, acarretadas ao próprio sujeito, da dessubjetivação e da pulverização do autor, mas Agambem reforça que, somente em A vida dos homens infames (2006), Foucault apresenta a ideia de sujeito de outra forma. No prefácio, havia relatos de pessoas reais (mulheres e homens) condenadas pela justiça, mas esta versão não foi impressa e distribuída na edição em português (Brasil). Neste sentido, Foucault reconhece, nesses relatos, o deslocamento do anonimato, devido ao encontro com o poder na relação criminal com a Lei. Assim, os sujeitos do discurso, mesmo em seus relatos, não atuam como autores, pois, para Foucault, apresentam diferenças na linguagem (formal e informal) e, ao usarem a escrita para narrar suas mazelas, trazem, ao leitor, um rastro de emoção que arfa a vida (FOUCAULT apud FIGUEIREDO, 2013: 18-19).

Foucault elucida o gesto da escrita por meio de cartas - este recurso foi muito usado por mulheres numa chave autobiográfica - como dupla função, tanto para quem escreve como para quem lê, e a aproximação com o hypomnemata. Sobre isso, o autor ressalta:

\footnotetext{
${ }^{14}$ Em História da sexualidade I, II, II- que teve como base de ensaio a escrita de si, de Michel Foucault.
} 
A carta faz o escritor "presente" àquele a quem a dirige. E presente não apenas pelas informações que lhe dá acerca da sua vida, das suas atividades, dos seus sucessos e fracassos, das suas venturas ou infortúnios, presente de uma espécie de presença imediata e quase física (FOUCAULT, 2009, p. 149-150).

Vale lembrar que somente no Renascimento os trabalhos artísticos passam a exigir autoria, e isso aparece primeiro nas pinturas como condições do mercado da arte, mas logo é absorvido por outras linguagens artísticas. Baxandall ressalta a importância da pintura para estabelecer a manutenção das relações sociais. Poucas pessoas compravam obras artísticas, mas essas relações marcaram o século XV pela pintura sob encomenda (BAXANDALL, 1991, p. 15), designando duas variantes de ação: mecenas e clientes (BAXANDALL, 1991, p.11). Na medida em que as cores apareciam com facilidade no mercado e as técnicas de manipulação foram absorvidas, o deslocamento de valoração encontra, no autor, um olhar reflexivo do social, revelando o pensamento da sociedade na época.

Um contrato podia mesmo detalhar o que o cliente entendia por paisagens. Quando Ghirlandaio foi contratado em 1485 para pintar os afrescos para Giovanni Tornabuoni no coro Santa Maria Novella, em Florença, aceitou incluir "figuras, edifícios, castelos, cidades, montanhas, colinas, planícies, rochas, trajes, animais, pássaros e bestas de toda sorte". Tal demanda requeria uma profusão de trabalho, senão de habilidade (BAXANDALL, 1991, p. 28).

Na concepção de Barthes e Foucault, a presença não é a do autor, mas a ligação de vivacidade e envolvimento causada pela escrita. Neste sentido, o autor se torna um agente secundário, desaparecendo neste trânsito. Barthes propõe deixar que o acontecimento do leitor ou autor se dê na construção polissêmica da leitura e, para isso acontecer, segundo ele, o autor precisa desaparecer.

(...) o leitor é o espaço mesmo onde se inscrevem, sem que nenhuma se perca, todas as citações de que é feita uma escritura; a unidade do texto não está na sua origem, mas no seu destino, mas esse destino já não pode ser pessoal: o leitor é um homem sem história, sem biografia, sem psicologia; ele é apenas esse alguém que mantém reunidos em um mesmo campo todos os traços de que é constituído o escrito (BARTHES, 2004, p. 64).

Foucault e Barthes, calcados na linguagem, em paralelo aos estudos da contemporaneidade, abrem diversas questões. A partir dos debates pós-estruturalistas, póscoloniais e feministas, a representatividade e o lugar de fala ${ }^{15}$ se tornam recorrentes e, assim,

\footnotetext{
${ }^{15}$ Djamila Ribeiro defende, ao expor que podemos falar de diversos temas ligados a gênero e raça, pois o que está em questão não é o silenciamento de outros corpos, mas questionar autonomia em alguns seguimentos de
} 
esse alguém não seria um sujeito vazio e sem características, mas um sujeito construído socialmente.

\subsection{Confissões}

A partir dos indícios deixados pelos hypomnematas, com pistas e usos do eu, JeanJacques Rousseau, sob nova luz teórica a partir da escrita de si, abre as portas da ficção para a realidade, o que faz o crítico Costa Lima (1986) declarar que não há entendimento da escrita de si antes de Confissões (1782). Lima argumenta que o homem do século XVIII já apresentava noção de subjetividade (LIMA, 2015, p. 9) e, como autorreferencial moderno, Rosseau assume traços hegemônicos à obra. A iluminação teórica e sua nova égide se dão por meio do pacto autobiográfico apresentado pelo teórico literário Philippe Lejeune (1975), que caracterizou um modelo de escrita e leitura para analisar obras literárias autobiográficas.

A obra literária surgiu quando o autor constatou a ausência de pesquisas autobiográficas, numa tentativa de diagnosticar nuances entre o texto ficcional e o texto autobiográfico, sendo que ambos atendiam as mesmas leis. O texto autobiográfico se configura a partir da vida pessoal do autor e, para Lejeune, estabelece-se como "narrativa retrospectiva em prosa que uma pessoa real faz da sua própria existência” (LEJEUNE, 2014, p. 16), mesmo que, para isso, leve em consideração o contexto histórico, já que fazemos parte do mundo. A preocupação de Lejeune com o leitor em proporcionar indícios que distinguem o texto ficcional do texto autobiográfico configurou, na extensão do pacto autobiográfico, um vínculo entre leitor e autor que inferia no modo como se daria a leitura.

O pacto autobiográfico trata o compromisso do autor frente a um sistema de referência real para o leitor: dados como nome do autor na capa do livro e indícios dentro da narrativa são premissas deixadas pelo autor para selar o pacto. Um jogo estabelecido e acordado entre as duas partes. Mais tarde, Lejeune reelabora algumas questões referentes ao pacto autobiográfico, dando liberdade para o leitor se aproximar da leitura da maneira que quiser. No entanto, ao decidir ler, o leitor teria que selar um trato de reciprocidade, pois o autor estaria cedendo indícios reais, e o envolvimento seria um convite de comprometimento, mesmo que depois haja contestação ou negligência por parte do leitor. Por este ângulo, não pode haver ambiguidade, pois a preocupação de Lejeune com o pacto autobiográfico está na 
emissão e recepção. Desta forma, a mensagem não pode ser dúbia, ou seja, o leitor não pode ficar com dúvidas, porque "todas as análises são feitas a partir da recepção" (LEJEUNE, 2014, p. 94). O ponto de vista do leitor, através do pacto autobiográfico, deve ser trabalhado cautelosamente, para que não se quebre e o discurso de verdade não se cumpra.

O autor menciona que a palavra autobiográfica sofre, no final dos anos de 1970, flexão aos relatos de vida e, embora não cite Foucault, ressalta que por volta do ano de 1980 outras expressões, como escritas do eu ou escritas de si, surgem na tentativa de ampliar o campo, mas deixam o pacto numa função secundária. A transição do eu para o si, para Lejeune, apresenta pudor cristão, e o si se configuraria como algo mais altruísta.

A preocupação com o leitor aparece de forma estruturante na concepção do pacto autobiográfico, pois supõe uma "comunicação imediata ou diferida" (LEJEUNE, 2014, p. 96). Embora outros disparadores, como por exemplo o diário, possa trazer dúvidas sobre o pacto, ainda assim, escrever para si - mesmo que não seja explícito - prevê um destinatário, pois escrever para si é ainda fazer uso do recurso comunicacional; e, desta forma, o pacto é regido. Todavia, o autor ignora a distinção histórica de autoria entre homens e mulheres e, conforme Leigh Gilmore (1994) coloca, existe um esforço em manter a naturalização da autobiografia pela visão masculinista. A linhagem agostiniana, ainda segundo Gilmore, traça estudos tradicionais acerca da autobiografia e sua autorrepresentação na visão hegemônica do homem branco europeu e heterossexual.

As obras de Rousseau mantêm a hierarquia de identidades e reproduz classe, raça e gênero, enquanto tenta afirmar a diferença no campo crítico social de poder. Neste aspecto, Gilmore sustenta a legitimação taxonômica da autobiografia e detecta a exclusão do gênero feminino no legado da escrita de si, um processo excludente, que ignora as precariedades anunciativas das autoras impedidas de legitimidade, estabelecidas pelas restrições sociais e que, por vezes refugiadas pelo uso de pseudônimos e em publicações anônimas, tentavam ganhar espaço. Mas, não esquecendo que a assinatura trazia consigo a não identidade da mulher, já que muitas precisavam da autorização do marido, pois a ele pertencia, no mesmo peso que a propriedade. (GILMORE apud SOUSA, 2016, p. 129).

Gilmore parte da questão 'O que é o autobiográfico?', tomada pelo que as feministas questionam "O que são as mulheres?". Assim, a autobiografia estaria para um hibrido discursivo, com duas vertentes, pendular. Por um lado, a construção do eu como efeito de linguagem, construção textual e o que chamamos de identidade; por outro, um significado de experiências das mulheres que versam, por meio da crítica feminista, escritas 
autorrepresentacionais. A crítica da autora resvala na autobiografia calcada apenas em uma das duas versões. Toma nota de diversas autobiografias escritas por mulheres, na tentativa de encontrar um escopo teórico não único, mas que exemplifique a pluralidade da autorrepresentação como um conjunto de códigos múltiplos. Uma perspectiva de encontrar narrativas que exponham discursos de legitimidade em um espaço igualitário. Acrescenta que o assunto autobiográfico é produzido não pela experiência, mas pela biografia, e isso não reduz o autobiográfico, no entanto coloca como agente de produção autobiográfica. Neste sentido, as histórias que envolvem etnicidade, classe, sexualidade e gênero recaem no território da visão dominante com rechaço, reduzidas e criminalizadas desde seu início.

Embora Lejeune coloque a participação clandestina de alguns agentes como secretariados (fazedores, tintureiros, nègres), relate a questão do analfabetismo e do uso da memória popular por outros agentes (que não os próprios protagonistas), não avança nas questões e nem debate sobre a exclusão das mulheres no processo autoral. No contrafluxo, Gilmore opera na chave do espaço autobiográfico de mulheres, na perspectiva de um discurso múltiplo com ramificações de raça, classe, gênero, e acrescenta orientação sexual. Porém, concordamos com Butler (2010) e usaremos "prática sexual” ao invés de "orientação sexual". Assim, a necessidade de criar outra nomenclatura que atendesse às demandas das mulheres no processo de reconhecimento autoral fez com que Domna Stanton nomeasse autoginografia (autogynography) em seu ensaio polêmico Autogynography: Is the Subject Different? (1984), no intuito de criar um feminino para o gênero literário.

\subsection{Autoginografia}

A autobiografia, muitas vezes atribuída às implicações da biografia, denotava interferência direta da vida construída a partir dos sistemas dominantes. A reprodução compulsória de autorrepresentação ${ }^{16}$ que não se valesse da crítica colada à realidade vivida pelas mulheres não passava de uma narrativa construída pela visão hegemônica. Desta forma, a mudança terminológica proposta por Stanton (1984) se abria para o rearranjo do termo autobiográfico, tendo como aporte as transgressões da categoria mulher. A autora ignora bio,

\footnotetext{
${ }^{16}$ Atribuímos autorrepresentação ao que Ramos (2013) vai denominar como recusa ao binômio falsificação e verdade, em analise a este recurso dentro das obras fílmicas. In. RAMOS, Clara Leonel. A construção do personagem no documentário brasileiro contemporâneo: autorrepresentação, performance e estratégias narrativas. 2013. Tese (Doutorado em Meios e Processos Audiovisuais) - Escola de Comunicação e Artes, Universidade de São Paulo, 2013. Acesso em 31/07/2018.
} 
entendendo que o gênero é construído seguindo padrões hegemônicos determinantes; desta maneira, atribui gino, no sentido de firmar que as mulheres também escreviam e criavam narrativas por meio da autorrepresentação. A provocação da autora busca tensionar os espaços de criação, circulação e recepção das escritas de si, mesmo que esta tentativa se valesse do determinismo biológico numa episteme essencialista.

A necessidade de criar um cânone alternativo que atribuísse a dupla função do gênero, literário e sexual (genre/gender) ${ }^{17}$, e distinguisse a escrita das mulheres que se opunham à crítica social mascunilinista, reforçou a adoção da terminologia autoginografia. Mesmo com esforços, ao adentrarem o campo literário, a autobiografia/autoginografia, - considerada gênero nobre - foi rechaçada a gênero menor, a partir da participação das mulheres no século XX. Desta maneira, o gênero literário passa a ocupar o espaço periférico em que as narrativas do espaço doméstico e das concepções marginais operam na escrita feminina.

\subsection{A amplitude do gênero}

A partir da mesma premissa, Joan Scott (1989) conceitua gênero, distanciando do dualismo entre natureza (sexo) e cultura (gênero), ao concordar com Foucault na relação inseparável entre saber e poder. $\mathrm{O}$ uso do conceito de gênero clamava legitimidade aos estudos feministas, oferecendo meios de distinguir a prática sexual dos papeis atribuídos às mulheres e aos homens.

A autora divide gênero em duas partes e em várias subpartes. Nas duas divisões centrais, o gênero é elemento constitutivo e relação primeira em significar as relações de poder. Seu principal foco é combater a ideia de fixidade das categorias "mulher" e "homem", fazer a implosão da representação binária de permanência eterna e, para isso, a análise tende a incluir a noção do político como referência às instituições e organizações sociais.

Outro aspecto inclui a identidade subjetiva na qual o gênero estaria implicado na concepção e na construção do poder em si. Desta forma, não nega a existência de uma análise no tripé raça, classe e gênero, e uma construção histórica que amarraria esta tríplice. A grande

\footnotetext{
${ }^{17}$ A etimologia da palavra gênero no português (Brasil) aparece nas variáveis de gênero literário e sexual, sem alteração taxonômica, como na língua inglesa (genre/gender). Desta forma, compreendemos como adoção da nomenclatura no contexto feminista. Sua ambivalência no campo da teoria crítica feminista se pauta na categoria empírica de cada contexto. Cf. PISCITELLI, Adriana. Ambivalência sobre os conceitos de sexo e gênero na produção de algumas teóricas do feminismo In: Neuma Aguiar (org.) Gênero e Ciências Humanas: desafio às ciências desde a perspectiva das mulheres. Rio de Janeiro: Rosa dos Tempos, 1997.
} 
investida de Scott é a inversão da palavra "mulher" para "gênero", na medida em que a primeira implica a referência ao homem. A análise estanque poderia excluir a relação existente entre os sexos (feminino e masculino), ao passo que impediria as análises das relações de poder, ou seja, se um sexo não opera através do outro não existiria relação de poder e sabemos que as relações existem e pesam na construção social das mulheres, já que são vistas pela referência masculinista.

O gênero se coloca no desafio de ampliar a análise entre política e poder. Neste sentido, a abordagem da autora diagnostica a explicação das feministas americanas em relação ao patriarcado, estabelecendo o marxismo como ferramenta de compromisso e a psicanálise como reprodução da identidade subjetiva de gênero. Em uma das afirmações, a autora coloca que "a história política foi encenada no terreno do gênero. É um terreno que parece fixado, mas cujo sentido é contestado e flutuante" (SCOTT, 1989, p. 28); desta forma, o gênero, em diversas análises, torna-se estruturante aos debates e nos espaços de autoria, autorrepresentação, autobiografia e, em nosso foco, nas manifestações artísticas.

Entendendo as colocações de Scott, e antes dela Rubin ${ }^{18}(1975)$, sobre a conceituação de gênero, propomos como recorte o uso da categoria mulher (mas não excluímos gênero), distantes das ideias do feminismo radical (1970) e do essencialismo, na medida em que concordamos com a conceituação do fundacionalismo biológico, defendido por Linda Nicholson (2000). Na conceituação, a autora pontua a importância de não confundí-lo com determinismo biológico, uma vez que este se relaciona com a biologia, no sentido de personalidade e comportamento, e o fundacionalismo biológico acopla as informações da biologia em coexistência (personalidade e comportamento), mas de forma acidental. Assim, a identidade sexual não é entendida puramente fisiológica, ao mesmo tempo que o fundacionalismo, para a autora, propõe a ideia incompleta ao debate da identidade sexual. Exemplifica a ideia de "porta casacos" (NICHOLSON, 2000, p. 14) na posição das diferenças das mulheres em um sentido de coexistência, entendendo as ramificações, pluralidades e colisões presentes na raça e classe.

O que estou chamando de 'fundacionalismo biológico', mais do que uma posição única, pode ser entendido como representante de um leque de posições, unidas de um lado por um determinismo biológico estrito, de outro por um 'construcionismo social' total. Uma vantagem de se ver o 'fundacionalismo biológico' como representante de um leque de posições é que assim ele se opõe à tendência comum de se considerar as posições do 'construcionismo social' iguais em relação ao papel que a biologia nelas

${ }^{18}$ RUBIN, Gayle. Políticas do sexo. São Paulo: Ubu Editora, 2017. 
representa. As feministas da segunda fase frequentemente assumiram que basta reconhecer qualquer distância em relação ao determinismo biológico para se evitar todos os problemas associados a essa posição. A questão, porém, é bem mais relativa: as posições da segunda fase mostraram-se a distâncias maiores ou menores do determinismo biológico, mas também mostraram um maior número de problemas associados a essa posição, de acordo com a distância tomada- falo especificamente da tendência a produzir generalizações equivocadas a partir de projeções do contexto cultural da própria teórica.

A possibilidade de ser 'mais ou menos' construcionista social é consequência do argumento de que qualquer fenômeno pode ser considerado como contribuindo 'mais ou menos' para um determinado resultado. Normalmente falamos de determinismo biológico quando um fenômeno especifico é considerado inteiramente como consequência de fatores biológicos. Assim, ser um construcionista social é meramente argumentar que a sociedade teve alguma participação num determinado resultado (NICHOLSON, 2000, p. 23).

A ideia da autora ainda mantém a distinção entre homens e mulheres, de forma parecida como acontece em diversas culturas, mas acrescenta, na formulação e no entendimento de mulher, atenção à historicidade, investindo na rede complexa de características não descobertas ou ignoradas pelas feministas brancas. Desta forma, o pensamento de mulher se apresenta na fronteira borrada que não se resume na relação genital e útero, mas coloca outros corpos como intervenção política da diferença acoplada à tal categoria. Tenta dar conta das diversas segmentações feministas, visto que a afirmação da diferença em relação ao homem é uma relação histórica de diferenciação ${ }^{19}$ e pode ser usada estrategicamente como luta emancipatória, mas não exclui grupos e subgrupos que atuam no pensamento e estratégias de colisão. Como se sabe, houve uma exportação do feminismo americano e europeu - que muito contribuiu para o pensamento emancipatório - aos países da América Latina que tentavam, numa mesma linha temporal, dar conta das sangrentas ditaduras vividas em seus países. E, hoje, no Brasil, buscam-se alternativas que melhor atendam às necessidades e pautas referentes às mulheres brasileiras em suas pluralidades e anseios. Mesmo nos Estados Unidos, Angela Davis (militante, ativista, negra e filósofa) contrapôs o feminismo classe-média, predominante no país, com o debate em torno do feminismo negro; este e o feminismo britânico, com cerne na luta operaria, ainda se ausentam estruturalmente nas lutas latinas.

Nicholson expõe que as feministas buscam olhar pautas relacionadas aos seus grupos de atuação e que sua fratura se dá porque as mulheres de direita e trans, por exemplo, são destituídas dessas pautas, ao passo que também são vitimadas. Defende, que não podem ser

${ }^{19}$ BOURDIEU, Pierre. A dominação masculina. Rio de Janeiro: Best Bolso, 2016. 
deixadas para trás, pelo fato de apresentarem outras pautas que, por vezes, diferem ou contradizem alguns grupos feministas. Desta forma, argumenta:

Assim, sugiro pensarmos o sentido de 'mulher' como capaz de ilustrar o mapa de semelhanças e diferenças que se cruzam. Nesse mapa o corpo não desaparece; ele se torna uma variável histórica especifica cujo sentido e importância são reconhecidos como potencialmente diferentes em contextos históricos variáveis. Essa sugestão, desde que se assuma que o sentido é encontrado, não pressuposto, assume também que a procura em si não é um projeto político ou de pesquisa que uma intelectual será capaz de executar sozinha em seu gabinete. Ele implica, na verdade, uma compreensão desse projeto como esforço necessariamente coletivo a ser feito por muitas, e em constante diálogo (NICHOLSON, 2000, p.39).

Neste sentido, a proposta de reelaboração da categoria mulher é, acima de tudo, política. Nicholson reafirma que a categoria mulher tem dupla vantagem: o reconhecimento de diferenças que não anula a possibilidade de mapear as semelhanças e acolhe as políticas de coalisão referentes às diferentes pautas e necessidade de grupos e subgrupos (NICHOLSON apud PISCITELLI, 2002, p. 36). Assim, as diferenças derivam das metas de articulação política, e as modificações referentes à taxonomia, que tanto Nilcholson como Stanton propõem - autoginografia e mulher (categoria) -, não carregam em si unidade, as mudanças não causam consenso, mas tentam trazer as implicadas para pautas que convirjam interesses em comum, mesmo em caráter temporário.

Acolhe, desta forma, o lugar de fala e a representatividade baseada no lugar que ocupa o corpo na história e na cultura, tidos como atos políticos que reforçam o social de luta dentro de contextos múltiplos, e nos anseios que cada corpo busca almejar. Para tanto, pressupõe interesse e compreensão das mulheres não em uma articulação fácil de ser ajustada, mas na aposta da colisão de diferentes reinvindicações em torno de grupos que convergem e divergem. A compreensão da autora do enfraquecimento coeso das lutas feministas e a aproximação das políticas da subjetividade ${ }^{20}$ exigem maior cuidado. Ao invés de excluir, seria necessário buscar formas possíveis de diálogo, em que as mulheres possam atuar em conjunto e os outros grupos possam estar neste campo de atuação. Entretanto, para isso, é necessário um ajuste temporal político-social que insista no acolhimento da diferença, mesmo em colisão.

\footnotetext{
${ }^{20}$ RAGO, Margareth. Feminismo e subjetividade em tempos pós-modernos. In: LIMA, C.C.; SCHMIT, S.P. (Orgs.). Poéticas políticas feministas. Florianópolis: Editora das Mulheres, 2004. p. 31-41.
} 


\section{$2.5 \mathrm{O}$ relato de si}

Os diversos desdobramentos da autobiografia, seja por meio da mudança taxonômica (autoginografia) ou por via da autorrepresentação, escrita de si, autoescritura ${ }^{21}$ ou autonarrativa, trazem consigo o diagnóstico da necessidade de falar. A ideia de divã expandido denota não apenas um local de relação entre locutora e o/os interlocutora/e/or, mas uma condição de interpelação como possibilidade de reflexão de si. Ao contar a história pessoal, a memória passa a ser o principal ativador dessa lembrança.

Para Klinger (2012), no Brasil, Argentina e Chile, as práticas culturais e literárias de romances memorialistas continuam atuantes, desde os anos de 1980, sobre as ditaduras militares, e persistem depois do retorno da democracia, pois a recuperação da memória se faz na luta contra a alienação. A inversão da escrita de si no período pós-ditadura difere do século XIX e do modernismo e, desta forma, a memória não preserva os valores de classe, mas atua na força contrária de sinalizar mudanças de valores de geração numa "restauração da memória coletiva" (KLINGER, 2012, p. 21). Ao falar de si, a dupla conexão (locutora/interlocutora) ou “duplo valor ético" (BUTLER, 2015) denota reconstrução dentro do vivido e atuação dentro deste processo. $\mathrm{O}$ ato de falar de si reconstrói temporalidades, reforça o vivido e rechaça as violências veladas e naturalizadas pela moralidade geracional.

Butler (2015), com base em Foucault, incita que, ao dizer algo, não precisamos dizer a verdade, e isso não deve ser visto como ilusão. $\mathrm{O}$ ato de falar torna o sujeito público num processo de se fazer ver para o outro. "A confissão torna-se a cena verbal e corporal da demonstração de si mesmo (...) Ela se fala, mas na fala torna-se o que é” (BUTLER, 2015, p. 145). Foucault, ressalta que não precisamos de bases históricas da própria vida, mas posição autocrítica. Sua construção e postura crítica trazem contraposição dos sistemas de regulação e códigos de conduta que modelam e formam os sujeitos. Tal enfrentamento aos códigos e sistemas regulatórios abrigam exclusões que comprometem o reconhecimento de outros. A prática de externar é a forma de tornar-se público. Assim, todo ato de confissão que pressupõe infração, violência ou ação que exceda a Lei só se torna socialmente constituído quando exibe a manifestação dada por meio da confissão. Desta forma, Foucault, para Butler (2015), acentua que a confissão acontece através do "ato de sacrifício" (BUTLER, 2015, p. 147). Na presente formulação, a manifestação da verdade só ocorre quando o ato de desaparecimento destrói o corpo e a existência real do sujeito. Assim, as relações e modos de reflexividade são

\footnotetext{
${ }^{21}$ LEITE, Janaina Fontes. Autoescrituras performativas: do diário à cena. São Paulo: Perspectiva, 2017.
} 
dadas pela ação social e ética e, insiste que a relação consigo mesmo é "social e pública" (BUTLER, 2015, p. 147). O risco de revelar-se, nesse caráter de verdade, pode acarretar inteligibilidade aos outros, mesmo que o ato de desapossar de si abra para a constituição do sujeito no tempo. Na construção da fala de si, a constituição pode descrever uma situação punitiva e moral, como também pode trazer à tona personagens sociais que atuam no regime das forças e por meio do poder, da ética e da moral sobre outros. Tanto Butler como Klinger trazem o narcisismo como sintoma deste falar de si apoiados pelos modos do individualismo e recursos midiáticos contemporâneos, mas também reforçam como estamos sendo formados na vida social. Butler chama à responsabilidade ética da seguinte maneira:

Talvez seja ainda mais importante reconhecer que a ética requer que nos arrisquemos precisamente nos momentos de desconhecimento, quando aquilo que nos forma diverge do que está diante de nós, quando nossa disposição para nós desfazer em relação aos outros constitui nossa chance de nos tornarmos humanos. Sermos desfeitos pelo outro é uma necessidade primária, uma angústia, sem dúvida, mas também de sermos movidos, impelidos a agir, interpelamos a nós mesmos em outro lugar e, assim, abandonar o 'eu' autossuficiente como um tipo de posse. Se falarmos e tentamos fazer um relato de nós mesmos a partir desse lugar, não seremos irresponsáveis, ou, se o formos, certamente seremos perdoados (BUTLER, 2015, p. 171).

A filósofa lança a ideia da responsabilização, mesmo que isso traga vulnerabilidade às "desapossadas", revelando, através da vulnerabilidade social e civil, "modos de sujeição" (SAFATLE In BUTLER, 2015, p. 185). A fuga deste relato de verdade ou o ato de desapossar pode trazer tensão do real vivido e narrado por intermédio de recursos que tensionam a autobiografia. Neste sentido, a imbricação com a autoficção tenta dar conta desta ausência de elementos que constituem uma verdade a ser ouvida, narrada ou descrita. Mas será que a autobiografia nunca fez uso de tal recurso, mesmo assumindo o pacto de verdade? Ou as mulheres, para falar de suas submissões e violências, tiveram que fazer uso, numa brincadeira de revelar e ocultar, das tensões do autobiográfico com o autoficcional para serem aceitas, mesmo com percalços, em um regime de construção de espaço social e de trabalho? Seria muito difícil, socialmente, aceitar que nem todas as mulheres encontram prazer nas relações domésticas, servil e casamenteira? Seria necessário, para isso, algumas facetas? Afinal, a autobiografia servia a quem? E o autoficcional traria a estetização necessária para situações tão adversas à sociedade? Para falar algo concernente às mulheres, seria necessário utilizar a autobiografia atrelada à autoficção?

Que estratégias as mulheres criaram nas premissas do dizer? 


\subsection{Autoficcional}

Segundo Figueiredo (2013), o termo autoficção foi cunhado por Serge Doubrovsky (1977) depois de ter contato com a obra de Philippe Lejeune, O pacto autobiografico. O autor perguntava sobre a possibilidade de escrever romance em que o protagonista-narrador levasse o mesmo nome do autor. Para ele, autoficção se contrapõe à autobiografia clássica ${ }^{22}$ e, neste cruzamento, podemos analisar as estratégias autobiográficas das mulheres, em diálogo com a problemática da ausência das autoras, detectando fragilidade autoral, (não) lugar na História e suas formas encontradas para falar. Assim, os grandes feitos da autobiografia clássica dão lugar a algo menor, sem importância, coisa pequena e miúda, a voz e escrita das mulheres. A autora pontua que a crítica masculinista francesa tem demonstrado desprezo pelo autobiográfico, alegando que o gênero (literário) pertence ao domínio feminino.

A constante preocupação de não ficar nas coisas de mulherzinha, como se a dicotomia homens e mulheres pudesse ser universalizante e o gênero (masculino/ feminino) algo irrelevante na construção social. A crítica francesa não só detecta como coloca a autobiografia de mulheres como algo menor, desqualificando qualquer tipo de necessidade dessas escritoras na conjuntura das relações sociais. Para tanto, a fala, a escrita e a arte (delas) se tornam provocação e resistência. Relatando fragmentos de exclusão da realidade social, para além de um indivíduo. Uma denúncia, uma provocação, para que o social tome nota e seja forçado a pensar a respeito.

Bakhtin (2015) vai diferenciar a autobiografia da autoficção, definindo a última como um ato literário que a estetização e o comprometimento com o belo e o fantasioso colocam próximo a um plano artístico. Embora o contexto artístico do autor não seja o mesmo que utilizamos, cabe entender que ele propõe plano artístico no sentido de valoração. E acrescenta que a autoficção acontece quando o autor usa recursos ficcionais colados à sua biografia para trazer comoção ao leitor.

Doubrovsky pontua que a escrita no presente seria uma tarefa impossível e a narrativa do passado e memórias atreladas à infância são inexistentes, pois a infância não tem história (DOUBROVSKY, 1977 apud FIGUEIREDO, 2013, p. 70). Acrescenta ainda que sua

\footnotetext{
22 Figueiredo (2013) expõe que autobiografia clássica estaria ligado ao renome, ou seja, à fama, que ao fim da vida levaria o autor a escrever suas experiências pessoais. Evidente que, a partir dessas escolhas, muitos personagens sociais narrados nas obras literárias seriam esquecidos ou reformulados pelos autores.
} 
dificuldade estaria em dizer a verdade ao escrever sua autoficção. Assim, a autoficção presentifica o passado, e as memórias vividas e contadas no presente poderiam ser (re)criadas conforme o interesse do autor. O pacto com a verdade dos fatos experienciados não se firma na autoficção, e se caracteriza pela marca da ambiguidade. Talvez a autoficção seja a vertente que mais se aproxime das linguagens artísticas ou que mais atenda às demandas e campos relacionados à arte. Será mesmo?

\subsection{Autoficção das mulheres}

A autoficção para a categoria mulher pretendia alçar estratégias que denunciassem as atrocidades naturalizadas por intermédio da visão sociocrítica. Uma possibilidade de potência para discutir os agenciadores que operam no corpo da mulher, que agem nas políticas do corpo, liberdade e determinismo biológico, impedindo possibilidade de fluidez dos desejos e necessidades de cada mulher. Além do abandono ao uso de pseudônimos para dizer assuntos de rechaço e problemas sociais. Sobre o autoficcional relacionado à categoria mulher, Figueiredo aponta:

É graças à possibilidade de criar um duplo de si que as escritoras podem expor-se, com seu próprio nome, nessas autoficções, desvelando, assuntos tabus como incesto e prostituição ou explorando temas como lesbianismo, desdobramento esquizoide ou paranoico, porque a autoficção não tem compromisso com a verdade, ela é uma ficção que se inspira e joga, livremente, com os biografemas. Ao mesmo tempo, deve-se destacar que a escrita feminina sobre a sexualidade, em particular, e sobre o corpo e a identidade feminina, em geral, se propõe a fazer uma releitura do papel arcaico da mulher, que é a de ser objeto do desejo do homem e, por isso, às vezes faz alusão, por exemplo, aos grandes mitos da feminilidade criados pelos contos de fadas como Cinderela, a Bela Adormecida, Chapeuzinho Vermelho. O que faz a diferença é que, numa sociedade permissiva, as escritoras narrativizando suas próprias vidas, exibindo uma sexualidade que, longe de ser bem resolvida e prazerosa, parece ser ainda bastante problemática (FIGUEIREDO, 2013, p. 73).

Os temas que atravessam a autoficção não apresentam narrativas felizes; pelo contrário, os temas envolvem situações de dor e incômodo. Percorrem os tabus sociais que, por estarem inseridos na ficção, são melhores absorvidos pelos leitores ou espectadores. No que tange às mulheres, as narrativas envolvem situações de violência, responsabilidades maternais, dor, desprazer, assédio, estupro e falência de amor, racismo, misoginia, amor 
lésbico (...). Tais abordagens tendem a ser recorrentes na autobiografia e em seu desdobramento: a autoficção. A máscara da autoficção pode dar uma falsa sensação de liberdade ao expor assuntos que algumas mulheres não conseguem lidar, pois trata o uso da linguagem como instrumento, seja para dar voz às mulheres ou para rechaçar a naturalização dada sobre a ótica masculinista determinista.

Embora perspicaz, esta estratégia parece contrariar o pacto autobiográfico no rompimento com o real. Desta forma, a ficção parece cair como uma luva entre os séculos XIX e início do século XX, em que a estetização do real, por meio da ficção se tornou, para algumas mulheres, estratégia de subversão do dizer. Depois disso, a sincronicidade entre autora e leitora permitiu outros artifícios que borram a fronteira do real e do ficcional, dando à luz novos lugares de enunciação. O desdobramento da escrita de si sob a égide feminista fricciona o real/ficcional em fronteiras borradas, e o uso de determinadas linguagens ou artifícios não diminui o mote disparador, mas revela as diversas possibilidades do dizer.

Lejeune entende o borramento entre a autoficção e a autobiografia como uma espécie de mutação, mas coloca a fidelidade das suas narrativas se configurando no "campo do conhecimento histórico (desejo de saber e compreender) e no campo da ação (promessa de oferecer essa verdade aos outros), tanto quanto no campo da criação artística" (LEJEUNE, 2014, p. 121), mesmo entendendo que mentira e verdade são alicerçantes nas relações sociais e não há possibilidade de alçar a verdade. Há, neste ínterim, atos que constituem inferências reais; nesse sentido, discorre:

O fato de a identidade individual, na escrita como na vida, passar pela narrativa não significa de modo algum que ela seja uma ficção. Ao me colocar por escrito, apenas prolongo aquele trabalho de criação de 'identidade narrativa', como diz Paul Ricour, em que consiste qualquer vida. É claro que, ao tentar me ver melhor, continuo me criando, passo a limpo os rascunhos da minha identidade, e esse movimento vai provisoriamente estilizá-lo ou simplificá-los. Mas não brinco de me inventar. Ao seguir as vias da narrativa, ao contrário, sou fiel a minha verdade: todos os homens que andam na rua são homens-narrativas, é por isso que conseguem parar em pé. Se a identidade é um imaginário, a autobiografia que corresponde a esse imaginário está do lado da verdade. Nenhuma relação com o jogo deliberado da ficção (LEJEUNE, 2014, p. 121).

Enquanto a autobiografia se refere a uma identidade individual, a autoficção busca uma identidade pluralizada (ROBIN, 1997, p. 16 apud FIGUEIREDO, 2013, p. 66) e os artifícios somam criações que podem pulverizar a crítica social ou amenizar dados acoplados à narrativa pessoal. 
Se estes terrenos parecem, por um lado, conflitar-se e, por outro, aproximar-se, e as forças de atração e retração ou a configuração do purismo autobiográfico, quase ingênuo, parecem também confundir os mais atentos, vamos em busca de outras forças que submetem este território em tensão. No entanto, antes de entrar no campo da arte, direcionamos para a performatividade, que tem sido material de discussão em diversos seguimentos e, por meio do uso do autobiográfico, tem diversos desdobramentos.

2.8 Performatividade de gênero e performance arte: territórios fixados?

Depois da tradução e edição do livro Problemas de gênero: feminismo e subversão da identidade, da filósofa estadunidense - que atua nas correntes feministas e queer - Judith Butler, no Brasil em 2003 (1989 nos EUA), o que mais ouvimos é o conceito de performatividade de gênero. A ligação entre o conceito-chave proposto pela filósofa fez emergir diversas manifestações artísticas ligadas a este tema. No campo das artes cênicas, por exemplo, as relações entre os dois conceitos parecem causar estranhamento e discussões do que seria uma performatividade de gênero e performance arte. De fato, existem proximidades entres eles e também distanciamentos. O fato é que nem Butler esperava tamanho interesse e uso deste conceito em relação as práticas artísticas. Diversos nomes da cena artística fazem uso da performatividade de gênero como elemento de desconstrução. E é justamente aí que as ações performativas multiplicam-se e o próprio conceito demonstra fragilidade, como bem expos a autora em entrevista ${ }^{23}$. Para dar conta dessa defasagem propõe em: Cuerpos que importan: sobre los limites materiales y discursivos del "sexo" (2002) uma reformulação dos termos.

Para formular o termo performatividade de gênero a filósofa recorre aos atos de fala $^{24}$, na prática discursiva de repetição compulsória desde a linguística (fala) até a performance de gênero, desta forma, descortina a artificialidade da representação. O gênero, para Butler, é uma construção cultural circunstancial e repetitiva. Em entrevista ${ }^{25}$, distingue duas dimensões que envolvem a performatividade de gênero: A) a primeira dimensão é a situação indesejada ou aceita da valência de gênero (desta maneira, podemos atuar nas decisões do tempo); e a segunda dimensão performativa atua na afirmação de como fomos formados sendo contra ou

\footnotetext{
${ }^{23}$ Disponível em: http://www.scielo.br/pdf/ref/v10n1/11634.pdf Acesso em: 31/07/2018, às 22h36.

${ }^{24}$ AUSTIN, John Langshaw. Quando dizer é fazer: palavras e ações. Porto Alegre: Artmed, 1990.

${ }^{25}$ Disponível em: http://carladeabreu.com/729-2/ Acesso em: 03/06/2018, às 22h36.
} 
a favor dos termos. Assim, o gênero passa a ser uma ilusão mantida pelos meios regulatórios da sexualidade e seu principal espelhamento é a heterossexualidade. Assim compreendido, o gênero é uma construção ficcional regulatória que se mantém pela performatividade de gênero, pois a performance, neste sentido, não está para algo genuíno nem real, mas para a artificialidade e para a representação mediante os meios regulatórios e citacionais. Também não corrobora com a representação da mascarada, proposta por Goffman (2014), sobre a representação no cotidiano, mas interessa na desconstrução do original. Assim, a repetição seria sempre a reprodução da reprodução e o original não existiria, ou seja, jamais existiu. Para os que não conseguem uma boa performance de seus gêneros existe consequências punitivas. A manutenção da performatividade de gênero se dá por meio de atos e por via de acordos coletivos das ficções culturais punitivas e regulatórias sob coação.

A partir do rompimento com o comportamento normativo proposto por Émile Durkheim, muitos antropólogos se debruçaram sobre estudos de indivíduos e seus respectivos dramas. Turner, Goffman e muitos outros viram, no drama social, acontecimentos com início, meio e fim, e passaram a ver esses acontecimentos não de forma espontânea, mas carregada de interesse. Na performatividade de gênero, o atuante direto é o sistema regulador citacional $^{26}$ determinante (pode haver variantes que operam também em classe e raça), enquanto que na performance arte os disparadores e atuantes podem ser múltiplos e também operar sobre o gênero.

Para Féral (2015), o teatro se distancia da performance arte, uma vez que ela esteve associada, em seu nascimento, às artes visuais, ao dadaísmo, ao surrealismo, passando pelo happening - cunhado por Kaprow (1950) -, pela body art, e isso definiria sua origem como pictorial, escultural, literária, arquitetural, além de ser afetada pelas manifestações do Fluxus. A evolução da prática da performance foi associada à inscrição problemática que envolvia a modernidade em decadência e a fragilidade na sustentação de sua ideologia esgotada pela concatenação dos modos de pensamento construídos pela noção de progresso, norma e ahistoricidade. A relação próxima entre performance arte e o moderno validou suas diferentes modalidades na recusa com o passado, efetivando sua oposição à norma tradicional estética. Desta forma, rebatia determinadas concepções artísticas e sua relação com o social. Neste pensamento, a refutação da representação - rechaçando profundamente a relação com a personagem, o papel, ensaios, catarse, valor de mercado (referente à comercialização das

\footnotetext{
${ }^{26}$ Para Butler (2001), a citacionalidade é entendida na performatividade não como ato singular ou deliberado, mas como ação reiterativa e citacional, em que o discurso nomeie os efeitos por ele produzido. BUTLER, Judith. Corpos que pesam: sobre os limites discursivos do sexo. In: LOURO, Guacira Lopes (Org.). O corpo educado: pedagogias da sexualidade. $2^{a}$ ed. Belo Horizonte: Autêntica, 2001. p. 110-125.
} 
ações em museus e galerias) e a relação entre arte e vida - se distancia ainda mais do teatro. A performance arte tem como característica primeira a recusa do signo como artefato manipulado para um determinado objetivo. "O performer não constrói signos, ele faz" (FÉRAL, 2015, p. 141) ${ }^{27}$.

Toda a força da performance está nessa convicção que ela consegue insuflar no espectador. Não! Ela não representa. Nós estamos na imediatidade da ação! Nós estamos aqui no domínio do sério. Nada é fictício. Os objetos, as ações, os seres, o tempo mesmo são reais (FÉRAL, 2015, p. 141).

A performance arte, em seu início (ano de 1970), tem a preocupação de responder aos movimentos de subversão, e o desaparecimento dessa ideologia (radicalidade) enfraqueceu a justificativa que alimentava sua prática. Féral conduz seu pensamento no deslocamento da performance arte, desde sua ligação primeira em resposta aos movimentos radicais de 1970 até hoje, em que os parâmetros e teorias que a sustentavam não são os mesmos. Daí talvez venha a junção que muitos artistas fazem da performatividade de gênero e da performance arte. Se, para Butler, a performatividade de gênero está mais para a mimese associada ao pastiche, a performance arte, como em seu início, tenta responder a esse campo minado que engloba as questões de gênero. Na busca pela fundamentação teórica e impulsionada pelos movimentos que buscam políticas públicas identitárias, a nova guinada da performance arte talvez veja, nessas manifestações, a volta de sua sustentação teórica como escopo inicial, mantendo a refutação do sistema arbitrário, na tentativa de dar voz a grupos não hegemônicos do cone Sul. E, para não dar fim à discussão, provocamos:

(...) se a performance foi, antes de tudo, uma função - função de despertar, de provocar, de tomada de posição contra a tradição, de instituir relações diferentes entre obra e o seu público - ela não tinha gênero ou forma específica, ainda que uma multidão de práticas tenham sido catalogadas sob tal denominação.

Essa diversidade das práticas e de formas às quais as performances recorrem não pode, todavia, esconder o fato de que essas últimas tinham, todas elas, uma só e mesma função: a de contestar a ordem artística e estética que prevalecia então (FÉRAL, 2015, p. 175-176).

\footnotetext{
${ }^{27}$ Exemplificaremos, no próximo capítulo, algumas performances que dialogam com tal construção, como a obra de Regina José Galindo, Himenoplastia (2004), que reforça o pensamento de Féral na prática da ação.
} 
2.9 Transições autobiográficas: da escrita às práticas artísticas

A estratégia das mulheres em inserir suas autobiografias no campo escritural fez valer outros modos de fazer para acentuar suas inserções. A concepção se dá por intermédio de diversas artistas que, em seus modos de fazer, aglutinaram texto e imagem, para reforçar suas narrativas pessoais, concebendo um desdobramento do gênero autobiográfico, "a autobiografia visual" (GUAUSCH, 2009, p. 19), por meio do uso da tríade entre vida, autora e trabalho. A composição deu origem ao autorretrato, cumprindo a conexão entre duas vontades: fazer-se ler e ver. Sua junção cumpre "la misma eficácia productora de subjectividad", como completa Guausch, ao tratar do que José Luis Brea (BREA apud GUAUSCH, 2009, p. 19) organiza como outro disparador, além da escrita na subversão das mulheres. Não obstante, o processo de inserção das mulheres na pintura foi moroso, mesmo em países como a França. No autorretrato, a relação das mulheres proporciona espaço de negociação pictórica. A fricção entre autobiografia e autoficção pode fazê-las atuar em conjunção ou a autobiografia pode fazer uso de outras linguagens e elementos (adereços, palavras escritas no corpo, dentre outras possibilidades), para potencializar a escrita de si, não adentrando o campo da manipulação, mas forjando, depois de detectar problemas de outra ordem.

Para Guausch (2009), tanto o autorretrato como a escrita de si apresentam potencialidade e maior efeito na espectadora/leitora e, consequentemente, um efeito de verdade além da ficção ${ }^{28}$, pois ao concordar com Brea, a autora, sustenta que a autobiografia é autoprodutiva.

La autobiografia [...]es autoproductiva: es el paradigma mismo del texto performativo, como tal produtor de 'realidad' - toda vez que su produto es su próprio presunto produtor -. Em realidade todo texto, como operador de potencial performativo, es em prime lugar el produtor del sujeto que lo enuncia: de él el texto es la más importante indústria, la principal y más efectiva fabrica (GUAUSCH, 2009, p. 19).

No Brasil, destacamos Georgina de Albuquerque (São Paulo, 1885-1962), pioneira em obras de grandes dimensões, que usou, de maneira subversiva, seu olhar para um momento histórico do país, na comemoração do centenário da Independência. E, ao invés de narrar cenas de batalha por meio de imagens, como de costume, retratou uma cena em gabinete

28 Tradução nossa. 
oficial, destacando de forma heroica uma mulher. Ela também se retratou em pintura para eternizar sua imagem no tempo e na memória dos que insistem em inferiorizar as mulheres.

As miudezas perversas nestes pequenos deslocamentos da inserção da mulher em um local de visibilidade vêm sendo traçadas vagarosamente e ganhando outras possibilidades visuais. A inversão da escrita no papel para a fotografia e, logo depois, a imagem em movimento, o vídeo, fez valer mais experimentos. O processo de veiculação quase instantânea da fotografia e do vídeo, e o imediatismo preciso de fatos ocorridos na reconstrução factual dos aspectos vividos, também contribuíram na rapidez das mensagens e pensamento acerca do feminismo.

Neste território expandido de experimentação e olhar crítico, a arte conceitual e, logo depois, em 1970, o nascimento da performance arte, composta pelas diversas linguagens, dão margem para a aproximação entre arte e vida, em um contexto crítico e subversivo. Não há como falar de feminismo, gênero e teoria queer sem reconhecer a importância da performance arte nesses contextos.

2.10 O que a obra tem a dizer?

Nos estudos da contemporaneidade, a arte tem esmiuçado a relação entre arte e vida nas diversas variáveis. Tendo em vista que as mulheres avançam em espaços de circulação pela mesma premissa de que as diferenças tornam componentes combinatórios nas relações com o real, o uso do autobiográfico se torna recorrente na cena artística. As políticas da mulher estreitam ainda mais a relação arte e vida, já que o corpo ganha conotações não simbólicas e intransponíveis nos planos da ficção. As visitas em torno do material autobiográfico crescem com a conectividade de resposta aos processos emancipatórios que fazem uso dessas imbricações por meio da radicalidade das manifestações artísticas. Neste aspecto, o gênero puro, autobiográfico, se encontra na miríade producente deste pulsar, uma vez que passa a ser um agente negociador em que as variações - escrita de sí, autoescrituras, autonarrativas, autorrepresentação, autorreferencialidade, autoexpressão, depoimento pessoal etc. - atuam na linha factual entre realidade e autoficção. A composição em que o objeto do discurso age na valência da obra e não restringe a um modelo único e muito menos a um gênero puro. Sobre isso, Leite comenta: 
(...) necessário inventar a forma que convém a cada experiência. Essa afirmação é chave dentro da reflexão que estamos propondo. Em primeiro lugar, porque ela afirma que não há uma maneira natural, objetiva de se narrar a vida, em segundo lugar, porque traz para o plano da invenção a produção dos enunciados sobre a nossa experiência.

Se por um lado, o autobiográfico aclamado enquanto gênero puro, distinto da ficção, incomoda pelo que parece ser uma pretensão ingênua ou mesmo uma limitação expressiva baseada no contingencial e no anedótico, por outro lado, a arte contemporânea mostra a imensa quantidade de artistas que recorrem a sua experiência pessoal como base e material para a criação (...) (LEITE, 2017, p. 17-18).

Desta forma, buscamos olhar para ações performáticas artísticas na resistência aos constructos do biopoder ${ }^{29}$, exemplares no debate do campo da autobiografia das mulheres que, de maneira radical, usaram suas vidas para tensionar a visão naturalizada nos enfrentamentos da violência doméstica, objetificação de seus corpos, direito ao aborto, equidade no trabalho, divisão das tarefas domésticas, determinismo biológico, estética genital, como veremos no próximo capítulo.

${ }^{29}$ Cunhado por Michel Foucault como diversas técnicas desenvolvidas pelos estados modernos para controlar e subjugar os corpos. 


\section{DERIVAÇÕES ESTÉTICAS DO EU}

3.1 Estratégias do dizer

Há, de um lado, a arte não formalizada, fugaz, 'bruta', e, de outro, uma arte que foi, por assim dizer, registrada em um meio comumente reconhecido como artístico.

(Clement Greenberg)

$* * *$

Sem dúvida, o esgotamento das definições restritivas de arte e artista, identidade e comunidade também foi provocado pela pressão dos movimentos sociais (direitos civis, feminismos diversos, políticas queer, multiculturalismo), bem como dos desenvolvimentos teóricos (a convergência do feminismo, da psicanálise e da teoria do cinema;

o resgate de Antonio Gramsci e o desdobramento dos estudos culturais na Grã-Bretanha; as aplicações de Louis Althusser, Lacan e

Foucault, especialmente na revista britânica Screen; o desdobramento do discurso pós-colonial com Edward Said, Gayatri Spivack, Homi Bhabba, entre outros, e assim por diante). Portanto, a arte passou para o campo ampliado da cultura, que supostamente é domínio da antropologia.

(Hal Foster)

Destacamos, neste fragmento, indícios encontrados na cena artística que, por meio das visitações autobiográficas - que, neste contexto, entendemos como zona fronteiriça e borrada com o autoficcional - apresentam-se como dispositivos vestigiais acerca da categoria mulher. Parte-se de ações artísticas que tratam de temas motores de processos que podemos analisar como indícios emancipatórios concernentes ao gênero. 
Segundo $\operatorname{Rago}^{30}$ (2011), alguns trabalhos não tiveram a preocupação de atrelar-se ao campo feminista ${ }^{31}$. Assim, preocupamo-nos em trazer como discussão obras que submetem os diversos segmentos que alimentam a autobiografia, atrelada ao que podemos entender como diálogo frente aos estudos feministas. Antes do século $\mathrm{XIX}^{32}$, diversas manifestações artísticas contribuíram para o pensamento e expressão das mulheres. No entanto, direcionamo-nos para a performance arte ou performance ${ }^{33}$, como manifestação contemporânea que escapa das categorias institucionais e não apresenta possibilidade hermenêutica, e que mostra-se como um grande caldeirão para pôr em questão os problemas relacionados ao gênero.

Taylor (2013), em sua célebre contribuição acerca da performance e memória cultural nas Américas, recorre a diversos níveis atribuídos a performance, dentre eles, a transferência de conhecimento e memória no âmbito da identidade social, definida por Richard Schechner ${ }^{34}$ como comportamento reiterado. No primeiro nível, o que define performance é objeto/processo, ou seja, acontecimentos - dança, teatro, funerais, comícios políticos, manifestações populares, protestos - que envolvam elementos teatralizados e que reforçam a proposta apresentada. Contudo, a performance tem um sentido ontológico localizado; assim, cada sociedade define se tal manifestação é ou não performance. O segundo nível apresenta um olhar metodológico, ao analisar manifestações públicas como performances, adentrando

\footnotetext{
${ }^{30}$ RAGO, Margareth. Espaços autobiográficos nos feminismos. In: XXVI Simpósio Nacional da ANPUH Associação Nacional de História. Anais, São Paulo, julho 2011. ISBN: 978-85-98711-08-9. Edição: 1. Ano da Edição:2011. Local de Edição: São Paulo. Tipo de Suporte: Internet. Editora: ANPUH-SP.

${ }^{31}$ Utilizado por Sonia E. Alvarez para designar uma re-visão epistemológica, para repensar os feminismos no Brasil e na América Latina, em que ela procura elaborar uma linguagem conceitual e formas de análise para entender as mudanças dos feminismos contemporâneos; desta forma, coloca os feminismos em um campo discursivo de ação. ALVAREZ, Sonia E. Para além da sociedade civil: reflexões sobre o campo feminista. Cad. Pagu [online]. 2014, n.43, pp.13-56. ISSN 1809-4449. Disponível em: http://dx.doi.org/10.1590/01048333201400430013 Acesso em: 10/03/2018, às 15 h50.

32 Ana Paula Cavalcanti Simioni apresenta um grande panorama a partir do século XIX, através de análise historiográfica/documental das mulheres artistas silenciadas e anônimas no Brasil. Sua contribuição diagnostica artistas que antecederam Anita Malfatti e Tarsila do Amaral, na assertiva observação de estratégias em que a figura do autoritarismo tradicionalista deixou às sombras produções de artistas que antecederam cânones do modernismo. Aponta para a profissionalização artística ao amadorismo, ao se referir às mulheres artistas. Analisa traços e contornos estéticos como uma prática destinada às mulheres em que a sutilidade e reprodução de adornos, comumente encontrados no lar, estigmatizaram formas de representação pictural nas produções delas. Cf. SIMIONI, Ana Paula Cavalcanti. Profissão Artista: Pintoras e Escultoras Acadêmicas Brasileiras. São Paulo: Fapesp, 2008.

${ }^{33}$ Diana Taylor problematiza a tradução da palavra "performance" na América Latina, em que o termo não chega na sua tradução equivalente ao inglês. No português do Brasil e espanhol dos países da América Latina, atribuise à performance o sentido de performance arte, e sua tradução, por vezes ambígua no espanhol (la performance ou el performance), propõe aos estudos da língua inglesa pensar na performance de sexo e gênero (el/la). Exemplifica: el performance é um termo destinado a acontecimentos oriundos da política ou dos negócios e la performance associado geralmente ao que se refere às artes.

${ }^{34}$ SCHECHNER, Richard. O que é performance? In. Performance studies: an introduccion, Second edition. New York \& London: Routledge, 2006. p. 28-51.
} 
resistências, cidadania, etnicidade, identidade sexual, gênero e obediência cívica. (TAYLOR, 2013, p. 27). A autora compreende performance na tensão entre ontologia e construção. Para Schechner a performance está calcada na ontologia, ou seja, na experiência humana; Taylor reforça a ambiguidade entre ontológico e construído, na incidência de que a performance é tanto real como construída. Neste sentido, "a performance e a estética da vida cotidiana variam de comunidade para comunidade, refletindo a especificidade cultural e histórica existente tanto na encenação quanto na recepção" (TAYLOR, 2013, p. 27). Schechner se aproxima de Marvin Carlson, atribuindo performance como cultura e, desta maneira, toda experiência humana seria performance. Assim, entendemos que ambos, Schechner e Carlson, esbarram na fenomenologia para definir performance. O segundo nível apresentado por Taylor é o que melhor abarca as questões concernentes às mulheres. No exercício sobre gênero (masculino e feminino), dão margem para colocar, a partir da performance, histórias pessoais borradas pela moldura estética em um limiar não claro entre a autobiografia e a autoficção.

Leite (2017) afirma que a literatura, as artes visuais e a performance exibem mais declaradamente obras autobiográficas, não apenas no sentido de harmonia e cura, mas no enfrentamento de pontos nevrálgicos da experiência humana, transformando imagens em existência política e subjetiva. Assim, pensamos em determinadas obras como dissolução da individualidade, como ferramental de experiências que comungam um ato de existência política.

3.2 A utilização do corpo: Pose, narcisismo ou posicionamento político?

Manipular e recriar momentos pessoais trouxe questões referentes aos papeis sociais, sobretudo para as mulheres que viram na performance autobiográfica outras possibilidades que não as apresentadas pelos performers do sexo masculino (GOLDBERG, 2006, p. 164).

Barros (2016) aponta que a exploração do $e u$ foi estratégica para as artistas feministas que viam na tática militante o levante de que o pessoal é político ${ }^{35}$. Alavancadas pela body art, o corpo nu e a utilização da genital feminina, buscaram explorar assuntos da casa para a

\footnotetext{
35 Texto de Carol Hanish, publicado em 1969, durante a segunda onda feminista (1960-1980), implicando cada um nos processos políticos, e que buscava romper as barreiras do privado e do público. Disponível em: http://carolhanisch.org/CHwritings/PIP.html Acesso em: 03/08/2018, às 13h27.
} 
rua, em um âmbito de que o privado resguardava camadas de exploração e violência doméstica. Na dúvida se as ações apresentadas eram reais ou ficcionais, as narrativas denunciavam atos de violência doméstica geralmente atribuídos a alguém próximo a elas. A relação do pessoal e político ressoou de diversas formas nas artes visuais e abriu para as mulheres um campo vasto de experimentação. Nesse contexto, o depoimento pessoal, o corpo e a rotina doméstica se tornam disparadores e negociadores das regras impostas.

Leite (2017) reconhece que somente com a performance arte os depoimentos pessoais ganham e geram autonomia, na medida em que o depoimento é peça chave para atingir a expressão do individual para o coletivo, ou seja, ao expor sua singularidade "a história de cada um passa a ser a história de todos". (LEITE, 2017, p. 38). A autora traz a performance arte, por meio dos artistas Marina Abramović, Joseph Beuys e Spalding Gray, como paradigma do depoimento radicalizado, expresso pelo corpo e pelo uso de elementos biográficos que, para ela, apresentam-se pela memória.

Untitled Rape Scene (1973), obra que a artista cubana Ana Mendieta realizou em seu apartamento, reportava uma violência de estupro ocorrida na Universidade de Iowa (EUA). A artista, que chegou aos Estados Unidos depois de ser enviada pelos seus pais contrários ao regime castrista em 1961, teve ao longo de seus trabalhos artísticos um trânsito entre suas memórias cubanas e estadunidenses. Ela e sua irmã - que também havia sido enviada pelos pais por meio do programa Peter Pan, da Igreja Católica, aos EUA, numa tentativa de resguardar as crianças do regime comunista de Fidel Castro (1926-2016) - viveram parte de suas vidas em Iowa, com uma família adotiva.

Sensibilizada pela violência ocorrida na Universidade de Iowa, Mendieta convida amigos para uma visita em seu apartamento e os recebe com a porta entreaberta. Ao adentrarem, os amigos da artista se deparam com seu corpo debruçado sobre a mesa, despida da cintura para baixo; o corpo ensanguentado com respingos pelo chão e objetos quebrados no espaço. O lar, simbolicamente tido como local confortável e seguro, se transforma em um espaço para a ação. A escolha de transposição do privado para o público, como ambiente performativo, submete elementos importantes que evidenciam o lar como lugar vulnerável e frágil ${ }^{36}$. Realizar a performance no próprio lar, e não em um museu ou galeria, potencializa as camadas verossímeis da ação e denuncia violências ${ }^{37}$ cometidas por pessoas próximas. A

\footnotetext{
${ }^{36}$ Em pesquisa realizada pelo Núcleo de Estudos da Violência da USP e o Fórum Brasileiro de Segurança Pública, notificou-se que, do ano de 2016 para o ano de 2017, houve um aumento de 6,5\% de feminicídio no Brasil.

37 Em 2013, na cidade de São Paulo, foram criadas, pelo ex-prefeito Fernando Haddad, do Partido dos Trabalhadores (PT), as Secretárias de Igualdade Racial e Política para as Mulheres. Na atual transição da gestão
} 
fricção com as camadas do real faz alusão a fatos cotidianos, mas que apresentam molduras estéticas na arte para reportar temas dilacerantes e concernente às mulheres: estupro, aborto, empregabilidade etc. Sem a moldura tensional da ficção, o que haveria seria um julgamento, em que pesaria pensar se ela não teria feito nada que contribuísse para tal atitude. A culpabilização, por vezes dada a mulher, em fatos e acontecimentos relacionados ao estupro, em meados de 1970, era direcionada (e ainda é) à vítima. Neste sentido, Mendieta alude não apenas a uma ação que fatalmente aconteceu com uma mulher, aluna da Universidade que estudava, mas mostra que, para colocar em questão determinados fatos, é necessário o jogo de esconde-revela. Ao convidar seus amigos, por meio da ação performática, submete-os à questão condicional de violência que encontram seus corpos.

No mesmo ano, a estética feminista vinha numa tentativa de desviar o corpo da mulher para o não essencialismo e universalismo. Caminhava para um corpo autônomo, descontruído de estereótipos. Necessário ressaltar que, em 1971, Linda Nochlin (1988) publicou um ensaio que questionava o reconhecimento de mulheres artistas. Sua provocação Porque nunca existiram mulheres artistas ${ }^{38}$ - desestabilizava a lógica dominante das curadorias e diretores de museus que colocavam as artistas mulheres em local de subserviência. Mendieta, ao negar o museu como local para sua performance, não somente abre espaço para outros locais de enunciação, mas para (re)significar o espaço dado à performance, a partir de temas imbricados nas vivências pessoais. O local das ações performáticas passa a ser um dispositivo documental da memória. Estar ali é ativar as reminiscências deixadas pelo fio condutor do tempo.

Em contrapartida, em 1978, passa a integrar a AIR Gallery (1972), um espaço destinado à obra de mulheres artistas sub-representadas, que viam a necessidade de criar um espaço de maior difusão de seus trabalhos. Na convivência com outras artistas, Mendieta diagnostica as diferentes pautas das mulheres e nos dá pistas de um feminismo pautado nas diferenças de classe e raça. Desta maneira, a análise parcial do movimento feminista, que pensava na categoria das mulheres brancas, impulsionou Gloria Jean Watkins a utilizar o

do ex-prefeito João Dória, do Partido da Social Democracia Brasileira (PSDB), para o atual prefeito Bruno Covas (PSDB), as duas Secretarias foram extintas por meio da Lei 16.974, de 23 de agosto de 2018.

${ }^{38}$ Em 2017, o MASP (Museu de Arte de São Paulo Assis Chateaubriand) deu vazão às diversas exposições e discussões atreladas ao feminismo. Guerrilha Girls, História das mulheres, Histórias feministas e depois com o presente cenário de diversas exposições com obras de arte censuradas no Brasil, bateu recorde com a exposição História da Sexualidade. Disponível em: https://www1.folha.uol.com.br/ilustrada/2018/02/masp-bate-recordescom-historias-da-sexualidade.shtml

Acesso em: 18/05/2018, às 19h08. 
nome de sua bisavó bell hootz ${ }^{39}$. Assim como ela, outras mulheres usaram nomes de suas ancestrais para ovacioná-las e criticar que foram manuseadas como produtos pelas mulheres brancas que as antecederam. Logo depois, bell hooks lança o livro Ain't I a Woman: black women and feminism (1981), pontuando que mulheres brancas e norte-americanas do Movimento de Liberação das Mulheres excluíam a representatividade de determinadas categorias - classe e raça - como fatores determinantes de opressão (STUBS, TEIXEIRAFILHO, GALINDO e MILIOLI, 2015) $)^{40}$.
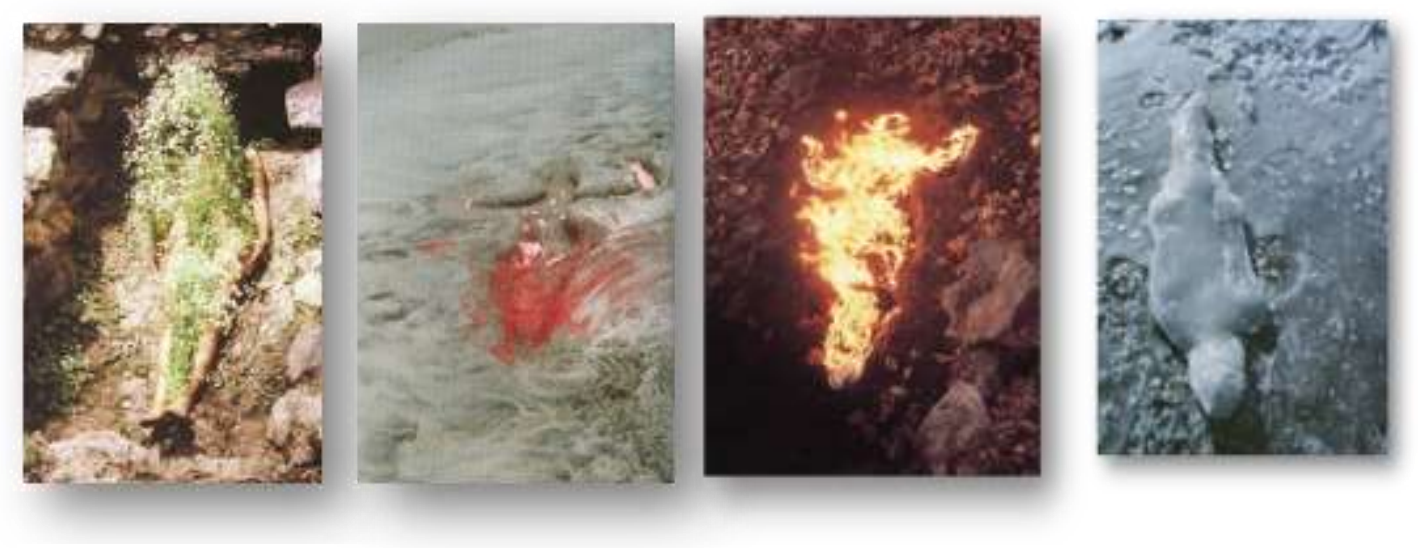

Figura 1. Ana Mendieta (Silueta), México:1973/1976/1977. Foto: Yagul.

Notadamente, a morte de Mendieta em 1985 teve várias interpretações, mas foi dada como morte por vias de suicídio. Seu companheiro na época, o artista minimalista Carl Andre, que estava com ela minutos antes, declarou que Mendieta se jogou da janela do quarto do casal, que viviam no $34^{\circ}$ andar em Manhattan. Vizinhos relataram ter ouvido uma discussão antes dela cair da janela de seu apartamento em Nova Iorque. Carl Andre foi suspeito da morte da artista, mas foi absolvido em audiência judicial. Foi solto após Frank Stella, artista branco norte-americano, ter desembolsado uma quantia alta para liberar o amigo. Em depoimento, Andre declarou: "Sou um artista muito famoso e ela não era. Talvez isso tenha acabado com ela". ${ }^{41}$

\footnotetext{
${ }^{39}$ Glória Jean Watkins optou por usar o pseudônimo de sua bisavó materna Bell Blair Hooks em minúsculo (bell hooks), reforçando atenção na mensagem sobre a ausência dos debates em torno da mulher negra, ao invés de centralizar em si mesma.

${ }^{40}$ Disponível em: STUBS, Roberta; TEIXEIRA FILHO, Fernando Silva; GALINDO, Dolores; MILIOLI, Danielli. Corpos, subjetivações estéticas e arte e feminismos: passagens na pesquisa em Psicologia. Fractal, Rev. Psicol. [online]. 2015, vol. 27, n. 3, pp. 211-218 Dispoonível em: http://www.scielo.br/scielo.php?pid=S1984-02922015000300211\&script=sci_abstract\&tlng=pt Acesso em: 02/08/2018, às 18 h06.

${ }^{41}$ Disponível em: https://www.select.art.br/machismo-no-mundo-artistico/ Acesso em: 03/01/2019, às 17h59.
} 
Sua morte causou diversas manifestações que incisivamente condenavam Carl Andre pela morte da artista. Alguns relatam, na época, que as divergências entre o casal vinham de disputas profissionais. Com a morte de Mendieta e a suspeita de Andre, os artistas da época, em Nova Iorque, tomaram partido em defesa do artista, afirmando sua inocência. A absolvição de Andre teve como justificativa a instabilidade mental de Mendieta, apoiada pela análise da série de obras Silueta (1973-1980). Nesta série, o uso de materiais como areia, barro, fogo e sangue reforçaram, segundo a defensoria, ideias suicidas e instabilidade mental.

Mendieta foi uma mulher consciente de seu tempo e suas obras dialogavam diretamente com acontecimentos da época. O feminismo de enfrentamento a moldes enrijecidos das estadunidenses, sobretudo na arte, dialoga com o rompimento das esferas público/privado, calcado nas diferenças das mulheres Latinas.
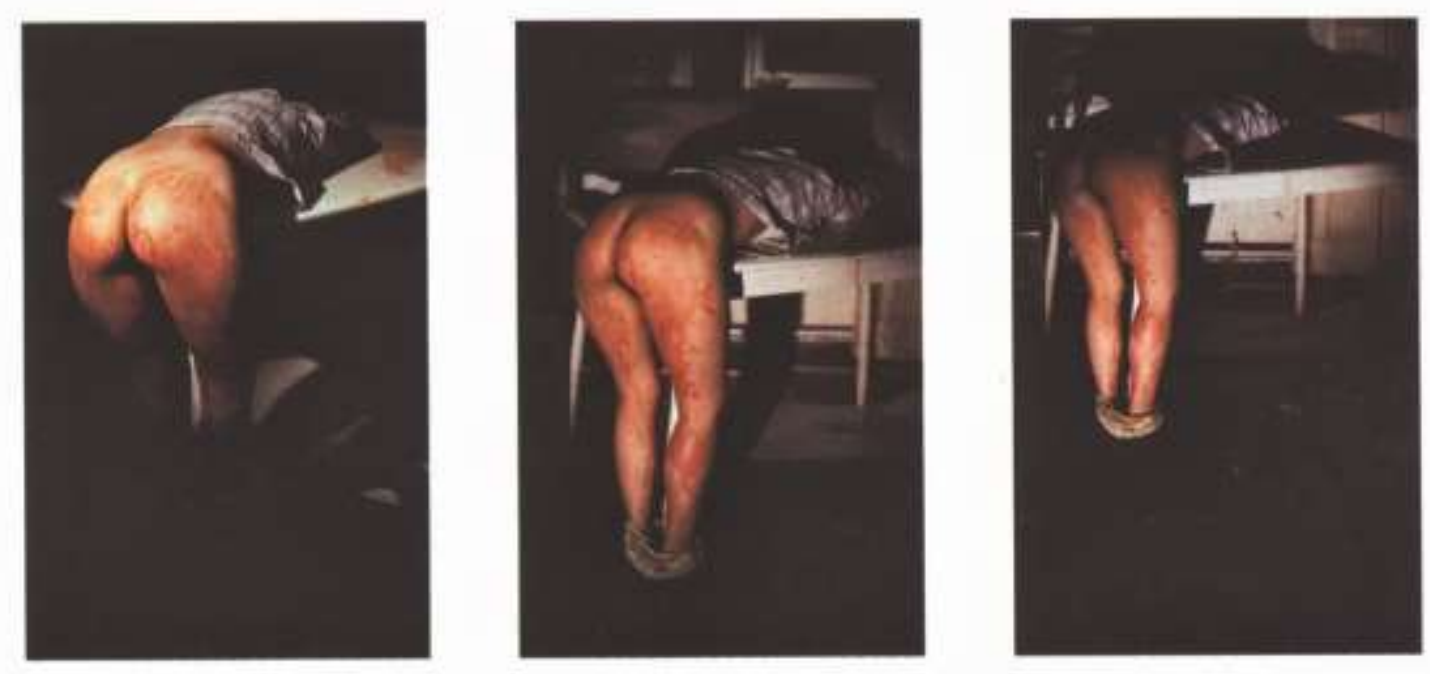

Figura 2. Ana Mendieta, Untitled (Rape Scene), Abril/1973, apartamento da artista. Foto: documentação em performance 245x170mm. Fonte: http://swanyart.com/living-art.

\subsection{Deslocamentos: da terra ao corpo}

O ato criacional trouxe elementos como barro, planta, sangue etc., como nas obras de Mendieta, que, ao serem acoplados ao corpo, possibilitaram leituras que extrapolaram o plano simbólico. O sangue e a terra usados na obra Silueta trouxeram tentativas de sair do singular e saltar para um diálogo que alçasse questões universais. Na América Latina, os conflitos territoriais, étnico-raciais e de classe são lutas banhadas a sangue e sêmen. A memória 
borrada por estes conflitos tenta reerguer-se numa perspectiva de representações políticas democráticas que vislumbre equidade ${ }^{42}$ em diversas categorias.

A autora María Lugones $^{43}$ (2014) propõe uma reflexão moderna sobre a relação categorial dicotômica apoiada pelo pensamento capitalista e colonial sobre raça, gênero e sexualidade. Em favor da ocidentalidade, hierarquias foram impostas, começando pela colonização das Américas e do Caribe, nas quais a divisão entre homem e mulher se torna marca do humano. A exclusão de povos (indígenas e africanos) acarretou em um pensamento que os designou como não humanos. Assim, "o homem europeu, burguês, colonial moderno tornou-se um sujeito/agente, apto a decidir, para a vida pública e o governo, um ser de civilização, heterossexual, cristão, um ser de mente e razão" (LUGONES, 2014, p. 936). A mulher europeia, neste contexto, destinava-se à reprodução e cultuava o bem-estar do lar. A aposta da pesquisadora é insistir nas relações da vida social que resistem à diferença colonial; e, desta forma, assumir a diferença permite manifestação fora da ordem dicotômica.

Em países da América Latina, houve, no campo das artes, escolha por outras materialidades (barro, sangue, areia etc.) que não eram utilizadas pelas artistas do Cone Norte, que neste momento investiam na relação do corpo com meios tecnológicos (vídeo e fotografia). A relação entre terra e sangue, por vezes, estava associada a conflitos silenciados. Por este ângulo, Mendieta antecipa os conflitos que alicerçam as manifestações de direitos da mulher, bem como, no Brasil, Celeida Tostes (1929 - 1995) expunha relações de gênero.

Na performance Passagem (1979), a artista brasileira Celeida Tostes faz, em seu apartamento, no Botafogo/RJ, uma ação de fusão da mulher com o barro (argila). O registro feito pelo fotógrafo Henri Stahl permite visualização da performance que ocorreu sem nenhum espectador, com exceção de duas mulheres que a ajudaram no manuseio do barro. A fotoperformance ${ }^{44}$ proporcionou um salto na carreira da artista. Anos antes da performance,

\footnotetext{
42 PIERUCCI, Antônio Flávio. Ciladas da diferença. São Paulo. Editora 34, 2013.

${ }^{43} \mathrm{O}$ artigo foi originalmente publicado pela Hypatia, v. 25, n. 4, 2010 e traduzido, com autorização da autora, em 2014, pela Revista de Estudos Feministas, da UFCS.

${ }^{44}$ A denominação de fotoperformance no limiar entre performance/ação e registro vem sendo discutida com intensidade após o crescente interesse, por parte das organizações financiadoras, em adentrarem a performance na programação dos locais de fruição. Como desdobramento deste crescimento, surge a fotoperformance, para dar conta de ações performáticas ocorridas e por tal relevância se postam em formato de exposição. Diferem em pontos iniciais do roteiro: se o disparador para a foto da ação/acontecimento se torna documental ou se a foto de uma determinada ação é roteirizada para o obturador. Segundo Neves (2012), a fotoperformance se configura como um trabalho performático autônomo e não como objetivo documental de registro fotográfico, assim a fotografia não é documento, mas um meio especifico de circulação da performance. Neste sentido, a fotografia é tida como performance mesmo quando o objeto artístico se configura na imagem fotográfica; desta forma, o corpo da artista se torna foco, pois a performer, no momento da ação, esteve a performar para a câmera. Desta maneira, a fotografia tem por finalidade a concepção da performance. Cf. NEVES, Daniele Quiroga. Performance e registro: a produção performática de Claudia Paim. XI Seminário de História da Arte. Rio
} 
em 1975, a Organização das Nações Unidas (ONU) declarou Ano Internacional da Mulher, em um contexto de diversas repressões militares - devido à ditadura no país - e em que muitas mulheres periféricas lutavam para garantir comida a seus filhos por meio do Movimento do Custo de Vida. Neste cenário, nasce o interesse, vindo de duas militantes Terezinha Zerbini e Joana Lopes - de criar um meio de comunicação que atendesse ao levante de resistência militar no país. O jornal Brasil Mulher ${ }^{45}$ é criado, como possibilidade de dar voz a essas mulheres, e, em sua primeira edição, contou com a foto de uma mulher negra e periférica para aludir à discussão racial. Esta imprensa clandestina era composta por mulheres vindas da luta armada, como Maria Amélia de Almeida Teles (Amelinha) ${ }^{46}$. No mesmo ano, outros episódios marcaram a luta das mulheres no Brasil: a criação do Movimento Feminino pela Anistia e o Seminário sobre o Papel e o Comportamento da Mulher na Sociedade Brasileira, considerado um marco para o feminismo no Brasil. O evento visava discutir temas de saúde física/mental, racismo, relações trabalhistas, homossexualidade feminina e posicionamento a favor da democracia. No dia 8 de março de 1975 (conhecido internacionalmente como dia da mulher) a Reunião de Feministas na Associação Brasileira de Imprensa $(\mathrm{ABI})$ no Rio de Janeiro, apresentou pautas referentes às mulheres negras no movimento feminista, gerando um documento sobre as crueldades da escravidão e objetificação do corpo da mulher negra. No fim do ano de 1977, elas abordaram a Lei $n^{\circ}$ 6.515 sobre o divórcio como dissolução dos casamentos. Em 1979, a equipe feminina de judô, por intermédio de pseudônimos masculinos, inscreveu-se para disputar o campeonato SulAmericano, pois o Decreto ${ }^{\circ} 3.199$ do ano de 1937, regulamentado no ano de 1965, impedia mulheres de praticar esportes que colocassem em voga a condição de seus corpos. No entanto, somente com a pontuação dessa equipe o Brasil conseguiu conquistar o título, levando o Governo Militar a revogar tal decreto ${ }^{47}$.

Vivendo em um período de resistência e criação dos movimentos, a obra de Celeida Tostes incide sobre motivações essencialistas e maternais da condição da mulher. Impossível dissociar os impulsos criadores atrelados à condição de útero e ao nascimento, quando o

\footnotetext{
Grande do Sul, $\quad \mathrm{N}^{\circ} 2, \quad 2012 / \quad$ ISSN: $2237-1923 . \quad$ Disponível $\quad$ em: https://periodicos.ufpel.edu.br/ojs2/index.php/Arte/article/view/1703 Acesso em: 15/03/2018, às 02h34.

${ }^{45}$ Disponível em:

http://operamundi.uol.com.br/conteudo/geral/48445/brasil+mulher+luta+feminista+por+liberdade+e+anistia.sht ml. Acesso em: 16/03/2018, às 17h10.

${ }^{46}$ Disponível em: http://www.naomekahlo.com/single-post/Mulherio-a-imprensa-feminista-na-ditadura-militar. Acesso em: 16/03/2018, às 22h30.

${ }^{47}$ Disponível em: https://jornalggn.com.br/noticia/linha-do-tempo-feminista-no-brasil Acesso em: 16/03/2018.
} 
cenário social reivindica melhores condições para mães de família que eram (e são) gestoras de seus lares.

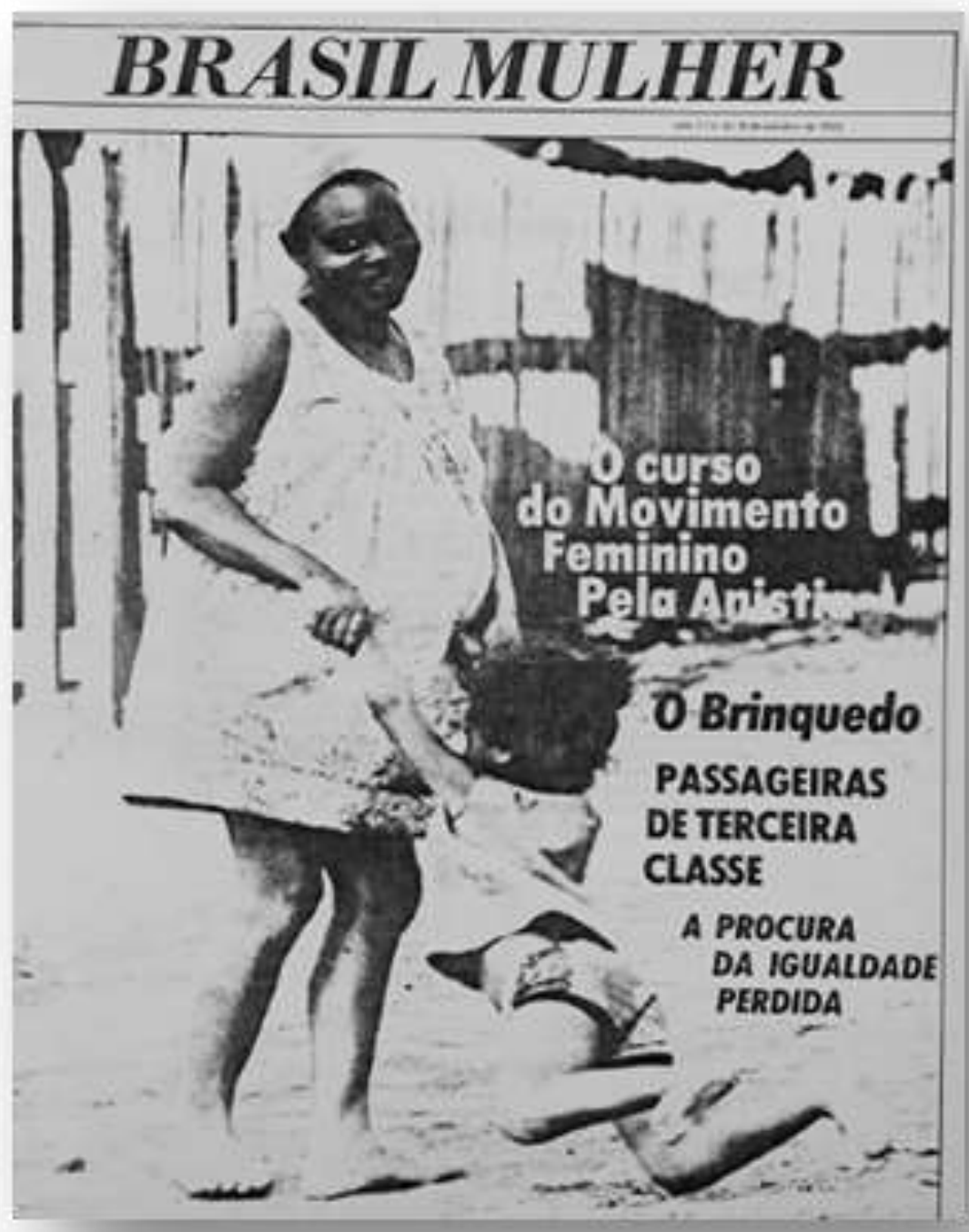

Figura 3. Capa Jornal Brasil Mulher, 1975.

Optamos por elucidar questões referentes à colonialidade em sua obra, não na forma representacional $^{48}$, já que Tostes era uma mulher branca, mas no campo da utilização e escolha de materiais referentes às territorialidades que sustentam, além de outros pilares, a questão colonial. Neste sentido, a manutenção de espaços de dominação garante estruturas

\footnotetext{
${ }^{48}$ Dos debates em torno da representatividade ligada aos enfrentamos de colonialidade, iremos tratar deste assunto através dos materiais representacionais (terra) e deixar que as vozes e copos imbuídos do seguimento étnico-racial posicionem outros enunciados, a partir das esferas do corpo/existir.
} 
que submetem as mulheres a espaços de subserviência. No ano de 1980, a artista ministra oficinas de cerâmica na Penitenciária de Belo Horizonte/MG e, entre os anos de 1980 e 1995, coordena o Projeto de Formação de Centros de Cerâmica Utilitária, nas comunidades periféricas da região do Morro do Chapéu Mangueira/RJ. O cuidado de Tostes em multiplicar seu trabalho como aprendizagem em outros espaços de circulação e para diferentes corpos remete ao cuidado dela em procurar, fora do eixo cultural, ações multiplicadoras. Dizia que não ensinava cerâmica (argila), mas cultuava uma postura de vida a partir da relação com o barro. O trabalho político exercido pela artista propunha refletir sobre a prática de estar ali como forma de valorizar suas origens. Muitas mulheres ficavam em casa cuidando de seus filhos e, junto da artista, criaram a creche para deixar as crianças, enquanto praticavam outras atividades. Deixadas na creche, no próprio ateliê da artista, as crianças podiam brincar com o barro, e o material desenvolvido por essas mães compunha a renda familiar.

Tostes, que desde a infância cultuava a vida simples no campo, tensionava a relação sociopolítica cultural a partir das ações realizadas por meio da arte.

\subsection{Espaços de (re)nascimento}

A experiência da performance Passagem (1979) alça a relação entre arte e vida de Tostes. Carioca, nascida em 1929 no Rio de Janeiro, teve a mãe falecida ainda criança. Foi criada pelas tias e avós maternas em uma fazenda no interior fluminense, local que propiciou contato com a natureza, animais e sobretudo com o barro, que a acompanhou desde os primeiros anos de vida. Depois de sua aproximação com as mulheres do Morro do Chapéu da Mangueira, os atravessamentos entre memória e experiência pessoal influenciaram a artista e seu (re)nascimento na ação com o barro. A performance não somente trazia a ideia de renascimento feminino, mas o enfrentamento de acontecimentos e vivências ocorridas. $\mathrm{O}$ corpo violado leva consigo conflitos silenciados ou pouco atribuídos ao poder público, pois traz uma parcela da população que o Estado, por vezes, quer banir. Os territórios em conflito, bem como o corpo da mulher, tornam-se dispositivos de estruturas maiores que operam nessas vertentes, ditando moldes e formas de existência. Em 1979 (e ainda hoje), no Brasil, poucas mulheres se reconheciam feministas, apenas as militantes vindas da luta armada se definiam como tal. Celeida Tostes também não se reportava ao feminismo, mas suas obras e a relação com o barro levantam um questionável pensamento artístico sobre gênero. Além da representação da genital feminina em suas obras, criada por meio do barro, a performance em 
que ela, nua, se enclausura no útero do barro para renascer delibera um rito de passagem em que, ao ser revestida de outra roupagem, produz força, da qual as mulheres - e sobretudo mulheres negras e indígenas - resistiram (resistem) a tempos difíceis. Residentes de uma terra de ninguém, essas territorialidades (Morro do Chapéu da Mangueira) representavam as violências pouco relatadas pela imprensa da época (jornal impresso). A marginalidade atribuída a esses territórios e também a territorialidade do corpo da mulher, agora (re)nascido, produzem um corpo teso, mesmo em estado de vulnerabilidade em consequência do sistema arbitrário.

Butler (2015) questiona como os sujeitos podem ser representados na legislação, na qual qualquer direção escolhida leva ao normativo que direciona a ideia do humano, digno de reconhecimento e representação. A abrangência nessa questão faz analisar o diferencial de poder que determina quais sujeitos serão reconhecidos e quais não. Neste sentido, os povos originários da América Latina, considerados não humanos, concordando com Lugones (2014), que propõe não apenas o termo colonialidade em relação a gênero e poder, mas em relação ao "processo de redução ativa das pessoas, a desumanização que as torna aptas para a classificação, o processo de sujeitificação e a investida de tornar o/a colonizado/a menos que seres humanos" (LUGONES, 2014, p. 939). Ao renascer do enclausuramento útero/barro, a artista expressa um outro corpo apto a resistir às normas e aos agenciamentos engendrados em um corpo enlameado, sem curvas definidas, sujo, contudo pulsante. Detecta o elo forte com suas memórias e história de vida. Tanto Tostes ${ }^{49}$ como as mulheres do Morro do Chapéu da Mangueira representam resistência, ou seja, a tensão da sujeição à norma.

A representação da materialidade acoplada ao corpo da artista faz do barro um elemento geográfico. Como a própria colonização das Américas, suas violências e estados de sujeição ao qual seus povos foram submetidos endereçam o processo de oprimir/resistir calcado na resistência à diferença intersubjetiva.

Concordo com os críticos que dizem ser "Passagem" o meu trabalho matriz - ele que foi uma tentativa de voltar ao útero de uma mãe que não conheci. Tem uma ligação muito forte com a minha história de vida. Surgiu após uma fase em que eu estava fazendo bolas, fazia bolas que não acabavam mais e colocava coisas dentro delas, coisas que faziam uns barulhos. Então me dei conta de uma lembrança da fazenda, de uma antiga empregada que dizia que os bebês apareciam no canteiro de repolhos. Até hoje não sei como esta lenda européia chegara aos ouvidos dela. Logo começaram a vir uma série de memórias, como, por exemplo, uma prima grávida e nós, crianças,

\footnotetext{
${ }^{49}$ Cf. Fotos da performance "Passagem". Disponível em: http://arteonline.arq.br/museu/interviews/celeida.htm Acesso em: 22/03/2018, às 19h39.
} 
destroçando um canteiro de repolhos para procurar o seu bebê (TOSTES, 1992). ${ }^{50}$

Em outra entrevista, continua a dizer acerca da importância de sua obra para seu processo artístico:

Passagem foi, para mim, a oportunidade onde mais pertenci a minha matériaprima de trabalho - ao barro, à terra. A Terra como grande ventre, como um cosmos. Preenchi o vazio do pote com meu corpo coberto de barro. Com os sons que saíam de mim, mas não correspondiam a palavras, encontrei o silêncio. (...) Eu tentei fazer a Passagem dois anos antes do que ela foi feita, mas não consegui. Preparava, preparava (...) Quer dizer, preparava, queria, queria, programava e não conseguia fazer. (...) Não estava preparada. E foi uma viagem. Foi uma coisa... eu fiquei doente depois da Passagem. É, eu fiquei doente. Eu comecei a emagrecer, a emagrecer, a emagrecer... eu tinha todas as... tive problemas, assim, de perda de energia, que não tem obrigatoriamente que ver com o barro, nada disso. Se ele é um... o barro, ele gera energia ultravioleta, durante um mês, e eu não atribuí a nada disso. Foi toda coisa da viagem do barro, do contato com alguma coisa, que era muito subterrânea. $\mathrm{O}$ meu próprio processo de vida, o processo de vida muito pra trás, o processo de vida mais próximo. Quando eu digo pra trás, eu estou dizendo pra trás mesmo no espaço; alguma coisa que eu não sei definir, que não sei explicar e não conheço. Mas eu tive contato com alguma coisa muito... como se fosse ali no útero, como se fosse ali no útero. Eu não posso ficar falando isso assim, desse jeito, porque isso é uma experiência, é uma experiência muito íntima (...) Eu acho que eu trepei com o barro, sabe? Como se eu tivesse trepado, como se eu tivesse dado uma trepada, uma trepada com alguma coisa que eu não saberia definir. Foi uma coisa muito, muito importante esse trabalho (TOSTES, 1990). ${ }^{51}$

${ }^{50}$ Entrevista disponível em: http://bibliotecadigital.fgv.br/dspace/bitstream/handle/10438/2146/license.txt?sequence=2 . Acesso em: $19 / 08 / 2018$, às $20 \mathrm{~h} 37$.

${ }^{51}$ ALMEIDA, F. L. Mulheres recipientes: recortes poéticos do universo feminino nas artes visuais [online]. São Paulo: Unesp, 2010. 

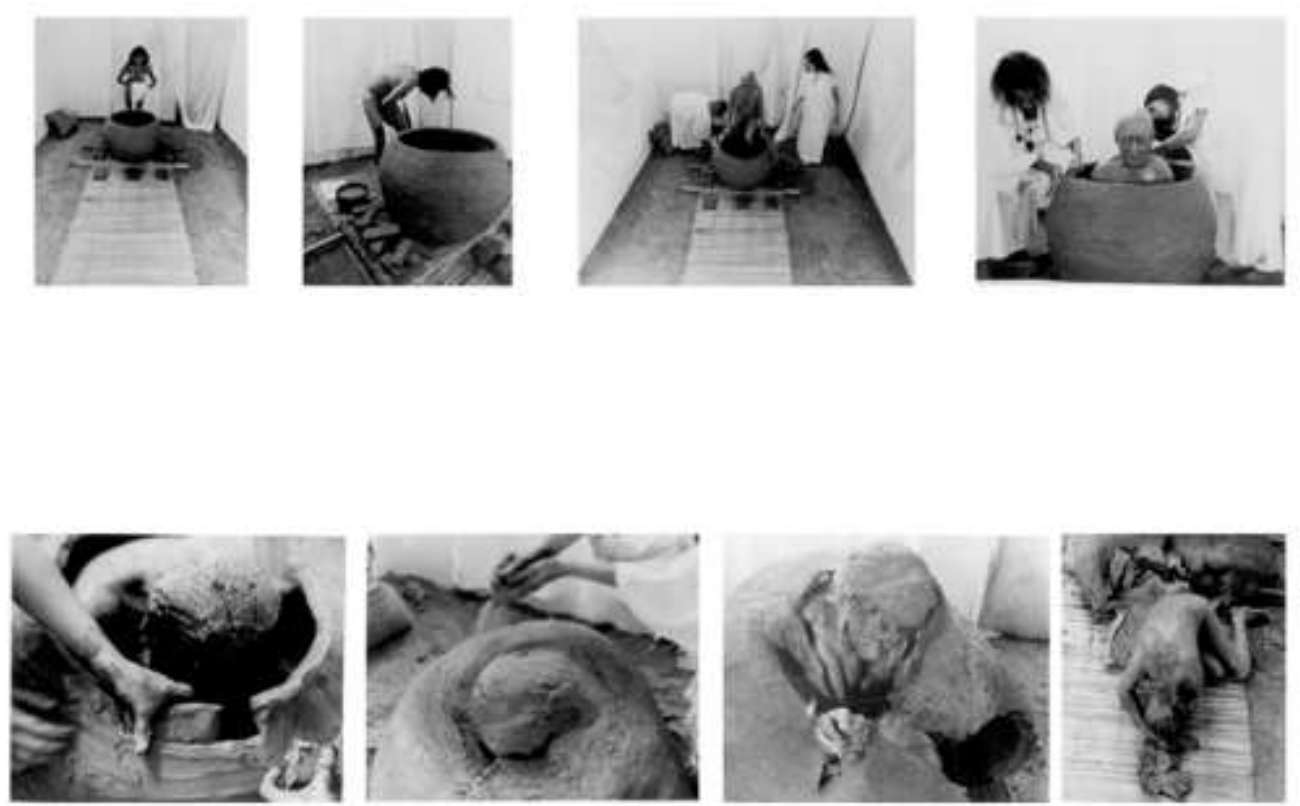

Figura 4. Celeida Tostes (Passagem), Rio de Janeiro, Brasil, 1979. Documentação em performance. Foto: Henri Stahl. Fotos editadas pela pesquisadora.

\subsection{Enfrentamento ou narcisismo?}

Das transições materiais usados para relatar as experiências íntimas autobiográficas que derivam das artes visuais como areia, sangue, barro e terra ou até os dispositivos tecnológicos, apresentam-se como enfrentamento, sobretudo com a roupagem de diagnosticar um corpo enfermo e diferente do corpo saudável apto à reprodução. $\mathrm{O}$ uso indiscriminado da tecnologia não subjaz outros elementos compostos para marcar o gênero na arte, mas apresenta outro atrativo de ferramentas usualmente praticadas no campo e apreço masculinista. A circulação de ações que subvertem a função hegemônica, por vezes calcada numa estética fantasmagórica que tenta dar conta de um corpo além da mística feminina ${ }^{52}$, trouxe a tecnologia como aliada para disseminar a proposta delas.

\footnotetext{
${ }^{52}$ FRIEDAN, Betty. A Mística feminina. Rio de Janeiro: Ed. Vozes, 1971.
} 
A fotografia, através da pose - diferente das modelos - trouxe, para algumas mulheres, inversões de posturas que envolviam o mundo da indústria da moda. As artistas Hanna Wilke, Cindy Schermam, Francesca Woodman, Jo Spence, dentre outras, fizeram uso da nudez como marcador da diferença; decerto, provocar o gênero único trouxe consequências que foram atreladas a um ser ensimesmado. Hanna Wilke, em sua obra Beware of Fascist Feminism (1974), advertia sobre um feminismo que militava contra a sensualidade e o prazer de seus corpos. A transição de materiais representacionais que criticavam a erotização da mulher percorre caminhos diferentes entre Norte e Sul. Enquanto na Europa e nos Estados Unidos a premissa da liberdade sexual, aborto e divórcio estavam em pauta nos espaços de circulação e também nas manifestações artísticas, no Brasil e demais países da América Latina, as manifestações se aproximavam das reivindicações dos direitos humanos e expressão política. Desta forma, poucas artistas residentes na América Latina estavam livres para tal expressão. Ou se expunham fora do seu território, sem jurisdição federal, ou postergavam suas tensões acerca da sexualidade e erotização feminina. Assim, muitas adentraram para questionar a construção do corpo da mulher após o período da repressão (ditaduras). Neste contexto, Liliana Maresca (Buenos Aires, 1951-1994) surge no Processo Nacional de Reorganização da Argentina com obras que expunham seu corpo nu e fetichizado. Desde o ano de 1983, a artista construía narrativas pessoais e íntimas. A radicalização de indícios autobiográficos em suas obras, por vezes, a colocava em um local de atenção. O risco, um dos atributos da performance arte, estavam nas obras de Maresca como ligação da artista, espectador e objeto.

Conhecida por desafiar o destino, Maresca não tinha referência da performance como linguagem, mas, instintivamente, realizava ações que mais tarde foram vistas como performáticas. Portadora do vírus HIV, trouxe a seguinte dúvida: O que resta quando não há corpo? - reflexão a partir do avanço do vírus em seu corpo e as formas de ativar, mesmo em morte, a ideia de um corpo vivo. Através da fotografia, Maresca tenta eternizar seu corpo por meio da permanência da imagem. Esta estratégia também foi utilizada nos movimentos de protesto como documento comprobatório de corpos raptados pela ditadura na Argentina. $\mathrm{O}$ amigo e fotógrafo Marcos López captou as imagens das poses que Maresca realizou para a ação performática Maresca se entrega todo destino. O uso da estética relacional ${ }^{53}$, revela a circulação da erotização do corpo da mulher. O cunho ritualístico, de cura e terapêutico da obra autobiográfica em que a biografada passa por uma tentativa de produção de saúde alude não apenas a uma ação em si mesmo, mas à tentativa de dar forma aos enfrentamentos das

\footnotetext{
${ }^{53}$ BOURRIAUD, Nicolas. A estética relacional. São Paulo: Martins, 2009.
} 
figuras de si. Ao ofertar seu corpo ao espectador por meio de fotografias sensuais com inscrição do seu próprio número de telefone, rompe com a subjetividade, adentrando um jogo sem estratégias bem definidas. O risco do jogo performativo da artista, através do convite e de suas poses sensuais, rompia com o ato testemunhal a partir das fotografias.

Após uma ditadura sangrenta, com desaparecimento de muitos corpos, os argentinos buscavam em suas manifestações artísticas indícios memoráveis de sua população e diversas relações ao corpo. As torturas e corpo de mulheres serviram de foro para criação artística. A principal reinvindicação das mulheres era a guarda indistinta a cada um dos pais, pois muitas, durante a ditadura, tiveram seus companheiros levados pelas forças repressivas e não conseguiram tirar seus filhos do país sem autorização paterna. As hierarquias de gênero fizeram ressurgir o feminismo da pós-ditadura, com duas questões centrais: a violência doméstica e o reconhecimento político. Desta forma, a Argentina foi o primeiro país a sancionar cotas de participação feminina nas listas eleitorais (Lei $\mathrm{n}^{\circ} 24.012$ de 1983) e, mais tarde, 12 países da América Latina obtiveram adesões próximas (BARRANCOS e ARCHENTI, 2017, p. 59). No Brasil, em 1970, o grande movimento de mulheres fez pressão em frente às prefeituras das cidades, reivindicando formas de manterem suas famílias. $\mathrm{O}$ Movimento Feminino pela Anistia, liderado por Therezina Zerbini e com participação intensa de Margarida Genevois, constituiu-se, no país, como marco simbólico para o retorno da democracia.

A reinvindicação das argentinas não somente alavancou as demandas referentes às mulheres na América Latina, como também fez revelar outros processos ainda pouco discutidos: a mulher portadora de doenças autoimunes. Neste sentido, poucas artistas mulheres até os dias atuais revelaram ser portadoras do vírus HIV, numa conjuntura arte/vida. Diferente de artistas homens ${ }^{54}$, que propõem radicalizar essa incidência em suas obras. Talvez, para as mulheres, o vírus tenha uma outra conotação, pois a $\operatorname{AIDS}^{55}$ foi, desde sua

\footnotetext{
${ }^{54}$ Ron Athey, artista que traça diversas vertentes radicais com o corpo, dentre as quais, por ser portador do vírus HIV, criou diversas performances que põe em risco seu corpo. Foi um dos primeiros a assumir a relação do corpo com algum processo infeccioso e, em consequência, foi acusado de jorrar sangue no espaço da ação performática e colocar o espectador em risco. Embora, na ação, o sangue respingado não fosse do artista. Porém, isto fez com que ele ficasse sem trabalhar por longos anos.

55 Em relação à sexualidade, a AIDS, segundo Carole Vance (1995), fez ressurgir abordagens biomédicas da sexualidade. Assim, o interesse da Medicina se expande para novas áreas, como doenças sexualmente transmissíveis, obstetrícia, ginecologia e psiquiatria. As abordagens biomédicas retratam a sexualidade em uma derivação da fisiologia e traçam o corpo através de um funcionamento universal. Os modelos biomédicos são os que menos atendem às categorias do corpo e da saúde. Outro aspecto é o pertencimento de médicos fora do tripé de raça, gênero e classe, que pouco problematiza as categorias homens gays e heterossexuais. Desta forma, suas alianças tendem a estreitar relações com ideologias dominantes. Atribuiu-se erroneamente a doença aos gays e comportamentos sexuais na primeira fase da epidemia da doença, que desviou atenção aos grupos secundários, como prostitutas, usuários de drogas, ou seja, recorre-se a estereótipos para mapear a doença. Os investimentos
} 
descoberta, atrelada aos prazeres marginais e, junto a isso, tipos de sexualidade desviantes foram vistos como disseminadoras do vírus. Em pesquisa realizada no Brasil, os gays masculinos e as prostitutas eram designados como os principais agentes disseminadores; décadas depois, no país, revelou-se que mulheres idosas e casadas contabilizavam maior índice de contaminação da doença; e, mesmo com este dado, a doença ainda é atrelada ao primeiro grupo. Neste sentido, Maresca fez seu corpo mensagem não apenas em relação à sexualidade, mas em plena busca de produção de saúde, pois, portadora do vírus, seu corpo adentra a fronteira da marginalidade.

(...) não seria excesso afirmar que a participação das mulheres brasileiras na epidemia da Aids está marcada mais pela possibilidade de infectarem-se do que por serem elas próprias agentes que contribuam para a expansão da doença no país. Poder-se-ia, inclusive, levantar a hipótese de que o comportamento sexual das brasileiras é um dos fatores que contribuem para a baixa da circulação do HIV na população geral (...) (FERRAZ e GRANGEIRO, 2013, p. 149).

O eixo pendular entre produção de saúde/beleza e os dispositivos dos direitos sexuais produzem normas e legislações sobre a sexualidade. Desta forma, as mulheres, vistas além de belas e reprodutoras férteis, estabelecem outro tipo de mapeamento em que resistir a estes construtos emerge uma geografia do mal.

Segundo Grangeiro e Ferraz (2013), as questões em torno do HIV em mulheres merecem atenção que denotaria um mapeamento do não uso de preservativos, relacionado ao vínculo afetivo com o outro, à influência religiosa e à escolha contraceptiva. Isso detecta também a ineficácia das discussões sobre saúde reprodutiva e pressupõe que a distribuição de métodos contraceptivos (camisinha) deve valer-se da informação de dupla proteção (gravidez e DSTs). Mas antes disso, o combate ao discurso religioso que interfere na vida sexual das mulheres contribui para que alguns métodos sejam pouco debatidos no plano social e também nos avanços das políticas da saúde (aborto).

Diante do avanço do vírus em seu corpo, Maresca consegue extrapolar a esfera de vulnerabilidade da saúde, na urgência da autonomia do corpo, não em função do outro, mas como um marcador da diferença, ou seja, na decisão de seu próprio corpo e de sua vida.

\footnotetext{
financeiros buscam rastrear um perfil como disseminadora da doença; desta forma, os reconhecimentos tardios da sexualidade, em todas as áreas, confrontam as limitações de seus modelos. Cf. VANCE, Carole S. A antropologia redescobre a sexualidade: um comentário teórico. Physis [online]. 1995, vol.5, n.1, pp.7-32. ISSN 1809-4481. Disponível em: http://dx.doi.org/10.1590/S0103-73311995000100001. Acesso em: 27/05/2016, às $20 \mathrm{~h} 55$.
} 
3.6 O espelho do eu

Amelia Jones (1998) fez importante contribuição em Body art performing the subject (1998), ao tratar o narcisismo como uma negociação da retórica no regime do visível. Acrescenta que "a body art deslocou o assunto, não mais investido no objeto, mas implodido no próprio corpo. Os trabalhos passam a projetar o eu para fora através do corpo visível” 56 (JONES, 1998, p.180, tradução nossa). Ainda nas palavras de Jones, o narcisismo em relação à expressão artística das mulheres foi ameaçador para as normas da subjetividade ocidental, uma vez que as ações tornam o corpo da própria artista visível a si. Ao oferecerem seus corpos a diversas expressões (música, fotografia, performance, dança...), fazem circular assuntos atrelados à crítica feminista de forma proativa, em vez de reativa. Ao aproximar a forma proativa das mulheres, parece dialogar com o que já apresentamos por meio de Guausch (2009) como a autobiografia autoprodutiva.

De maneira proativa, Maresca, através das imagens, expõe seu corpo e número de telefone pessoal, dispondo-se a qualquer proposta. Ao mesmo tempo que expõe sua sexualidade e poder, expõe a vulnerabilidade das mulheres diante destes agentes. Em entrevista, a artista contou que recebeu mais de 300 ligações e atendeu apenas algumas. $\mathrm{Na}$ época, a preocupação da artista não era chamar atenção para as questões de gênero, mas criticar o mercado, sobretudo o mercado da arte.

De toda forma, sua proposta ocasionou um lapso de tempo na ação performática, ou seja, perdurou no tempo uma ação do passado. Ao revisitar a imagem, traços da performance podem ser rememorados pela ação causal da fotografia e novas associações, como as questões atreladas ao gênero, podem ser relacionadas com a performance realizada por ela, no passado.

Ao posar sensualmente, Maresca, performatiza para a câmera e seu corpo passa a ser foco. Depois disso, vincula tais imagens a um contato de número de telefone pessoal e,

\footnotetext{
${ }^{56}$ No original: As cited in chapter one, Lea Vergine recognizes as much in her linking of narcissism to the projective capacity of body art: "Projection expels an internal menace that has been created by the pressure of an intolerable impulse and thus it is transformed into an external menace that can be more easily handled. [ In body art projects] the artists shift their problem from the subject to the object, or from the inside to the outside. (...) Because she is a female subject, her narcissism is all the more theartening to the norms of Western subject, since, even while she solicits spectatorial desires throught conventionally heterosexual, codes of female desirability, she also excludes the heterosexual male subject altogether from her selfrelation (we remember Nemesi's fury). Through her myriad, often contradictory presentations of herself, Wilke solicits this gaze, grafting it onto and into her body/self, taking hold of it and reflecting it back to expose and exacerbate its reciprocity. Too, while Wilke has, as we have seen, been criticized as constructing her body as obscene, desirable, and/or victimized object of an inexorable patriarchal gaze, she offered her body ithin a fully theorized array of expressions (objects, interviews, texts, music, performances, photographs) that articulated a proactive rather than reactive feminist subject.
} 
através de uma mídia impressa, faz-se circular em diversos ambientes. As fotografias são vistas como abertura convidativa que, por meio do jornal, veiculam um tempo presente entre o espectador que resolve contatar a artista apto a sanar sua curiosidade. Medeiros (2007) pontua que as imagens mostram três dimensões: "o presente do passado é a memória; o presente do presente é a visão; o presente do futuro é a espera” (MEDEIROS, 2007, p. 65); desta forma, o tempo da performance percorre diversas camadas que ultrapassam o tempo cronometrado pelo presente, seus desdobramentos alçam possíveis relações com o espectador. A fotografia congela o presente e o faz circular, permanecendo como mensagem estática da ação. $\mathrm{O}$ ato de colocar-se à disposição denota a crítica da artista em relação à obra de arte como mercadoria ${ }^{57}$, e analisa também a objetificação do corpo da mulher pela lógica mercantil. Também mostra a vulnerabilidade que o capitalismo impõe às mulheres. Ao se entregar ao destino, muitas mulheres reproduzem a lógica construída através da visão compulsória. $\mathrm{O}$ valor monetário do corpo feminino está presente nas relações de troca e, desta forma, a sedução e o convite da artista criam um deslocamento do eu para um ato relacional com o espectador, a partir dessas implicações.

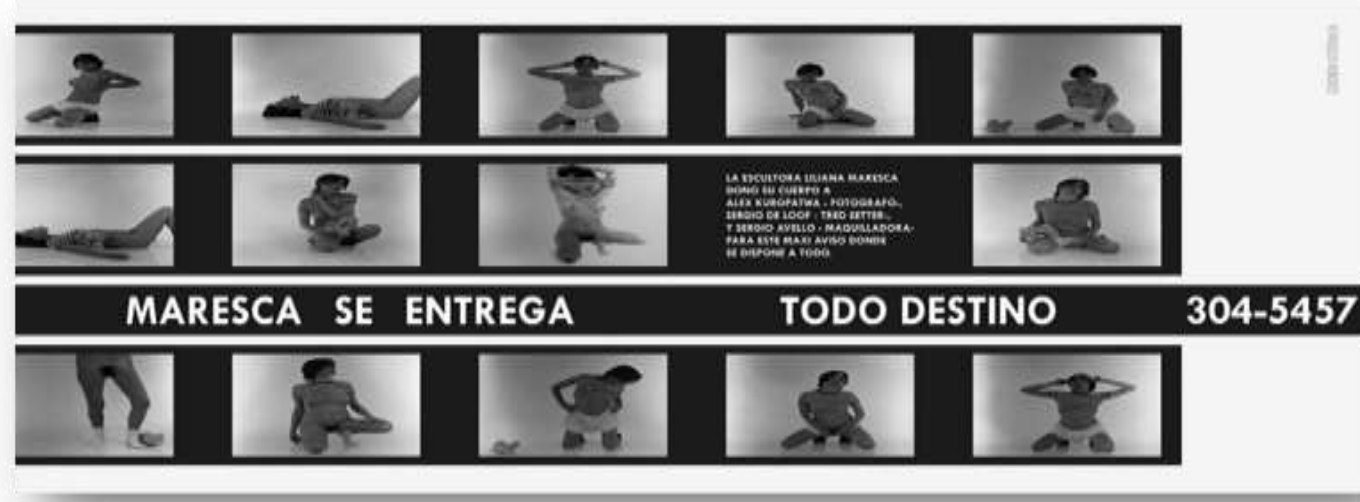

Figura 5. Maresca se entrega todo destino. Foto: Alejandro Kuropatwa. Publicada no número 8 da revista EL Libertino, Buenos Aires, 1993.

\subsection{Mundo íntimo}

Em 1866, Gustave Courbet exibe a obra A origem do mundo e, muito depois disso, as obras de Carolee Schneemann, Interior Scroll (1975), e Annie Sprinkle, A Public Cervix

\footnotetext{
57 Disponível em: http://artistasargentinas-natividadmaron.blogspot.com.br/2013/03/liliana-maresca-poner-elcuerpo.html Acesso em: 29/03/2018, às 16h05.
} 
Announcement (1990-1993), radicalizavam ações em torno da genital feminina, que, por vezes, esbarraram na erotização e, por outras, tornaram-se um marcador da diferença.

$\mathrm{Na}$ atualidade, a crescente busca por estéticas reparadoras que melhoram a aparência vaginal ou reconstroem o hímen (virgindade) e outros ajustes de beleza são recorrentes em clínicas médicas, sobretudo porque muitas mulheres querem presentear seus parceiros com um ajuste $a i^{58}$. Decerto, essas cirurgias de reparação estética são legalizadas pela ordem Médica; no entanto, podem ser mais perigosas do que qualquer ato cirúrgico. O preço por reparo estético da genital fica em torno de 1.000 euros (valor referente à tabela de preço das clínicas portuguesas). O culto à beleza faz do Brasil o segundo país que mais realiza cirurgias estéticas na América, perdendo apenas para os Estados Unidos.

Por muito tempo (e ainda é), existiram tentativas de naturalizar as formas de como a genital feminina é vista. Porém, o esforço por vezes em vão faz com que diversas mulheres não reconheçam seus corpos. A beleza é considerada um traço da feminilidade que regula o sexo por meio do comportamento moral, sexual, e determina um ideal de beleza único.

Em 2004, Regina José Galindo (Guatelama) realiza, em uma clínica clandestina, uma cirurgia de restauração do hímen. A ação durou 30 minutos. Na ocasião, a artista disse ter visto uma reportagem em um jornal que a fez buscar mais informações e, através de um anúncio, chegou a um médico que aceitou realizar a cirurgia de himenoplastia (documentada em vídeo), por certa quantia em dinheiro. Segundo ela, o médico relatou que muitas mulheres reconstruíam o hímen para ganhar status social e que, outras, vítimas do tráfico sexual ${ }^{59}$, eram operadas para valer mais no mercado de mulheres. As meninas virgens, raptadas pelo tráfico, produziam a ideia de proteção em relação a alguma doença sexualmente transmissível ${ }^{60}$.

Depois da cirurgia, Galindo conta que passou mal e teve que ir ao seu médico e, logo que chegou, recebeu um sedativo. Mesmo assim, pôde ouvir as enfermeiras comentarem sobre o procedimento mal realizado. A performance Himenoplastia ${ }^{61}$ propiciou a Galindo o prêmio Leão de Ouro para jovens artistas na Bienal de Veneza, em 2005.

\footnotetext{
${ }^{58}$ Embora saibamos da relação homossexual feminina, trazemos à tona o peso das reproduções compulsória pela ótica hegemônica determinista masculinista e acrescentamos o clareamento vaginal e outras estéticas atreladas a genital feminina.

Disponível em: https://superela.com/cirurgia-na-vulva-feminismo/ Acesso em: 26/08/2018, às $17 \mathrm{~h} 45$.

${ }^{59}$ RUBIN, Gayle. O tráfico de mulheres: notas sobre a "economia política" do sexo. Recife: SOS Corpo, 1993.

${ }^{60}$ Disponível em: https://www.virginitymovie.com/blog/2009/11/artist-regina-jose-galindos-videohimenoplastia-hymenoplasty-and-the-trafficking-of-virgin-girls

${ }^{61}$ Fotos disponíveis em: http://www.reginajosegalindo.com Acesso em: 25/03/2018, às 20h02.
} 

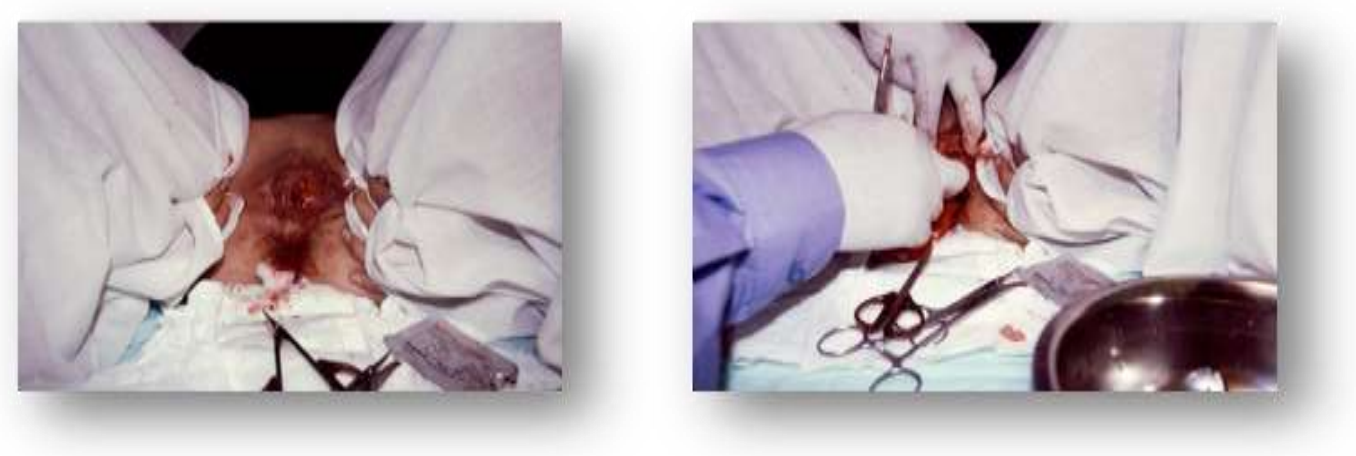

Figura 6. Foto: Belia de Vico.

Nesta ação videografada, Galindo congela a ação no tempo. Todo esplendor da ação está contido nas sequências das imagens que torna seu corpo vivo, fazendo com que o corpo possa "aparecer ou desaparecer, (...) nem morre nem vive de verdade" (JEUDY, 2002, p. 164). O tempo presente, captado pelo vídeo, permite que o espectador, ao assistir em outra temporalidade, insira-se na ação por meio do pacto de fidelização de uma ação ocorrida no passado. Desta forma, a ação permanece no tempo (presente, passado e futuro) e consegue dialogar e sensibilizar o espectador, trazendo a onipresença para o corpo videografado, pois este passa a estar sempre vivo a partir do momento em que o play é acionado.

Galindo, ao colocar seu corpo dentro dos meios regulatórios, aceita o acordo regido pela norma. A complexidade e a contradição dos discursos do corpo fazem valer a importância da historicização das práticas da beleza e regulação. Ao realizar a cirurgia, demonstra que as mulheres, por vezes, estão suscetíveis aos poderes impostos pela beleza. Desta forma, as práticas relacionadas à beleza ou ao culto ao estado de pureza (virgindade) não estão calcadas apenas no consumo, mas na cultura da feminilização, ou suas contradições são nutridas pela manutenção das relações de dominação e subalternização.

\subsection{A casa como memória}

As esferas do íntimo ultrapassam as materialidades imagéticas do vídeo e da fotografia e passam a compor espaços físicos como disparadores da memória e fatos vividos. As diversas linguagens entre o vídeo, a fotografia e os objetos relacionados ao tempo (infância e adolescência) são postos na ação Eu vivi aqui (Brasil, 2012), de Samira Brandão, como dispositivos de fatos memorísticos ocorridos na casa em que nasceu em Bauru, São Paulo. A 
instalação performática conduz o espectador a reviver, junto a ela, momentos que saltam da memória e passam a ser revividos por eles.

Para Lopes (2009), a memória é a raiz dos procedimentos do performer que se faz a partir da imersão interior. Somado a isso, o corpo revela os dilemas e enfrentamentos de cada época, é afetado e manifesta-se. De tal forma, espelha as diversas afetações que envolvem suas lembranças e constituição do humano. Ao traçar outros dispositivos além da lembrança, como constituinte de uma narrativa, Brandão se põe em um espaço de apropriação documental e espacial das suas memórias na casa de sua infância. Ao transpor suas memórias, através da instalação performática, estabelece relação com o espectador, na busca por um campo de forças ${ }^{62}$ que atravessa ao enfrentar vivências do passado em um presente remoto.
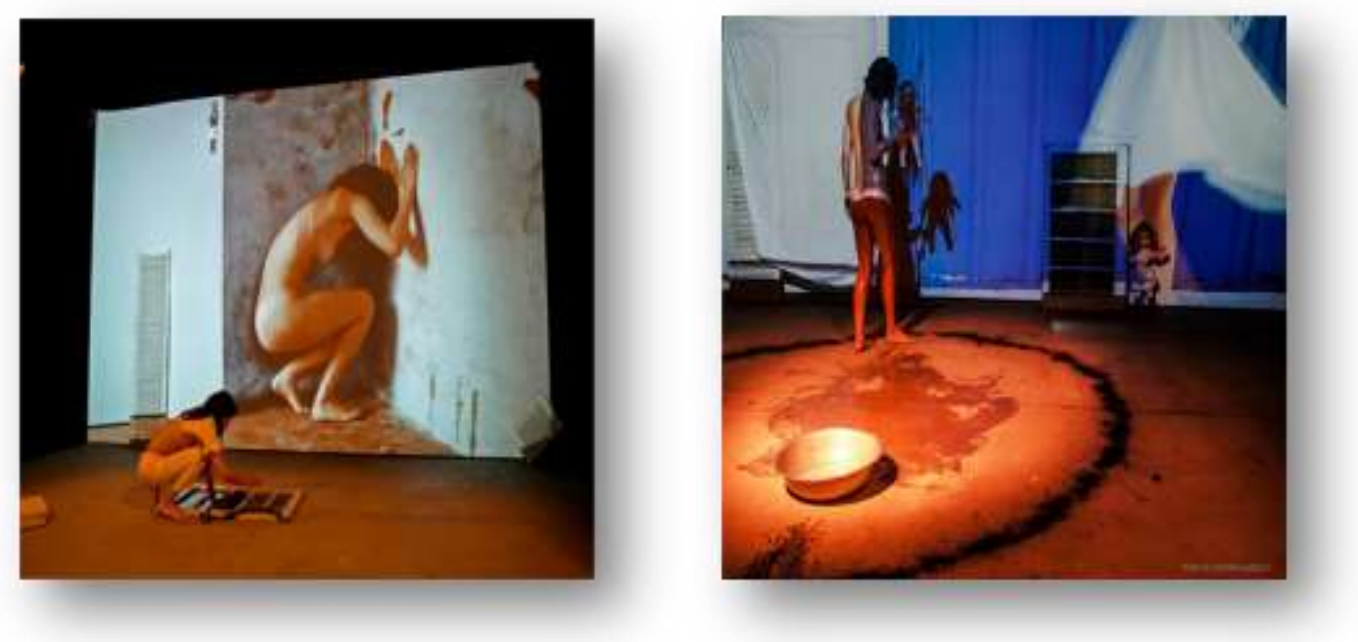

Figura 7. Foto: Antonio Juarez.

O espaço como memória transcende a autobiografia para além do corpo e utiliza o espaço como ativador de reminiscências. A lembrança passa a ser conduzida pelo espaço que concentra diversas instâncias do eu. A relação com outros elementos dispostos no espaço (boneca) reativa fatos de uma infância em um corpo de mulher. Assim como a memória, a fotografia e o vídeo compõem imagens de um outro tempo que, na performance de Brandão, cruzam e presentificam a ação.

\footnotetext{
${ }^{62}$ LOPES, Beth. A performance da memória. Sala Preta, Brasil, v. 9, p. 135-145, nov. 2009. ISSN 2238-3867. Disponível em: https://www.revistas.usp.br/salapreta/article/view/57397/60379 Acesso em: 04/04/2018.
} 
Preciado $^{63}$ (2013) apresenta, através do documentário Whomanhouse (1972), uma análise sobre a construção do ambiente doméstico como espaço de encenação. Declara que as práticas artísticas permitem entender as possibilidades de emancipação (sexual e política). Acrescenta que, ao construir uma narrativa autobiográfica (coletiva ou individual), dispara-se um processo cognitivo e somático. Na ideia de Preciado, o dispositivo de resubjetividade é capaz de produzir outro sujeito, outra consciência e outro corpo. A elevação do espaço doméstico - malsinado injustamente como clichê, acrescenta - é utilizado para questionar estigmas e denúncias no surgimento de novas técnicas e biopolíticas higiênicas que adentram o corpo. A “crítica ao espaço doméstico como uma tecnologia de produção e dominação do corpo feminino e das instituições matrimoniais e sexuais como regimes de confinamento e disciplina"64 (PRECIADO, 2018, tradução nossa) podem ser diagnosticadas pela instalação que vai ao encontro da obra de Tostes (Passagem), com seus corpos cobertos de barro. Ambas, Brandão e Tostes, não somente remetem ao rito de renascimento e purificação, como ao corpo disciplinado que deve estar limpo e saudável. Em uma das estações da casa, Brandão lava seu corpo com água contida dentro de uma bacia. O espaço marcado com terra, em formato circular, uma espécie de círculo de purificação, rompe o corpo de menina para o corpo de mulher. Pedaços de janelas e bonecas, distribuídos na parte exterior do círculo, denunciam olhares eróticos que aprisionam as mulheres dentro de seus próprios corpos. As vestimentas longas, janelas fechadas, formas de resguardar a intimidade para não provocar a volúpia do Outro fazem parte da construção cultural e social das mulheres.

São materializadas na ação crítica aos limites disciplinares que transitam entre a arquitetura e a vestimenta que ditam formas e conduções dentro do ambiente doméstico; a condução arbitrária e social - por meio da reprodução compulsória familiar - determina e controla as diretrizes do corpo da mulher, seja no ambiente doméstico (privado) ou fora dele (público). Neste sentido, a memória se torna um documento vivo ${ }^{65}$ que se vale de fatos

\footnotetext{
${ }^{63}$ No original: El documental Womanhouse cambió mi forma de pensar la práctica artística y me hizo entender que era posible transformar la universidad y el museo en espacios de emancipación sexual y política (...)hacia el arte entendido como proceso de emancipación cognitiva y somática. (...) El objetivo del arte ya no es producir un "objeto," sino inventar un dispositivo de re-subjetivación que sea capaz de producir otro "sujeto": otra conciencia, otro cuerpo.

Disponível em: http://lemagazine.jeudepaume.org/blogs/beatrizpreciado/2013/10/03/volver-a-la-womanhouse/ Acesso em: 04/03/2018, às $15 \mathrm{~h} 14$.

${ }^{64}$ No original: crítica del espacio doméstico como tecnología de producción y dominación del cuerpo femenino $y$ de las instituciones matrimoniales y sexuales como regímenes de encierro y disciplina. Disponível em: http://lemagazine.jeudepaume.org/blogs/beatrizpreciado/2013/10/03/volver-a-la-womanhouse/. Acesso em: $04 / 03 / 2018$, às $18 \mathrm{~h} 14$.

${ }^{65}$ SOLER, Marcos Marcelo. O campo do teatro documentário: morada possível de experiências artísticopedagógicas. 2015. Tese
} 
passados para denunciar aprisionamentos e construtos sociais que encarceram corpos subservientes em modos de existir calcados na reprodução arbitrária e compulsória. Assim, a reprodução destas ordenações no ambiente doméstico e familiar criam um círculo de continuidade normativa ancorado pelas arquiteturas que servem de confinamento para essas ordenações perdurarem.

\subsection{Relações familiares}

A família passa a ser outra vertente das questões atreladas ao eu. Diante de relações tão dispares, as figuras materna e paterna aparecem nas manifestações como um lugar por um lado terapêutico e, por outro, de denúncia. No que concerne à categoria mulher, os embates denotam em demasia um local de denúncia ao invés de cunho terapêutico, embora um não isente o outro. Algumas manifestações se pautam na denúncia como vingança de atributos ocorridos, e as ações performáticas colocam o familiar em um espaço de risco e consternação.

Pilar de La Fuente, em Entierro y desentierro de mi padre (Mexico, 2004), enterra seu pai biológico com intuito de soterrar as regras impostas em sua educação familiar. Mostra a relação paternal imbuída de duras implicações domésticas envolvendo o poder do pai de família na educação das filhas. Assim como o ambiente doméstico silencia uma educação arbitrária, reproduzida compulsoriamente pelos pais, outras derivações, como violências incestuosas $^{66}$, pairam no ambiente privado. Por medo, muitas mulheres, ainda meninas, não conseguem denunciar seus familiares (co)sanguíneos ou não. Ao enterrar seu pai, Pilar se desvencilha das regras e ordenações implicadas na sua educação. Deslocando o peso que soterra qualquer possibilidade de fuga desses construtos, ao enterrar o pai, com areia, aterra o corpo masculino que pesou em sua vida.

A ação convida o pai da artista a dividir o peso da educação paternalista imposto pela construção social. E, em cada pá cheia de areia, o peso arbitrário recai pelos grãos de areia em um processo de responsabilização (BUTLER, 2015).

(Doutorado em Pedagogia do Teatro) - Escola de Comunicação e Artes, Universidade de São Paulo, São Paulo, 2015.

Doi:10 11606/T27 2015 tde-24112015- 104357.

Acesso em: 23/05/2017, às $14 \mathrm{~h} 20$.

${ }^{66}$ Em 2017, o livro Diário de um incesto, de autora anônima, foi um dos mais procurados nos Estados Unidos. As críticas em relação à grande demanda e procura do livro se atenta para a contribuição do imaginário dos pedófilos, que podem ver na literatura um alimento para suas atrocidades. 


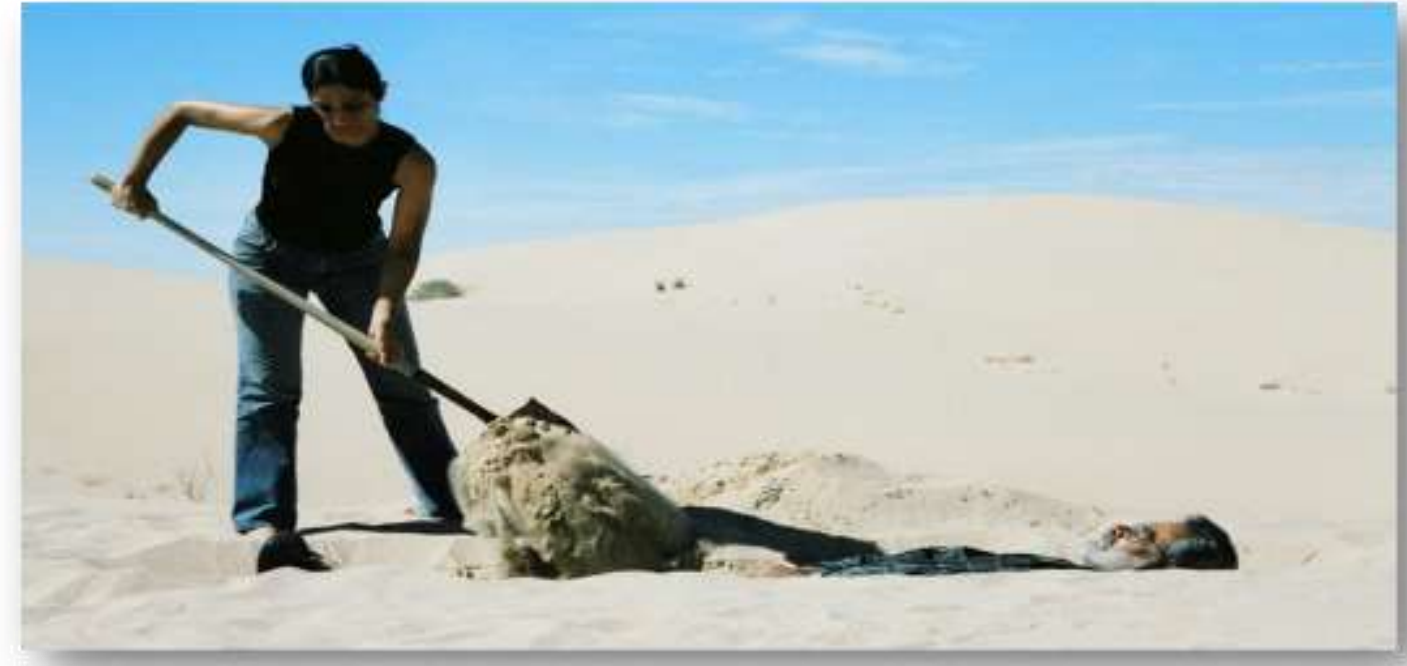

Figura 8. Foto: Antonio Juarez. 


\section{TERRITÓRIOS POLÍTICOS}

4.1 Latinidades

Uma vez me ofereceram fazer uma crônica de comentários sobre acontecimentos, só que essa crônica seria feita para mulheres e a estas dirigida.

Terminou dando em nada a proposta, felizmente. Digo felizmente porque desconfio de que a coluna ia era descambar para assuntos estritamente femininos, na extensão em que "feminino" é geralmente tomado pelos homens e mesmo pelas próprias humildes mulheres: como se mulher fizesse parte de uma comunidade fechada, à parte, e de certo modo segregada. (Clarice Lispector) 
se engravidar

faço abortos

por muito

que me custe

e custa-me

muito

$[\ldots]$

(Adília Lopes)

Embora saibamos da relação entre as escritas de si e autorrepresentação com o narcisismo e a cultura midiática, alertada por Sibilia (2016), aproximamo-nos dessas manifestações por meio da guinada subjetiva apoiada pelo contexto sociopolítico da América Latina, mais precisamente na Argentina e Brasil. Ao passo que detectamos acontecimentos e fatos ocorridos na Argentina como sintomas próximos relacionados às políticas públicas e manifestação ativa das mulheres, em épocas diferentes, no Brasil.

A organização das mulheres frente aos diversos atravessamentos de desestruturação familiar, empregabilidade, direitos reprodutivos, espaços de circulação e muitos outros as deslocaram da casa para a rua, em um motim de luta e representatividade (protagonismo), em ações que buscavam respostas e avanços frente às emergências apontadas por elas. As teatralidades ou performatividades políticas (CABALLERO, 2009) acolheram testemunhos e documentos, a partir do clamor pessoal como dispositivos estéticos compondo novos modos de construção de discursos em movimentos reivindicatórios. Neste sentido, o uso da memória traumática $^{67}$ (TAYLOR, 2013, p. 235) implicava, ao ouvir o outro, responsabilidade de coproprietário (TAYLOR, 2013, p. 235), ou seja, a fala pessoal eclodia e reverberava de diversas maneiras no coletivo, mas não como agente paliativo da dor, pois a perda era irreversível. A ditadura sangrenta na Argentina (1976-1983) aumentou a quantidade de mulheres em movimentos de protestos. Em busca de resposta aos desaparecidos (filhos, companheiros, amigos e outros de ordem parental), as mulheres da América Latina desenvolveram modos resistentes de organização que marcam a inserção da performance arte nas manifestações com indicativos de teatralidade e performatividade política. É por meio da

\footnotetext{
${ }^{67}$ Para Taylor, neste contexto, a performance não aborda apenas a memória traumática pessoal, mas extrapola a individualidade e alça o coletivo, a partir da denúncia política. Ao reivindicar, o pessoal é pulverizado pelo coletivo, que reativa o passado através da ação coletiva que revela as atrocidades ocorridas no passado.
} 
dor singular delas que os arranjos estéticos são melhor absorvidos num direcionamento que, mais tarde, desponta no artivismo ${ }^{68}$.

Desta fractura sanguínea, causada pela ditadura na Argentina, muitos desaparecidos, dentre eles filhos dessas mulheres, tornaram-se principal foco de luta que desencadeou na resistente organização de mulheres até os dias atuais. Exigindo resposta ao regime da época a respeito da localização dos desaparecidos (seus filhos), as Madres da Plaza de Mayo (1977) iniciaram suas atividades com poucas mulheres (14) e, de duas em duas, de braços dados, caminhavam ao redor da Plaza como disrupção à imposição e proibição de encontros públicos lançada pela ditadura. Os lenços brancos amarrados ao redor da cabeça as identificavam uma vez por semana, às quintas-feiras, em um processo único de protesto político performático que logo alastrou-se por todo o país.

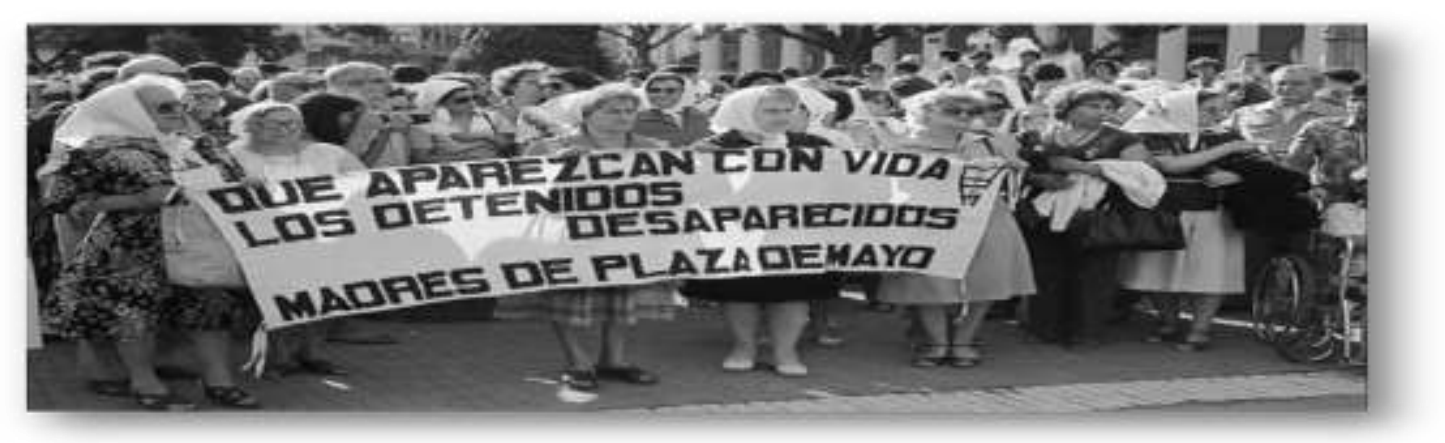

Figura 9. Fonte: https://medium.com/revista-subjetiva/m\%C3\%A3es-que-lutam-2581aa26bbda Acesso em: 14/07/2018, às $15 \mathrm{~h} 47$.

A autobiografia, constituída de dor e sofrimento, sustentada pela tensão e abuso de poder, salta da singularidade para o luto público coletivo. As Abuelas e Madres ${ }^{69}$, com mais de 40 anos de atividades, mantêm a Asociación Madres de Plaza de Mayo ${ }^{70}$ e Abuelas de Plaza de $M_{a y o}{ }^{71}$ como organizações criadas por mulheres na luta por direitos humanos fragilizados no período da ditadura militar no país. As Abuelas surgiram depois que as mães de mulheres grávidas, raptadas durante o regime militar, começaram a dar conta de que não veriam seus netos e, desta forma, toda Abuela é uma madre duplamente violada.

\footnotetext{
${ }^{68}$ Definido por Lemoine e Quardi na combinação entre arte e ativismo político em que as instâncias envolve resistência cultural, politica, ecológica, social e espiritual. Cf. LEMOINE, Stéphanie. OUARDI, Samira. Artivisme: Art, action politique et résistance culturelle. Paris: Éditions Alternatives, 2010.

69 Optamos por deixar em espanhol (argentino) as palavras "avó" e "mãe", para atrelar o percurso histórico dessas mulheres que mantêm mais de 40 anos de luta e formação de uma associação de direitos humanos.

${ }^{70}$ Associação Mães da Praça de Maio (tradução nossa). Disponível em: http://madres.org/index.php/consignas/.

${ }^{71}$ Disponível em: https://www.abuelas.org.ar/.
} 
Em 1972, o Movimiento de Liberación Feminista (MLF) teve participação da artista e fotógrafa militante Ilse Fusková ${ }^{72}$. Nesta fusão, indícios artísticos começaram a compor essas reivindicações. Este motim organizacional das mulheres argentinas exemplifica a onda de lutas e reivindicações sociopolíticas na América Latina. A vizinha portenha não apenas inflama tais lutas, como por meio do ativismo das mulheres traz rastros autobiográficos que mais tarde contaminam a arte. Neste aspecto, a vida humana toma força motriz no fazer ver dentro do espaço de circulação que insiste em invisibilizar as mulheres e suas reivindicações. Neste encontro, a autobiografia não serve apenas à singularidade, mas é testemunhal no processo explosivo do coletivo, fortalecendo as manifestações populares. A somatória das estratégias aumenta a visibilidade nacional através da combinação potente das linguagens artísticas.

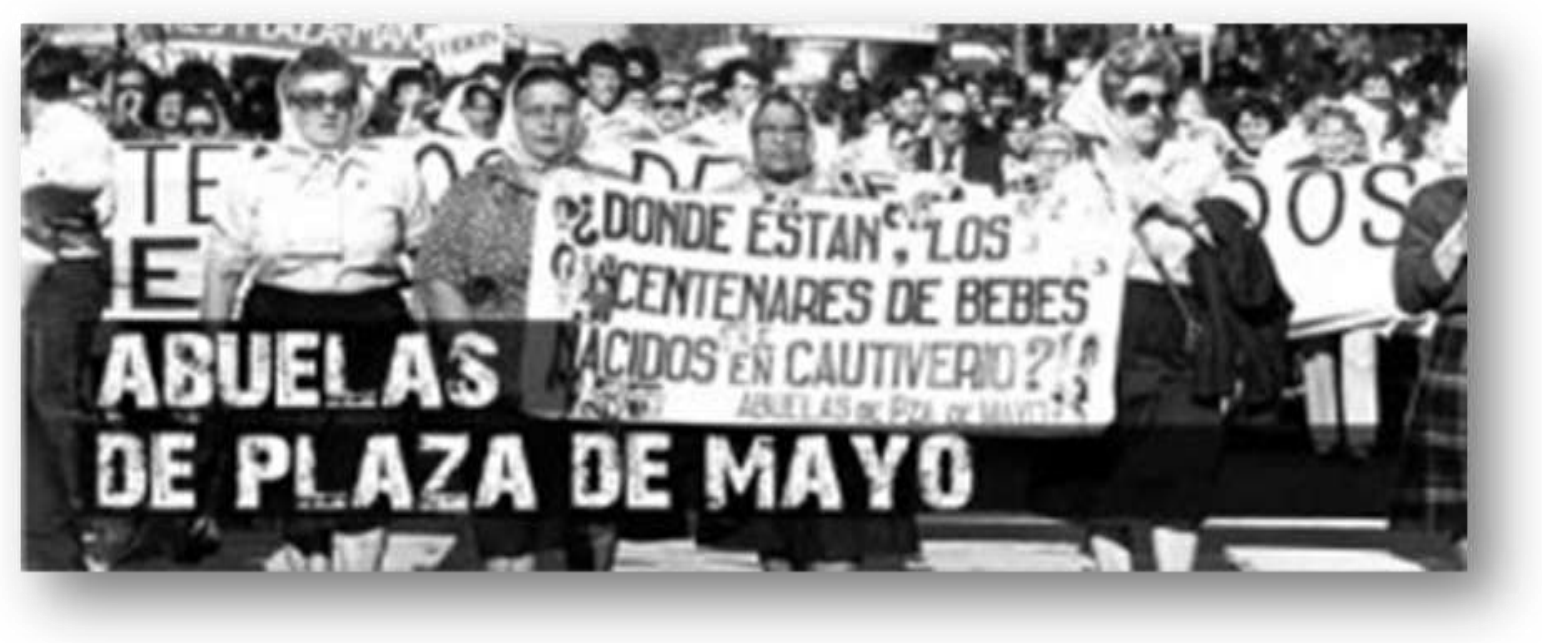

Figura 10. Fonte: https://pensamento.org/longform/argentina-ecos-e-vozes-o-pacificador-a-ativista-e-o-guerrilheiro/. Acesso em 14/07/2018 às 15:55.

O campo minado da autobiografia na fronteira entre arte e vida conduz narrativas que partem da esfera pessoal, numa tentativa "que revela o sinistro cotidiano e onde o obsceno funciona por transbordamento, pela incidência do real contextual - inclusive, a partir do não dito - na evocação de uma memória de violência" (CABALLERO, 2011, p. 111). Na manifestação das Madres, a proibição dos militares as fizeram utilizar lenços brancos (fraldas usadas por elas como lenços envolta de suas cabeças, na alusão às vidas de seus filhos desaparecidos), que simbolizam os corpos ausentes na presentificação dos desaparecidos

\footnotetext{
${ }^{72}$ Ativista argentina atuante na área fotográfica, que em rede pública foi a primeira mulher, no país, a declarar-se lésbica. Atuante no movimento feminista lésbico da Argentina.
} 
como duplo pictórico (CABALLERO, 2011, p. 123). Para Caballero (2011), o uso dos lenços brancos foram estratégias simbólicas diante da fragilidade de expressão popular na junção de elementos como fotos dos desaparecidos. "As estratégias, como as pessoas, têm histórias. Nesse caso, as estratégias fazem reaparecer as que foram apagadas da própria história" (TAYLOR, 2013, p. 237). As personagens sociais representadas pelas Madres de Plaza de Mayo, segundo Caballero, tornaram-se ícones. Algumas desaparecidas outras fortemente reprimidas em praça pública se configuraram em personagem simbólico; e, no campo visual, o uso do lenço, sem rosto, compõe obras visuais. O lenço recentemente foi atualizado para a cor verde, na Campanha Nacional pelo Direito ao Aborto Legal, Seguro e Gratuito, acampado por mais de 500 organizações e movimentos feministas.

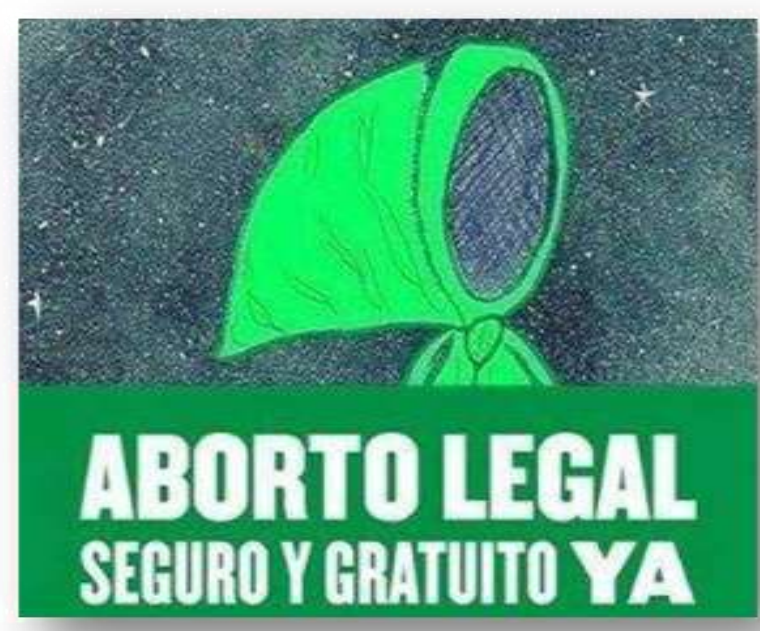

Figura 11. Foto reprodução.

Além do lenço como atributo do campo visual, durante os protestos, a repetição da ação das Madres e Abuelas em dias da semana (quinta-feira) "contribuíram com novos elementos para a problematização das relações entre política e estética" (CABALLERO, 2011, p. 124), que foram aperfeiçoados pelo H.I.J.O.S, que nasce em busca de respostas parentais sobre suas existências, em decorrência do período ditatorial.

\subsection{Movimentos de protesto}

Em sua narrativa, na Argentina, ao encontro do grupo de jovens H.I.J.O.S $S^{73}$ (os filhos dos desaparecidos), Taylor (2013) acrescenta a denúncia escrachada e o uso de cartazes, fotografias, faixas e música estrondosa (rock) na somatória de composição da linguagem estética que ela designa como teatral. O grupo, composto por mulheres e homens, surgiu em 1995, em consequência da ditadura militar no país. Após sequestro de pessoas adeptas aos

\footnotetext{
${ }^{73}$ Disponível em: http://www.hijos-capital.org.ar/ Acesso em: 10/04/2018, às 12h06.
} 
ideais de esquerda, muitos dos capturados tiveram seus filhos adotados por famílias de militares. As mulheres que deram à luz em cárcere também tiveram seus filhos adotados pelos militares. A resposta ao paradeiro dos pais dessas crianças ainda é uma incógnita. Nesta trama, as crianças que descobriram que seus pais foram vitimados durante o regime militar criaram, já adultos, uma rede em busca de resposta aos desaparecidos. Como desdobramento geracional das Madres e Abuelas, os H.I.J.O.S contam com artistas ativistas traçando, na cidade de Buenos Aires, um campo visual de denúncia das atrocidades ocorridas no país. O grupo Arte Callejero, que atua em conjunto com os H.I.J.O.S, acopla, nas placas de rua, imagens dos desaparecidos próximas às casas ou locais de passagem das pessoas ligadas ao regime militar na época. Antecedendo as grandes manifestações, com acentuação no ano de 2001, os H.I.J.O.S dão forro às outras manifestações de insatisfação popular e, neste estopim populacional, apoiam e atuam em prol de outras pautas referentes aos direitos humanos no país, principalmente na crise de 2001, na qual houve diversas manifestações detonadas na Argentina.

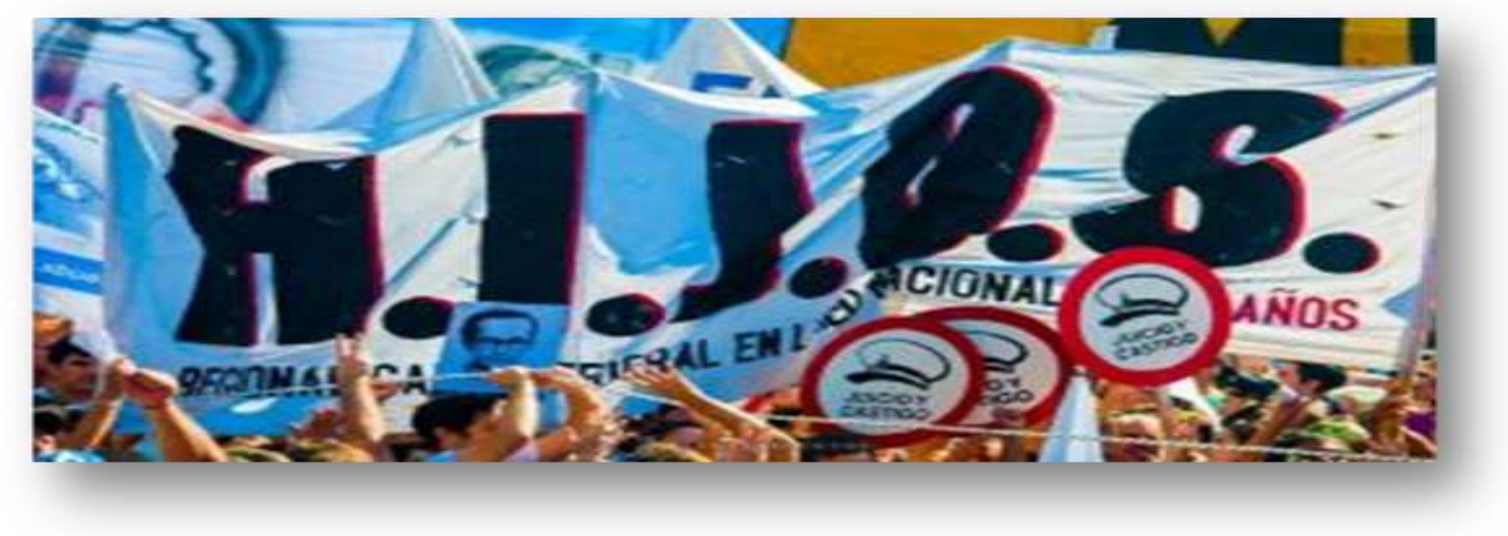

Figura 12. Disponível em: http://www.hijos-capital.org.ar/. Acesso em: 14/07/2018, às 15h25.

É justamente neste ponto da crise da Argentina (2001) que desenhamos todo nosso percurso até aqui, para salientar as relações sociopolíticas da Argentina e Brasil. As expressões autobiográficas que despontam da influência sociopolítica servem de análise para olhar as escritas de si, autorrepresentação e os mais variados desdobramentos presentes nas pesquisas, como tentativa de trazer à tona identidades violadas e a urgência de tentar avançar em direitos humanos fragilizados nos países da América do Sul. Na Argentina (ano de 2001), o arrolho econômico de equiparar o peso argentino ao dólar americano e as concessões agrícolas dadas pelo governo às indústrias nacionais que, por sinal, competiam com as do 
Brasil, não foram suficientes para manter o equilíbrio da economia do país nem tampouco satisfazer e curar a insatisfação dos argentinos em relação às atrocidades e violações de direitos que se intensificou com o declínio econômico.

O ex-presidente peronista Carlos Menem ficou no poder de 1989 até 1999 e foi muito criticado ao perdoar ex-ditadores, agravando ainda mais a insatisfação popular. Seu sucessor, Fernando de la Rúa, no poder de 1999 até 2001, trazia para o povo argentino uma possibilidade de avanço econômico, mas nos primeiros dias de seu mandato enviou projetos que visavam desregulamentar as condições trabalhistas. Numa tentativa de enfraquecer os sindicatos, a primeira versão do projeto foi malvista e, só depois de modificações, o projeto trabalhista conseguiu aprovação por intermédio de aliados subordinados. Mesmo assim, a crise piorou depois que o presidente dos Estados Unidos tomou posse, George W. Bush, em janeiro de 2001. E o atentado de 11 de setembro, em Nova Iorque, fez com que Bush modificasse a política para países devedores, agravando ainda mais a crise hermana. Diante desses acontecimentos, a população tomou as ruas e as interfaces entre movimentos reivindicatórios e estratégias estéticas, com auxílio das linguagens artísticas, começaram a somar pelo uso de dispositivos e manuseio de materiais do cotidiano, para denunciar a insatisfação popular. $\mathrm{O}$ cacerolazo $^{74}$, também presente nas manifestações ocorridas no Brasil em 2016, foi marcado pelo uso de panelas para expor a insatisfação com o governo. Em outro contexto, o panelaço no Brasil alimentava a elite brasileira, insatisfeita com os avanços da economia para a população de baixa renda e o deslocamento de grupos não hegemônicos na busca por direitos. Por meio do som emitido pelas panelas, em suas varandas, localizadas em edifícios de classe alta das cidades do Brasil, a população batia panelas para indicar insatisfação governamental. A classe média brasileira causava arruaço em seus apartamentos.

No contexto brasileiro, neste período (2003-2016), as mulheres (negras ${ }^{75}$, indígenas ${ }^{76}$ ) viram chance de dialogar por possíveis avanços de direitos e expansão nos espaços de

\footnotetext{
74 Panelaço na tradução (português do Brasil), ou cacerolazo ou cacerolada (espanhol) é a utilização de utensílios domésticos como panelas, frigideiras etc., no intuito de combater, através da ação de bater panela, as insatisfações sociais. Tática, dos anos 70 no Chile, usada pelos opositores do socialista Salvador Allende, como artificio de insatisfação. Usada também contra a presidenta no Brasil (Dilma Rousseff), no contexto da gourmetização das insatisfações das camadas elitizadas das capitais brasileiras.

${ }^{75}$ Eva Blay (2017) relembra que as mulheres negras estiveram na organização e atuação, criando entidades especificas, como Geledés no Brasil (1985). Cf. BLAY, Eva Alterman e AVELAR, Lúcia. 50 anos de feminismo: Argentina, Brasil e Chile: A construção das Mulheres como atores políticos e democráticos. São Paulo: Ed. Fapesp, 2017.

${ }^{76}$ Há, durante a governabilidade do Partido dos Trabalhadores (PT) no Brasil, um falso avanço das demarcações de terras indígenas. No qual, em seus primeiros anos de mandato, o ex-presidente Luíz Inácio Lula da Silva (2003-2010) demarcou terras que não apresentavam conflito com fazendeiros. Quando as possíveis demarcações de terra sofriam este impasse, o Governo Federal não enfrentou a bancada ruralista, a fim de expandir as demarcações. Fonte: https://www.socioambiental.org/pt-br. Acesso em: 15/07/2016, às 23h13.
} 
circulação (empregabilidade), que até então (e ainda é) eram majoritariamente constituídos por homens brancos ou representantes da classe alta.

O reconhecimento, impulsionado pelas políticas públicas que apoiavam grupos não hegemônicos, permitiu que muitos brasileiros fruíssem de conquistas, como direito a ingressar em curso superior, redução de taxas em bens primários (gás, leite, transporte gratuito etc.). Esta política certamente fortaleceu grupos estigmatizados que aos poucos foram conquistando avanços educacionais, trabalhistas, e tensionaram a circulação entre seus pares. É neste avanço que as mulheres passam a reorganizar-se com aliadas (representantes governamentais) ${ }^{77}$, a fim de fortalecer suas reivindicações. Com maior autoestima, os grupos marginalizados viam, nesta política aplicada pelo PT (Partido dos Trabalhadores), maior adesão e resistência. Jovens negras, indígenas e trans começam a usar suas autobiografias, muitas vezes marcadas pela violência, como dispositivo de representatividade, no intuito de disputar

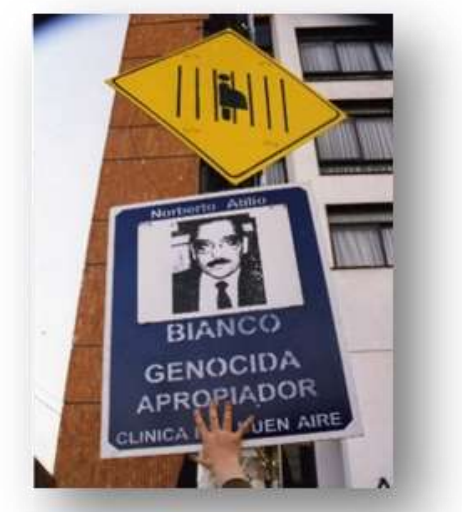

Figura 13. Fonte: Divulgação o espaço de fruição que adentra a empregabilidade, níveis educacionais etc. E, como dívida a seus pares, começaram a trazer à tona a ausência dessas representatividades nos espaços de circulação. As políticas da diferença, o lugar da fala e a representatividade veem a autobiografia como alicerce producente nas lutas das diferenças. Neste contexto, amparadas pelo campo dos movimentos feministas, estrondam, em 2012, a partir da influência da tríade de presidentas - Dilma Rousseff (2010/Brasil), Cristina Kirchner (2007/Argentina) e Michelle Bachelet (2006/Chile) - uma tentativa reivindicatória de novos espaços de representação.

A arte, embebida pela fonte da vida, se vê afetada pela crítica social que restringe as mulheres aos espaços de poder. Neste afã, a autobiografia se alia à busca por espaços de atuação e detona, como material propulsor in situ, diversas manifestações que visam apontar a ausência de alguns corpos na estrutura de representação artística e social. As linguagens artísticas (teatro, dança, artes visuais, cinema, circo, música, performance etc.) tentam, de maneira tímida, alinhar essas ausências, trazendo temas relevantes a estas representações.

Diferente do que houve no Brasil em 2016, o panelaço datado em 2001 na Argentina trouxe à tona o rito coletivo (CABALLERO, 2011, p. 125), com propósito de revelar um

\footnotetext{
${ }^{77}$ Destacamos, em outros períodos, Ruth Escobar, com o grupo Frente de Mulheres Feministas (FMF), depois MDB, hoje PMDB (Partido do Movimento Democrático Brasileiro), assim como Marta Suplicy e Carmem Barroso, do PT (Partido dos Trabalhadores) e Conceição de Jesus, do PCDB (Partido Comunista do Brasil).
} 
discurso imbuído pela sonoridade das panelas, por meio de elementos carnavalescos subversivos, novas formas de expressão. Sobre isso destacamos:

Recorrentes em quase todas as manifestações daquele período, os panelaços converteram-se em "gesto conector", dimensionados como ritos de resistência da sociedade civil numa "nova forma de política lúdica"!". Considero a ação de levar às ruas apetrechos culinários e transformá-los em instrumentos de percussão (batendo com colheres, garfos e tudo o que servisse para gerar uma "sonoridade sem palavras") como subversões carnavalescas que fundaram communitas lúdicas e anárquicas.

Esta 'encenação do mundo às avessas' me permite evocar situações carnavalescas da teatralidade de Aristófanes na qual os protagonistas esgrimem seus utensílios de cozinha como armas marciais!". Nas cenas de 2001, as panelas viradas e vazias representavam com gestos e golpes o estado de coisas'.

O que designo como "teatralidade" dos panelaços':" está vinculado à ocupação do espaço por um pathos e uma energia extracotidiana, uma espécie de coro dionisíaco impulsionado pela vontade de representar um único texto: o desacordo generalizado com o roubo praticado pelo Estado. As performances cidadãs foram, sobretudo, "acontecimentos de convívio", que promoveram nos cenários públicos uma transformação simbólica do cotidiano e uma nova forma de discurso não verbal (HALAC, 2002, p. 18), sendo também produtoras de um "acontecimento de linguagem". Na apropriação de estratégias cênicas por uma comunidade que explorou novas formas de expressão, observo a emergência de liminaridades pelo entrecruzamento de gestos cidadãos e de configurações simbólicas, gerando uma estilização das ações políticas, mas sobretudo pela produção de um estado de anarquia coletiva, de um pathos líminar" e pelo fato de pôr em prática dinâmicas de inversão temporais que carnavalizam o status quo (CABALLERO, 2011, p. 125-126).

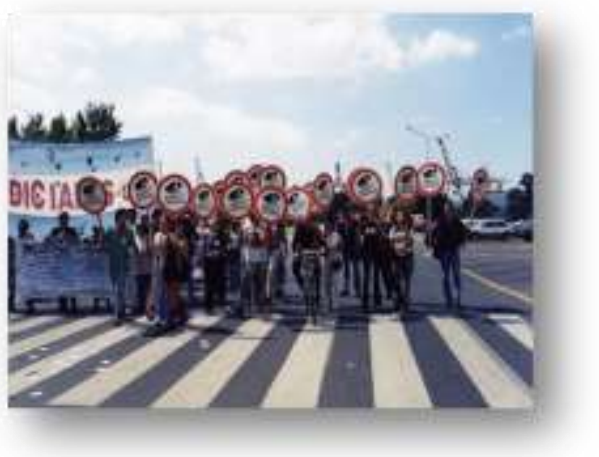

Figura 14. Fonte: Divulgação.

A forma festiva e carnavalesca dos H.I.J.O.S, por meio de rechaços teatralizados, organiza e direciona os envolvidos para locais que circulam os agressores. Neste aspecto, existe aprofundamento prévio das ações, a partir do mapeamento da rotina desses agressores (impunes), em estratégias de identificar locais clandestinos que aconteciam torturas. Aos que acompanham os protestos, há uma espécie de revelação dessas evidencias, que concede aos manifestantes um papel de júri popular. Em 2001, as cidades da Argentina se encontraram em um boom de manifestações em detrimento da crise. As Madres, Abuelas e H.I.J.O.S receberam, durantes os protestos, grupos de artistas e ativistas que buscavam, com recursos captados das linguagens artísticas, materializar 
simbolicamente a crise. Neste momento, as estruturas simbólicas trazidas pelos grupos ${ }^{78}$ Arte Callejero (GAC) e Etcétera (ETC) somam na composição, ao utilizarem elementos de indicação urbana (placas) na contraversão de seu uso. Neste sentido, a alusão referente à impunidade garantida aos militares fez compor, nas placas de rua, indicativos com palavras: castigo e julgamento.

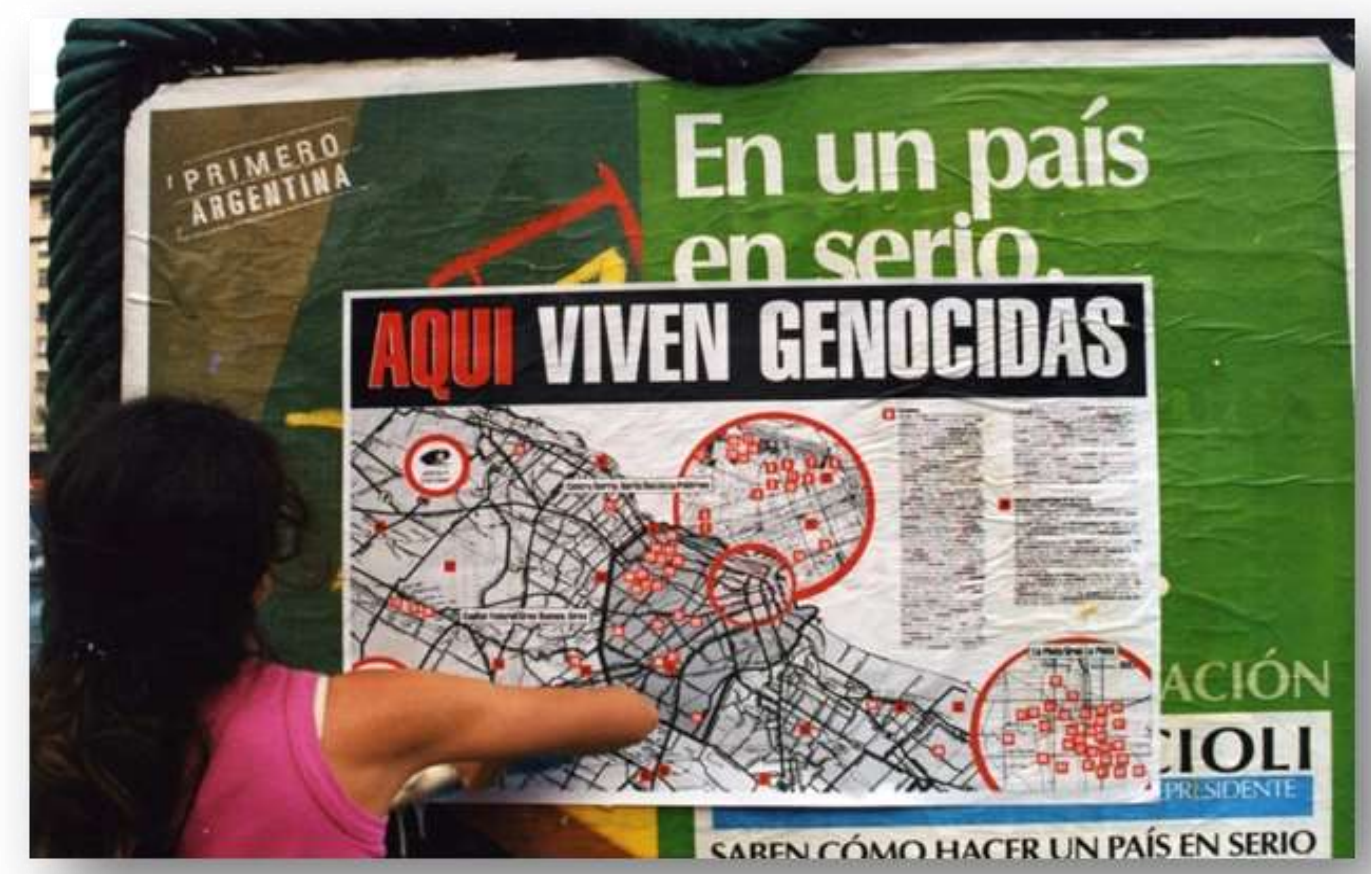

Figura 15. Fonte: Divulgação.

\footnotetext{
78 Necessário ressaltar que nenhum dos grupos, Arte Callejero (GAC) e Etcétera (ETC), recebem apoio financeiro e nem integram partidos políticos. As ações são financiadas pelos próprios integrantes.
} 
Na sua formação atual, o grupo de Arte Callejero $^{79}$ é composto majoritariamente por mulheres. Os escraches são obras de denúncia e a relação com o espaço marca um mapa da cidade onde a violência velada opera na impunidade de absolvição dos militares. O grupo Etcétera ${ }^{80}$ nasce em 1998 e, no ano de 2001, realiza três ações em decorrência da urgência das ações culturais em parcerias com os movimentos de protestos. Sua escolha por indícios surrealistas atua diretamente no ativismo político, no contra fluxo da economia neoliberal. A primeira ação Las Bodas de Plata consistia em denotar o Golpe de Estado (1976), por meio de vestimentas de alto padrão, no intuito de construir um casamento (Bodas de Prata) entre o

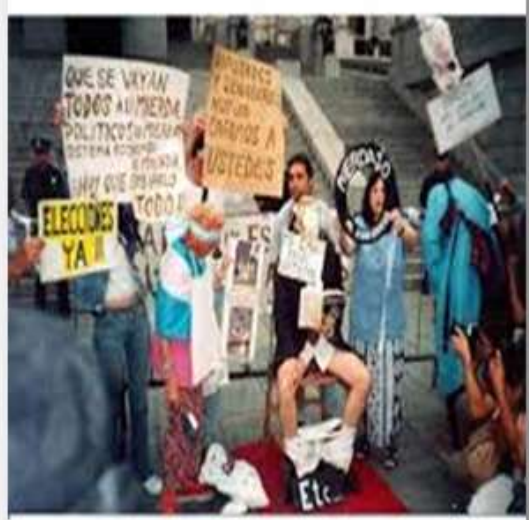

Figura 16. Fonte: Divulgação. governo militar e sua nova noiva, o então presidente Fernando de La Rúa, tendo como padrinhos os ex-presidentes e ministros (Menem, Alfosin e Cavallo). A composição visual cênica se deu com a representação de um bolo gigante feito com dinamites, convidando os envolvidos a se entregarem aos manifestantes. Em 2002,

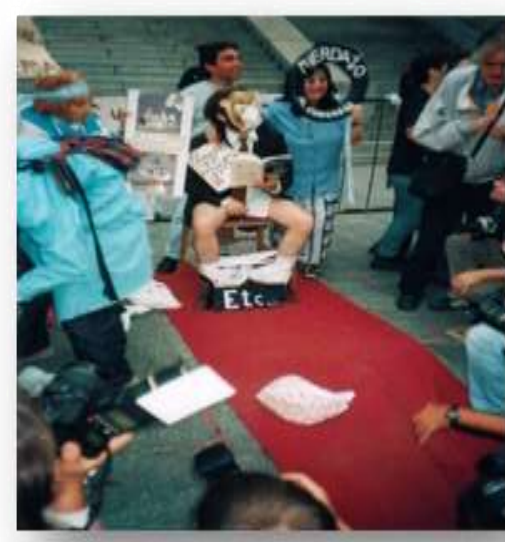

Figura 17. Fonte: Divulgação. a ação Mierdazo lança convite à população a guardar e jogar seus excrementos ou de outras pessoas nas portas do Congresso Nacional, durante a reunião de ajuste orçamentário anual. Os integrantes do grupo compuseram uma ação escatológica que remetia à política suja. Um dos integrantes, usando máscara de ovelha, defecou em um tapete vermelho na frente do Congresso. Ironicamente a ação se estendeu para outras localidades e, em seus desdobramentos, a população depositava, por meio de caminhões, dejetos nas portas de bancos que inflacionavam suas rendas. O diagnóstico de insatisfação social transformou a ação mais participativa ao tornar a população coautora das ações oriundas do grupo. Ao

\footnotetext{
79 As artistas que integram o grupo Arte Callejero (GAC), atualmente, são: Lorena Bossi, Carolina Golder, Mariana Corral, Vanesa Bossi e Fernanda Carrizo. Fonte: https://grupodeartecallejero.wordpress.com/quienessomos-2/. Acesso em: 20/07/2018, às 00h49.

${ }^{80}$ Fonte: https://grupoetcetera.wordpress.co. Acesso em: 20/07/2018, às 01h42.
} 
conseguirem adesão populacional nessas ações, os grupos de protestos, população e ações táticas, no país, demonstraram a eficácia das reivindicações do povo argentino.

Nessas parcerias, surgem novas diretrizes sociais, em que a participação do H.I.J.O.S, Madres e Abuelas caminha para novas buscas no que concerne às mulheres. $\mathrm{O}$ apoio e a parceria desmembram um forte avanço referente às políticas públicas atreladas ao corpo da mulher e, numa jogada virtuosa (descriminalização do aborto) do atual presidente, coloca o país em um debate que pode levar a Argentina a um avanço próximo aos países europeus. Sobre isso, os H.I.J.O.S se posicionam:

Buenos Aires, 11 de junio de 2018

Sres./Sras. Diputados/as de la Nación Argentina

$S / D$

De mi mayor consideración,

Las organizaciones derechos humanos y de mujeres abajo firmantes nos dirigimos a Ud. a efectos de reclamar el apoyo al proyecto que se debatirá el próximo 13 de junio en el Congreso de la Nación.

En primer lugar, no podemos más que celebrar a quienes están acompañando con su voto el proyecto de ley sobre interrupción voluntaria del embarazo puesto que implica reparar una deuda de la democracia con las mujeres y personas con capacidad de gestar y, a su vez, honra los compromisos que el país asumió en materia de derechos humanos y que son parte de nuestra Constitución.

El debate llevado a cabo por la Cámara de Diputados mediante un proceso de audiencias públicas participativas y plurales, ha dado como resultado un dictamen que será puesto a consideración en el recinto el próximo miércoles. Este dictamen ha sido el resultado del diálogo e intercambio de información para lograr una transformación sustancial en nuestro régimen legal que garantiza la vida, la salud, la dignidad, la intimidad y la vida sin violencia de todas las mujeres y personas con capacidad de gestar.

En estos dos meses, la sociedad ha manifestado su apoyo a la despenalización y legalización del aborto a lo largo todo el país a través de los distintos ámbitos: la academia, los medios de comunicación, sindicatos, organizaciones sociales, legislaturas provinciales y municipales, referentes de la cultura y el espectáculo. En especial, los y las adolescentes han sido actores relevantes en estos meses.

Las encuestas reflejan que más de la mitad de la población está a favor de la despenalización del aborto.

Argentina está siendo observada por toda la comunidad internacional a la espera de que adecúe su legislación a los estándares internacionales de derechos humanos. El Comité para la Eliminación de la Discriminación contra la Mujer(2016), el Comité de Derechos Humanos (2016) así como el Comité de los Derechos del Niño(2018), entre otros, han remarcado la necesidad de que Argentina garantice el acceso a la interrupción voluntaria del embarazo.

Votar la despenalización del aborto es adecuar el marco jurídico argentino a los compromisos internacionales asumidos por el país tras la ratificación de los instrumentos de derechos humanos. Es garantizar en la ley lo que ya es un derecho de las mujeres. 
No existe en el derecho internacional ni constitucional justificación alguna para amenazar con la cárcel a quien interrumpa un embarazo no deseado, ni para obligar a una mujer o niña a seguir adelante con dicho embarazo. La criminalización no impedirá que las mujeres en su intimidad sigan eligiendo interrumpir sus embarazos no deseados. Despenalizar el aborto en la Argentina terminará con un círculo en el que las mujeres solo tienen como opción la cárcel, la clandestinidad o la muerte.

Este Congreso no está votando aborto sí o aborto no, está votando si las mujeres deben someterse a procesos inseguros y riesgosos para su vida y salud a la hora de hacerlo. Las organizaciones firmantes solicitamos no dar la espalda a las mujeres y a acompañar con su voto el aborto legal. Es momento de hacer historia ${ }^{81}$.

\subsection{Corpos ilegais}

Nosso encontro mais recente com os movimentos reivindicatórios dos direitos das mulheres ocorreu no dia 28 de junho de 2018, por volta das 19 horas e 50 minutos $^{82}$. Um barulho estrondoso ecoava na Avenida de Mayo em Buenos Aires/Argentina, o que gerou dúvidas sobre o que poderiam ser as algazarras e o som que ecoava entre os edifícios e arranha-céus imponentes, que direcionam, em linha reta, as pessoas da Casa Rosada ao Congresso Nacional Argentino. Numa trajetória pendular de poder entre as duas instituições do país. Pairava a dúvida do que se tratava. Caminhando da Casa Rosada até o Congresso, um grupo, ainda não identificado, modificou a avenida naquele momento. $\mathrm{O}$ encontro com esse grupo, ainda sem nenhuma faixa ou elementos que os identificasse, revelou, em meio a muitos gritos, a voz de uma mulher trans aos motoristas que se recusavam a esperar a multidão passar. Ela gritava: - Senhor, senhora, nós somos diferentes. Em suas mãos, um panfleto atribuído aos direitos à resignação sexual e respeito. Um motorista

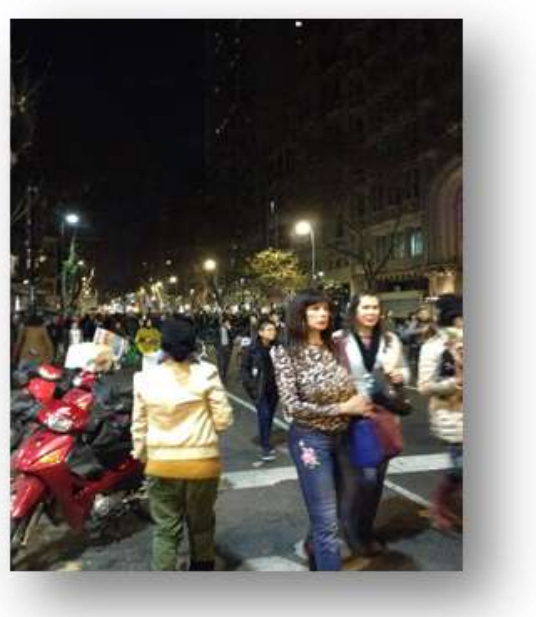

Figura 16. Foto: Flaviana Benjamin. ameaçou jogar o veículo em cima dela. Os outros motoristas que se viram obrigados a esperar xingavam e hostilizam as pessoas que pediam calma para a multidão passar em segurança.

\footnotetext{
${ }^{81}$ Disponível em: http://www.hijos-capital.org.ar/2018/06/11/por-el-aborto-legal-seguro-y-gratuito/. Acesso em: 20/07/2018, às 02h43.

${ }^{82}$ Esta narrativa faz parte da pesquisa de campo, realizada pela pesquisadora, em Buenos Aires/Argentina, em junho de 2018.
} 
Outro panfleto, Marcha Nacional 28 de Junio - 17hs Basta de Travesticidios, Basta de Transfemicidios, trazia imagens de várias mulheres trans. Logo, outros grupos se aproximavam, portando bandeiras LGBTQI+. As mulheres que pediam a legalização do aborto eram as que arrastavam maior número de adeptas. Desta forma, ficou claro que se tratava do ato referente à descriminalização do aborto, que teve sua primeira sessão de votação na Câmara dos Deputados em 14/06/2018, quando o grupo favorável foi vitorioso. Nesta trajetória, assim como as Madres, Abuelas e H.I.J.O.S, muitos movimentos de protesto acolheram a luta pela descriminalização do aborto na Argentina. No Brasil, as mulheres trans têm participado cada vez mais da caminhada no dia 8 de março e, em Buenos Aires, a adesão dessas representantes deu força para discutir questões além do determinismo biológico, em algo que irá beneficiar a todos, como saúde pública. Além disso, a luta pela liberdade dos corpos acomete tanto mulheres cis, quanto trans e homens trans. Os homens trans também abortam com indicativos de que seus corpos também sofrem opressão. Neste aspecto, a participação e apoio de todos gera debate e avanços sociais, não apenas aos grupos de luta, mas no diálogo da educação sexual e reprodutiva, em um debate de responsabilidade nacional.

A tradição dos protestos, depois do período da ditadura sanguinária, trouxe para a Argentina a prática habitual de manifestar-se. Nos espaços de protesto, a rua se tornou o principal local de formação política do povo portenho e, neste contexto, a cidade de Buenos Aires parecia adornada para receber as discussões frente aos direitos reprodutivos das mulheres. Cartazes, pichações, intervenções alteravam a arquitetura colonial da cidade com interferências da opinião popular. Um radicalismo oriundo dos grupos históricos nos movimentos de protestos, que em sua trajetória trouxe diversas formas de expressão simbólica para os fatos ocorridos no país.

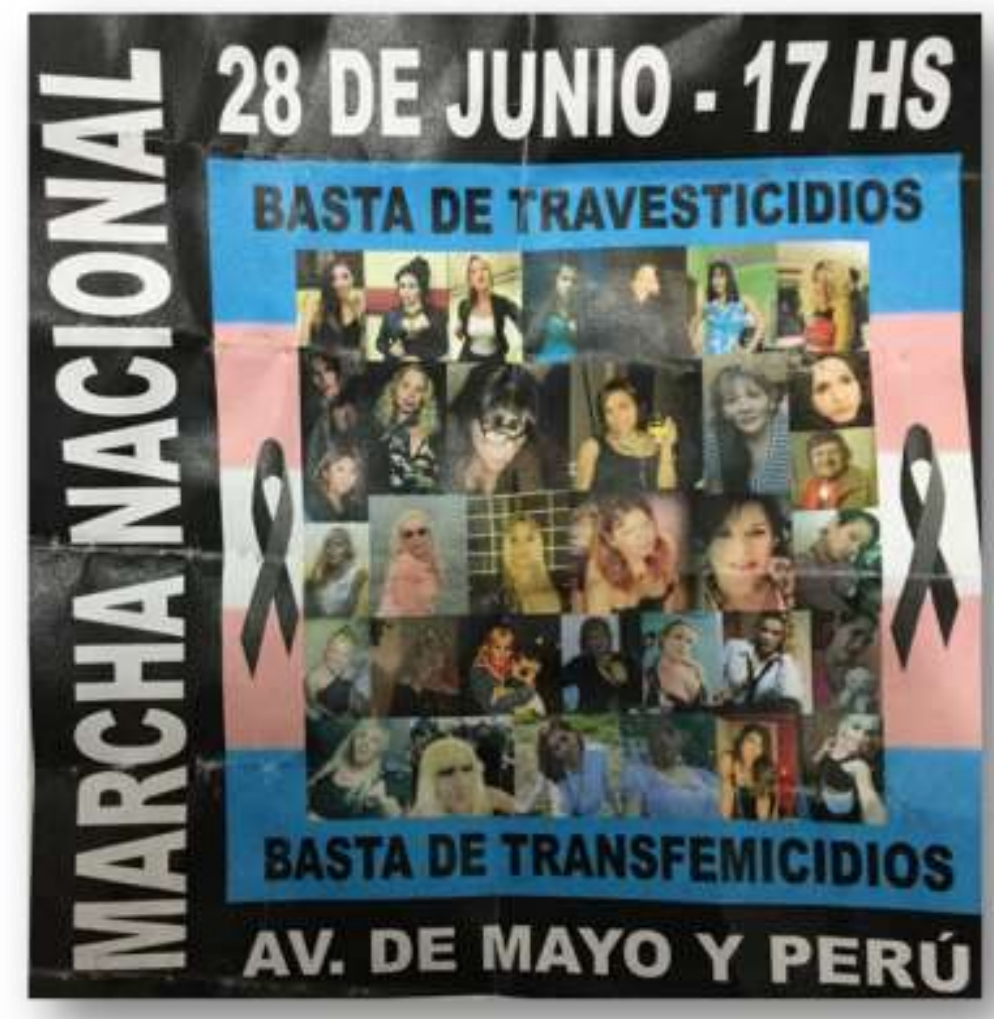

Figura 17. Foto: Divulgação. 
Diferente da tríade de presidentas (Argentina, Brasil e Chile), que não tiveram coragem de enfrentar os tabus e discussão acerca do aborto, a medida foi impulsionada pelo atual presidente Mauricio Macri, que, assim como seus antecessores, encontra-se em baixa populacional, depois de aprovar a reforma da previdência, contrair novo empréstimo junto ao FMI, ter a inflação e o dólar disparados - ou seja, a ruína das medidas socioeconômicas segue países da América Latina. Nesta derrocada, lança um debate que exige muito fôlego para sanar outras deficiências governamentais no país. Mesmo nós, latinos com a cultura voltada (construída) para o corpo, festas e ritmos calientes, somos carentes de debates em torno de políticas relacionadas à saúde pública e, em consequência, os tabus ressurgem com força retrógrada. A Lei que foi engavetada nos anos de 2003 a 2015 por Nestor e Cristina Kirchner, que eram contrários à descriminalização do aborto, impediram qualquer possibilidade de trâmites no Congresso naquela época. Impulsionado pela tentativa de aumentar sua popularidade, junto aos grupos de esquerda e centro-esquerda, Macri, após receber informações de que a possibilidade de vitória seria baixa, lança mão deste artifício que modificou e alavancou ainda mais os movimentos feministas a lutarem por esta medida pública. Se o presidente e seus assessores não contavam com a força que isso poderia provocar na organização das mulheres, em relação a seus direitos, não há como saber. Mas, nesta perspectiva, a Argentina se abre à grande onda, pronta para alastrar por toda América Latina, acerca dos avanços que não cessarão facilmente.

\subsection{Intimidade nas ruas: Dicotomias e tensões}

Neste encontro com o movimento de protesto em prol das políticas públicas relacionadas ao aborto, a divisão entre adeptos e não adeptos ocupava as ruas argentinas em pequenos grupos de debates em torno desta questão. A divisão entre sim e não estava disposta por toda a cidade. Pichações contra a descriminalização permitia mensurar que a população estava dividida e, se não, mais adepta à negação deste direito. Um homem de aparentemente 30 anos, no máximo, apresentou-se como gay, interpelando algumas mulheres e a mim, curioso, por entender porque as mulheres estavam apoiando a causa. Sua negação taxativa se dava porque, se não fosse uma mulher, sua mãe, ele certamente não estaria ali. As mulheres o respondiam dizendo que não se tratava disso, mas de legalidade ou clandestinidade, e que a opinião contrária só contribuiria para que mulheres, sem condição de arcar com os custos, 
continuassem sofrendo e morrendo. Além de receberem punição moral, pois muitos agentes de saúde se negam a medicar mulheres que abortam quando estas recorrem a um Hospital. Ele, dentre muitos, segundo o depoimento das mulheres, durante o protesto, revelava as influências religiosas da culpa em relação à vida e à morte.

Se, para alguns, as mulheres têm a incumbência de gerar a vida, qual seria a função do outro? Esse determinismo biológico taxativo, usado por grupos religiosos como artificio de controle, não revela as estratégias desses grupos no Congresso Argentino.

Assim como no caso de Macri, as estratégias no campo da saúde pública em detrimento das pautas feministas também foram usadas em campanhas eleitorais em toda a América Latina. No Brasil, um caso emblemático aconteceu na disputa presidencial de 1989 entre Fernando Collor de Melo (Partido da Reconstrução Nacional - PRN) e Luis Inácio Lula da Silva (Partido dos Trabalhadores - PT).

Com crescimento nas intenções de voto, medidas pelas pesquisas eleitorais tendendo ao petista, Collor lança, como estratégia aliada à Rede Globo, canal de televisão com maior audiência no Brasil, em horário nobre, um depoimento da ex-namorada de Lula, no ano de 1974, pedindo que eles (Lula e sua namorada) realizassem um aborto (JORDÃO e CABRINI, 2017, p. 302). A narrativa íntima trazida pelo depoimento pessoal deu foro à deslegitimação de um debate que, inserido de maneira desmoralizante durante a disputa por votos, retardou a discussão do direito das políticas do corpo das mulheres. Esta atitude eleitoreira produziu retrocessos conservadores que não levaram em conta a seriedade e a necessidade da discussão sobre a descriminalização do aborto para a população de mulheres brasileiras, embora esta não tenha sido pauta

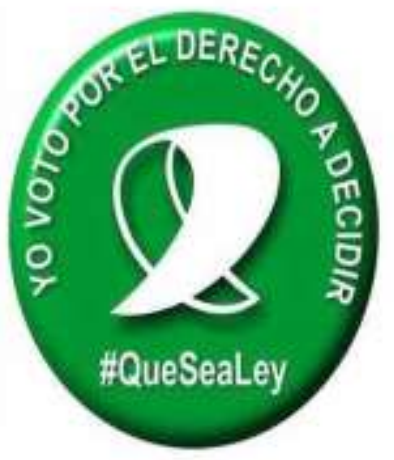
dos partidos envolvidos.

Figura 18. Foto: Divulgação.

A temática do aborto não aparece na radicalidade da performance arte, nem tampouco nas dramaturgias teatrais que se encontram longe das polêmicas sobre o assunto, deixando campo aberto para discussão aos movimentos de protesto, à rua e às feministas, neste páreo difícil de legitimar, mesmos sendo pautas necessárias à saúde das mulheres frente a estruturas conservadoras. A performance arte e o teatro tendem a distanciar-se desta premissa e optam por tratar mais o campo da violência doméstica, que, muitas vezes, se dá porque as mulheres 
temem denunciar ou sair de casa, uma vez que podem receber punições e, com isso, deixar de ver seus filhos. Não somente a denúncia opera nesta chave, mas o reflexo de uma sociedade violenta contra o corpo da mulher e poucas políticas públicas que possam ampará-las após deixarem seus lares ou parceiros. Desta maneira, os debates sobre aborto poderiam tangenciar violências que acontecem no ambiente doméstico. A punitiva que gira em torno da formação familiar muitas vezes tem os filhos como elemento direto no silenciamento de algumas mulheres. Se a arte está mais voltada para o debate da violência doméstica, os movimentos de protestos têm ocupado e criado espaços de discussão acerca de assuntos de rechaço social. As estratégias escolhidas criam texturas estéticas dentro do campo das lutas sociais. Assim, como em meu corpo é um campo de batalha ${ }^{83}$, as mulheres atuam cada vez criando estéticas e artifícios para ocupar espaços estigmatizados e com alto teor de conservadorismo. Rompem e burlam a Lei que pouco favorece suas necessidades.

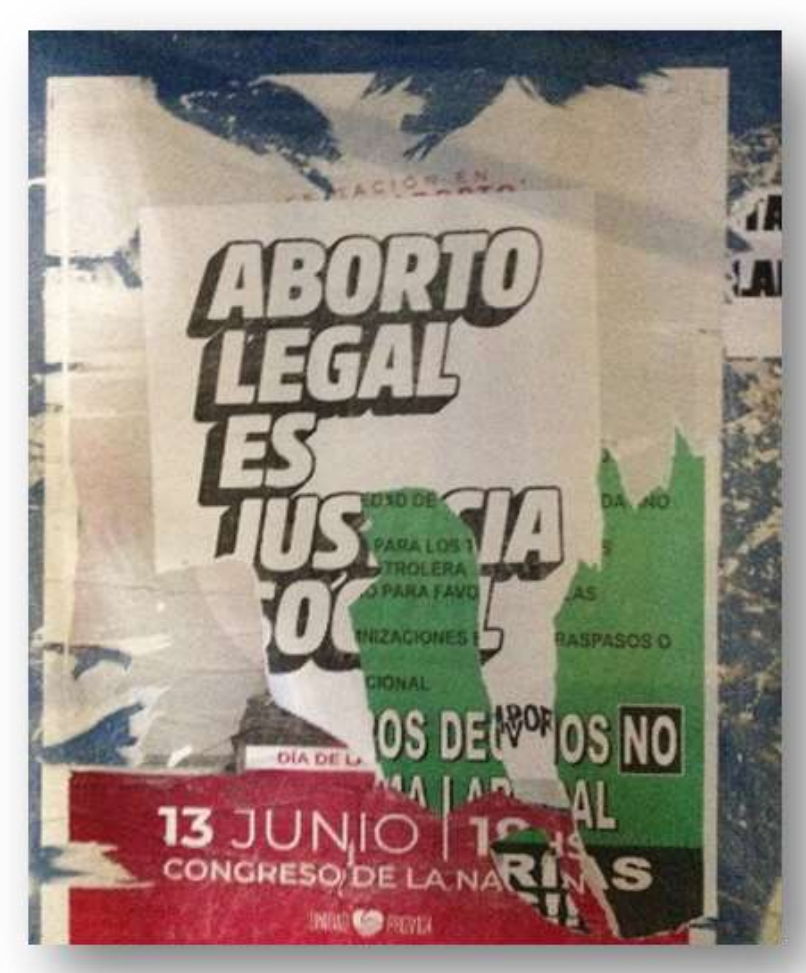

Figura 19. Foto: Flaviana Benjamin.

\footnotetext{
${ }^{83}$ No original: Your body is a battleground. Obra de Barbara Kruger (1989). Na tradução literal: Seu corpo é um campo de batalha.
} 


\subsection{Simbolismo urbano}

Nas ruas da cidade de Buenos Aires, dias antes do encontro inesperado com o protesto de descriminalização do aborto, fomos acolhidos pela cidade hermana repleta de cartazes que fortemente afirmavam a liberdade do corpo da mulher dada por ela mesma. A possibilidade de escolha e a responsabilidade social de reconhecer que cabe à mulher decidir sobre seu corpo e saúde era vista em cartazes e grafites em espaços públicos. A rua se configurava em um dualismo de sim e não, em uma luta indireta de forças opostas. As mulheres contra a descriminalização do aborto eram/são minoria. E, segundo depoimento das integrantes dos movimentos pró-aborto, as mulheres contra a descriminalização são maioria, mas não apresentam histórico e

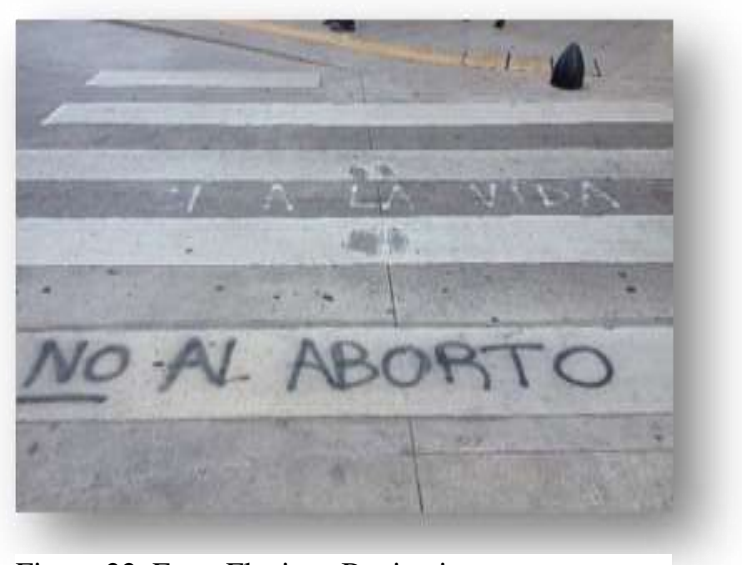

Figura 22. Foto: Flaviana Benjamin.

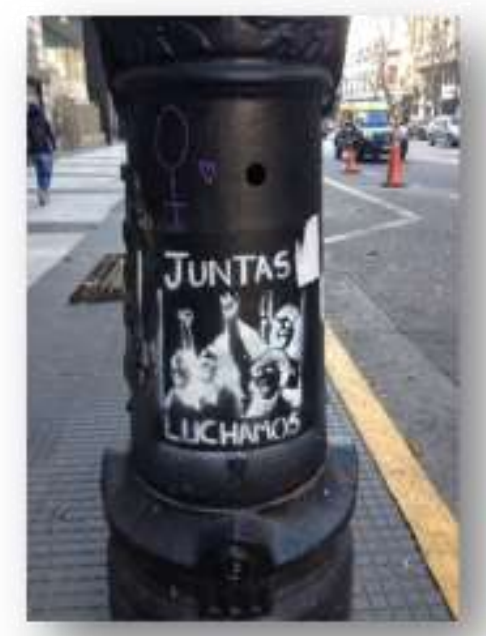

Figura 23. Foto: Flaviana Benjamin. estratégias de luta como mantenedoras dessa prerrogativa conservadora. Muitas destas se diziam contra, porque estavam apegadas às consequências punitivas da religião e o peso do determinismo biológico, que coloca como principal papel (destino) das mulheres a reprodução. Com o slogan de sermos as responsáveis pela humanidade, o determinismo biológico toma força e avança com outros retrocessos, em consequência do avanço do conservadorismo, o ódio às políticas do corpo e a intolerância social a grupos não hegemônicos. 
Assim como em campanhas eleitorais partidárias, o disfarce conservador rende, aos envolvidos, melhor aceitação ao meio social. Pessoas que se colocam no campo dos pensamentos atrelados à esquerda, como a legalização do aborto, tendem a ser vistas como imorais e desviantes. Este retrocesso interfere nos avanços por direitos a grupos não hegemônicos e que são vinculados a guetos e intimidados pela massa hegemônica, seja através do rechaço ou por via mais comum:

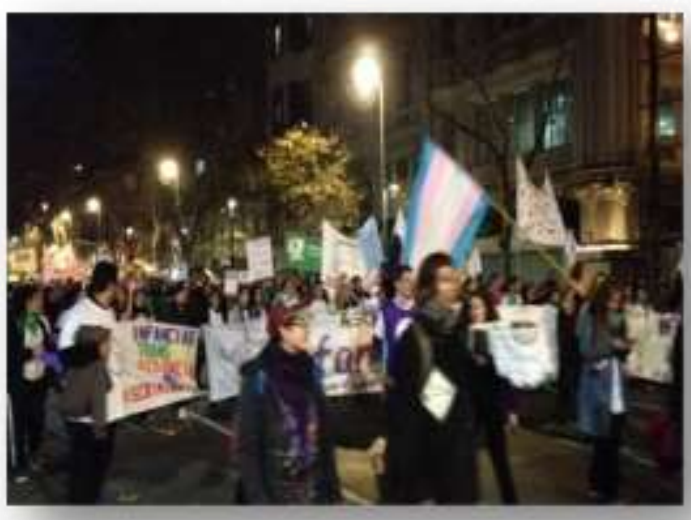

Figura 24. Foto: Flaviana Benjamin. violência e morte. Neste sentido, ao afirmarem a rua, o espaço público como lugar da disputa e grito pelos direitos, as mulheres se posicionam contra o seguimento conservador, higienista, moralista, normativo, sexista, hegemônico, que insiste em apagar as políticas da diferença. Assim, os implicados, como os grupos LGBTQIA+, trans (homens e mulheres) e muitos outros, podem compreender seus corpos a partir da participação das lutas das diferenças. Pertencentes ou não a grupos de protestos, passam a somar na luta por esses avanços e, no contexto portenho, parecem estar mais coesos do que no Brasil. Um diagnóstico possível, sobre outros personagens sociais parecerem mais coesos na Argentina, decorre do fato de que as pautas em comum tendem a contemplar reivindicações próximas; já no Brasil, as diferenças incluem outros grupos que tendem a sofrer outras ou mais violências.

Neste aspecto, citamos exemplo das mulheres negras, indígenas, mulheres trans e homens trans. Além disso, o Brasil é o $5^{\circ}$ pais que mais mata mulheres ${ }^{84}$ no mundo e o $1^{\circ}$ na morte de pessoas trans ${ }^{85}$. Ao problematizarem a questão do aborto, as argentinas logo direcionavam sua fala à experiencia pessoal, seja por experiência íntima, familiar ou referência a suas amigas. Em cada espaço, o assunto tomava grande proporção. Eram retratados em cafés, restaurantes, filas de supermercado, metrôs, ou seja, por todos os lados ouvia-se muito a respeito da tramitação da Lei. Uma companheira disse ter sido mãe aos 16 anos de idade: feliz e orgulhosa da filha, expõe uma foto da criança brincando. Conta-nos que teve apoio familiar durante a gravidez e nunca quis abortar, e posiciona-se a favor do aborto,

84 Disponível em: http://www.unifesp.br/reitoria/dci/entreteses/item/2589-brasil-e-o-5-pais-que-mais-matamulheres . Acesso em: 25/07/2018, às 00h28.

${ }^{85}$ Disponível em: https://www12.senado.leg.br/radio/1/noticia/brasil-e-o-pais-que-mais-mata-homossexuais-nomundo. Acesso em: 25/07/2018, às 00h28. 
já que muitas mulheres podem não ter tido a mesma sorte que ela. O pai da criança jamais a procurou depois que ela o notificou a respeito da gravidez. E, desde então, ela segue trabalhando e estudando em Córdoba, cidade que reside para criar a filha.

Os relatos pessoais extrapolam elementos concretos e ampliam o seguimento enrijecido do ambiente social, somando-se em mais um objeto de desejo da arte contemporânea. A autobiografia se firma não apenas no como dizer, mas no dizer político. As expressões de singularidade e subjetividade revelam fissuras da fratura social, compondo formas de escuta e revisando a história não apenas como fragmentos das reminiscências, mas como deslocamento de pontos de vista, apoiando-se numa experiência mais que necessária na América Latina, ou melhor, em todo o Cone Sul, que, desde seu princípio, teve sua história narrada e documentada por outros. Desta forma, a autobiografia revela a narrativa da experiência dolorosa de corpos não narráveis. A dor trouxe artifício de reivindicação de um outro lugar na sociedade.

\subsection{Ni una menos}

Os cartazes referentes à morte de Marielle Franco ${ }^{86}$ também estavam dispostos na cidade argentina como apoio às mulheres vitimadas pela violência que ocorre diariamente na América Latina. Unidos pela língua (espanhol), Argentina, Chile e Uruguai, em 2015, se lançam, por meio das mulheres, contra as atrocidades que levaram à morte Chiara Páez, de 14 anos. Grávida, foi morta e enterrada pelo namorado na província de Santa Fé, na Argentina. Depois de uma onda de mulheres desaparecidas serem encontradas mortas, um grupo de mulheres se reuniu em Buenos Aires, na praça Boris Spivacow, dando força motriz à visibilidade das mortes de mulheres no país. Os grupos feministas colheram evidências que reforçaram o apoio popular. A campanha com o uso da expressão ni una menos se deu depois da morte de Susana Chavéz, ativista dos direitos das mulheres, morta em 2011 no México. Outras mulheres, jornalistas, artistas e integrantes de grupos feministas transformaram esta frase na força e mobilização das mulheres. O motim, iniciado depois das mortes de mulheres que pagaram com a vida, gerou uma mobilização nacional, somando-se não apenas aos grupos feministas, mas a um levante que uniu os três países.

\footnotetext{
${ }^{86}$ Marielle Franco (1979-2018) foi vereadora pelo Partido Socialismo e Liberdade - PSOL, socióloga, feminista, negra, lésbica, mãe, atuava no direito à cidade e direito à favela. Foi assassinada a tiros em 14 de março de 2018, depois de ter denunciado atrocidades relacionadas à intervenção militar no Rio de Janeiro. Até hoje não há respostas sobre sua morte.
} 
O apoio de outros segmentos da sociedade, como jogadores de futebol, artistas e figuras públicas, garantiu adesão ao combate à violência de gênero. Atrizes de televisão também aderiram à campanha e, em protesto, fizeram uso do cacerolazo em frente ao Congresso Nacional, em apoio à causa.

Nesta mobilização, o Uruguai se mostra pioneiro entre os países da América do Sul. Em 2012, legalizou o aborto, tornando-se o terceiro, da América Latina, liderado por Cuba em 1965 e Guiana em 1995, no que diz respeito a esta Lei. Outros avanços, como regulamentação da prostituição (2002), adoção de crianças por casais homoafetivos (2009) e união civil de pessoas do mesmo sexo biológico (2007), colocam o Uruguai em posição de destaque em relação a processos emancipatórios de direito.

Não apenas os cartazes e arranjos estéticos direcionavam a reflexão em torno da descriminalização do aborto em Buenos Aires: meninas usavam maquiagens emblemáticas na cor verde e carregavam seus lenços verdes em formato triangular, para marcar suas opiniões. Nos finais de semana, as escolas, mesmo de seguimento religioso, abriram suas portas para discutir, entre jovens e adolescentes, as pautas referentes ao aborto.

A religião, que também exerce grande influência no Brasil, não teve força para evitar $a$ onda verde, nome dado ao efeito da descriminalização na Argentina, que cresce ao aproximarse da data do veredicto, marcado para o dia 08 de agosto de 2018. Nenhuma das mulheres que conversamos soube dizer se há possibilidade dessa lei ser realmente aprovada. O clima de indecisão desde o início do trâmite também cresce na medida em que alguns senadores mudam de posição. Caso aprovado, as mulheres passam a ter seguridade abortiva pela rede pública e muitas não teriam que conviver com a punitiva de 4 anos de prisão imposta às mulheres que abortam. Esta ação penal ainda vigora e também é realidade no Brasil, ou seja, além de não existir direito ao corpo, ainda conta com regime punitivo, severo e criminal. 


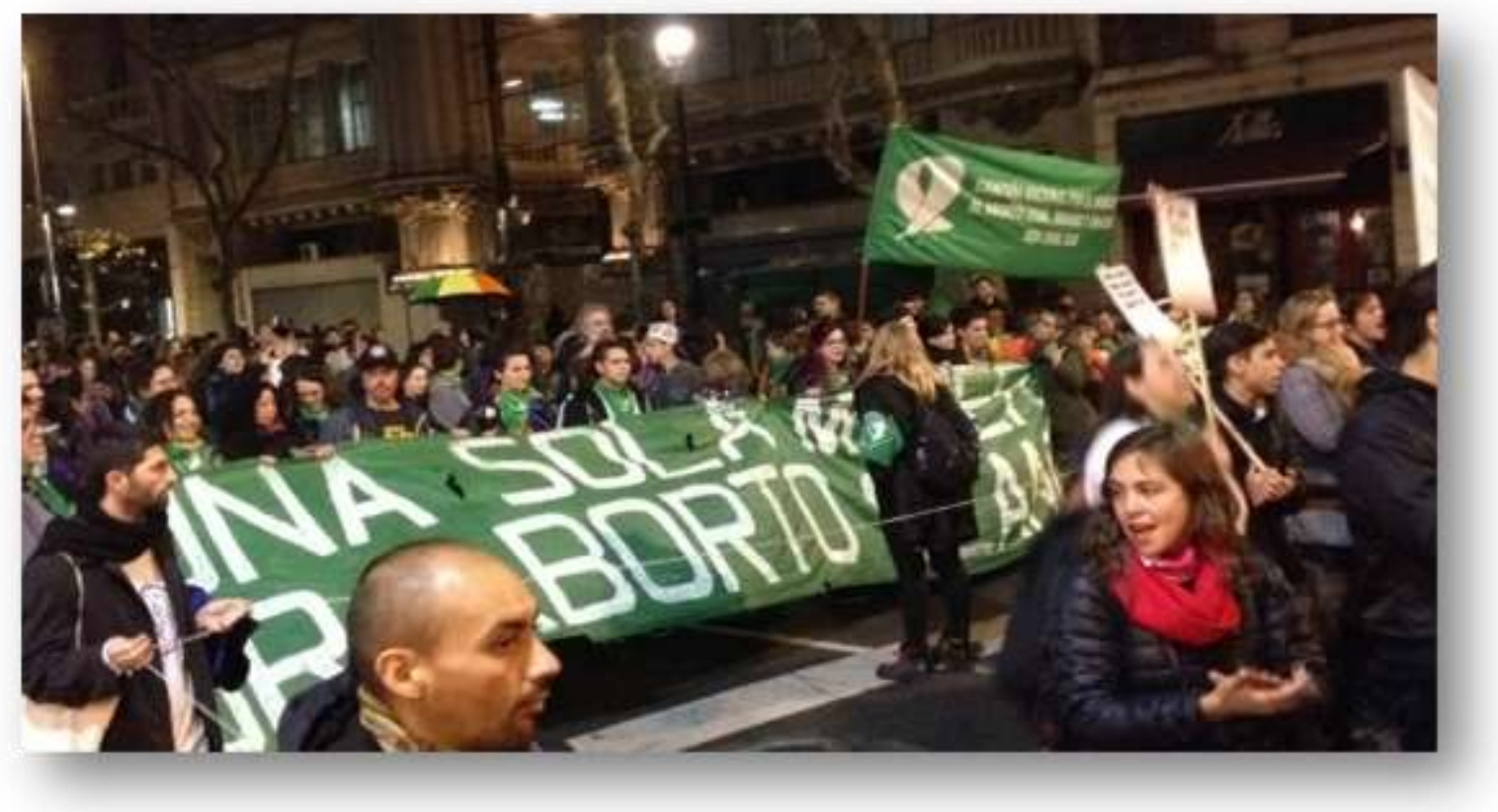

Figura 25. Foto: Flaviana Benjamin.

Em oposição, algumas pessoas aderiram ao lenço azul claro como símbolo contrário a descriminalização. A escolha pelas cores reforça a falsa ideia de patriotismo desses grupos, quando atrelam as cores da bandeira do país ao que eles entendem por valorização da vida.

Qualquer decisão tomada no dia 08 de agosto de 2018 na Argentina ${ }^{87}$ certamente não mudará nosso desejo de que esta realidade seja para todas em princípios claros de emancipação de direitos. Nosso posicionamento independe do aval dado pelos senadores. A onda verde e os movimentos de protestos se prestaram a princípios-chave: levantar o debate e a informação acerca da política populacional, apresentando, desta forma, maneira objetiva de fazer política, firmando a manutenção da população sobre temas que são base na construção de um mundo pautado em equidade.

Nesta trajetória de encontrar estratégias do lar para a rua, por meio de necessidades urgentes e básicas, diagnosticamos novas formas de manifestar a autobiografia. Concordando com o espaço autobiográfico apresentado por Arfuch (2010), em que a expressão livre faz emergir mais dicotomias autobiográficas e autoficcionais, na medida em que as estruturas e relações dão condições de inserir e diagnosticar as diversas armadilhas nesse jogral do fazerse ver. Entendendo que cada escolha e atribuições acerca do eu percorre sua própria combinação em prol de novas diretrizes no campo das diferenças.

\footnotetext{
${ }^{87}$ Optamos por não modificar a escrita depois da derrota da descriminalização do aborto na Argentina. Com 2 abstenções, 31 votos a favor e 38 contra, a Lei de interrupção até a $14^{\circ}$ semana de gestação foi vetada pelo Senado.
} 
O mais próximo que chegamos das discussões referentes ao aborto no Brasil foi em 2012, quando o Supremo Tribunal Regional (STF) defendeu que não seria mais crime aborto de fetos anencéfalos pela Arguição de Descumprimento de Preceito Fundamental (ADPF) (BLAY, 2017, p. 335). Recentemente esta medida passou a ser pauta novamente, mas, embora seja um avanço, ainda estamos longe de qualquer possibilidade de descriminalizar o aborto no cenário político atual. Como o investimento ${ }^{88}$ e coalisões nas campanhas políticas são oriundos de bases religiosas e ruralistas, ficamos presos ao conservadorismo. Nesta urdidura, as mulheres de baixa renda - em sua maioria, negras - são as que mais morrem devido a métodos abortivos clandestinos e sem auxílio médico legal. Um alarmante que denota: a morte de mulheres durante o aborto ${ }^{89}$, no Brasil, tem cor.

\subsection{Sobre nós}

O processo relacionado à memória do trauma corrobora para a "compreensão relacional e não individualista da subjetividade" (TAYLOR, 2013, p.265). Assim, as lembranças atravessadas pela dor se tornaram dispositivos de criação muito presentes na arte contemporânea. Localizados nas mais variadas linguagens, estes dispositivos trazem consigo a conexão com diversos meios de produção, para justapor obras em processos de experimentação.

Nosso $^{90}$ primeiro experimento é a partir do anúncio de uma doença que acometeu a representante feminina da família: minha mãe. Isto deu vazão para uma série de desdobramentos artísticos em linguagens variadas, que tratavam do mesmo mote. O câncer uterino da matriarca (idosa) fez pensar as estruturas sociais das funções do corpo feminino e todas as amarras e agenciadores sociais que atuam nele. Se o corpo não é da mulher, como demonstram Leis que tentam legitimar escolhas, como a função reprodutiva, então conclui-se que nada temos de nosso.

A origem desta análise se deu no Hospital Pérola Byington, localizado na cidade de São Paulo, uma referência em saúde da mulher. Lá, encontram-se casos oriundos de diversos locais do Brasil, inclusive mulheres vítimas de violência doméstica. A permanência de homens no local é restrita, quase não há, mas a diversidade de mulheres é muito grande. São

\footnotetext{
${ }^{88}$ Há a campanha de financiamento público e o fim do patrocínio de empresas nas eleições atuais.

${ }^{89}$ Cf. FREIRE, Nilcéa. Aborto seguro: um direito das mulheres?. Cienc. Cult., São Paulo , v. 64, n. 2, p. 31-32, June 2012.

${ }^{90}$ Neste fragmento, digo “nosso”, incluindo Glória, minha mãe, como coautora neste processo.
} 
atendidas presidiárias, adolescentes, portadoras de HIV; em sua maioria, mulheres pobres. Também existem muitos programas relacionados à saúde e beleza. Em alguns casos, as mulheres recebem maquiagem, perucas e lenços, para usarem durante o tratamento de quimioterapia. Há programa de desfile de moda, promovido em parceria com instituições privadas, com o intuito de devolver a autoestima dessas mulheres. Parece que o retorno social e familiar se dá com retorno da beleza, já que um dos tipos de quimioterapia faz cair os pelos do corpo e, outro, pode causar deformação física ou pequenas queimaduras, como resultado do processo de radioterapia. Além deste Hospital, frequentamos também o Hospital Beneficência Portuguesa, no qual não havia divisão de gênero e o espaço de atendimento acolhia a todos. Neste percurso, ouvimos muitas mulheres que também em tratamento contavam suas angústias. O que mais aparecia como queixa não era o medo da morte, por conta do câncer, mas a perda dos cabelos.

Neste aspecto, diagnosticamos o peso das estruturas sociais e agenciadores do corpo que, mesmo em busca de saúde, fazem com que as mulheres pensem nas suas imagens através do imaginário social ${ }^{91}$. Medo de não ter mais as referências do imaginário de feminilidade (seios, cabelos, estética genital), pois, em alguns casos, por exemplo, a braquiterapia deixa aparência escura na região da vagina e do ânus. Algumas mulheres se esqueciam do processo agressivo que as acometia e reportavam a força em manter a imagem social de produção de saúde.

\subsection{Corpo}

A pergunta - De quem é esse corpo? -, lançada pela artista e pesquisadora Lúcia Romano (2009) em sua tese de doutoramento ${ }^{92}$, permite diagnosticar o quão longe a mulher está de seu corpo. Este paradigma é sintoma da batalha de legalização necessária à promoção da saúde da mulher. A descriminalização do aborto é exemplar do quanto estamos distantes de decidir por nós mesmas. A negativa de médicos a pedidos de retirada de útero a mulheres com menos de 30 anos e a reinserção estética do corpo ao padrão binário decorrentes da retirada

\footnotetext{
${ }^{91}$ CASTORIADIS, C. A Instituição Imaginária da Sociedade. Trad. Guy Reynaud. Rio de Janeiro: Paz e Terra, 1991.

${ }^{92}$ Cf. ROMANO, Lucia Regina Vieira. De quem é esse corpo? - a performatividade do feminino no teatro contemporâneo. 2009. Tese (Doutorado em Teoria e Prática do teatro) - Escola de Comunicação e Artes, São Paulo, 2009. Acesso em: 03/08/2018.
} 
mamária devido ao tratamento de câncer são alguns indicadores de que não possuímos nosso corpo. Nesta (re)produção compulsória, de nutrirmos um corpo para o outro, é que partimos para experimentos artísticos apoiadas pela crítica das estruturas e agenciadores que dominam o corpo das mulheres.

Nossa primeira experiência ocorreu depois de observar e desenhar as modificações do corpo durante o tratamento contra o câncer, e a ferramenta de auxílio, neste processo, se deu através do obturador da câmera fotográfica.

\subsection{Práticas de si}

Oncológica, Ciclo I, foi uma série de autorretratos que visava provocar, por meio da imagem distorcida, a forma como nós vemos. O embate, naquele momento, transitava em deixar o modelo anterior do corpo para compreender outras perspectivas, a partir da nova configuração inventada. Neste sentido, buscávamos um outro entendimento do corpo compreendendo a força dos agenciadores neste novo paradigma.

As imagens produzidas em preto e branco $(\mathrm{p} \& \mathrm{~b})$ percorreram exposições em alguns estados do país ${ }^{93}$ e distanciavam a visão dos contornos definidos para um difusor ${ }^{94}$ de visão turva, desviando o imaginário de si para um contexto maior de apropriações e imagens construídas pelo social. O não reconhecimento da feição de si seguiu, os relatos e efeitos físicos que, segundo elas, provocavam um embaralhamento das lembranças de como eram fisicamente e como estavam durante o tratamento. Guasch (2009) lembra que LeWitt construiu um catálogo de sua autobiografia sem nenhum autorretrato, buscando retratar objetos que compunham sua trajetória e concepção do vivido, com outros elementos de si mesma. As zonas do vivido ativadas pelas imagens fotográficas projetavam novas possibilidades de representação e, para as feministas, serviu como ferramenta para alçar novas formas de inserção delas no campo social de representação. As imagens de transformações físicas em decorrência da luta contra o câncer ganharam força nas publicidades midiáticas e também nas campanhas de beleza. Inversamente ao que as feministas buscavam, esses agenciadores captaram este disparador como um produto de investimento capital. A luta contra o câncer se tornou slogan e, diferente dos lenços das Madres e Abuelas, o emblema da

\footnotetext{
93 A serie fotográfica percorreu os estados: Rio de Janeiro, Minhas Gerais, São Paulo e Tocantins. E também teve algumas imagens publicadas na Revista Farpa, Ed 1: Salvador, 2015.

${ }^{94}$ Utilizamos como referência a iluminação distribuída no espaço da imagem a ser captada.
} 
luta do câncer nasceu pelo interesse publicitário e econômico. Assim, como aconteceu na campanha publicitária do câncer de mama, muitas lutas foram cooptadas pelo mercado publicitário, como forma de lucrar com assuntos de ordem social.

No autorretrato, além da composição da narrativa pela vestimenta, maquiagem e expressão, há também a referência ao local, como cenário de um indicativo que envolve o espectador e a criação, ao relacionar reminiscências acionadas pela memória visual. As conexões oriundas dessas composições e arranjos estéticos por intermédio da cor, textura, cenário, luz, trajes, ação e o que mais a imagem ofertar sem compromisso com a verossimilhança, possibilitam a construção de uma narrativa de si para o outro e, desta forma, torna livre qualquer associação.

No contexto dos movimentos de protesto, a fotografia, segundo Taylor (2013), pode servir para muitas funções: seja para perseguir agressores, identificar pessoas e inserir composições familiares de pessoas ausentes; seja para reativar momentos não vividos com pessoas já falecidas. Acima de tudo, a fotografia legitima uma situação, tornando-se aliada aos fatos. É neste sentido que o local em que se inserem as imagens passa a validá-las de forma contextual, ou seja, na medida em que apresentam imagens em determinados locais, suas funções e leituras podem ser reformuladas a favor ou contra aquele contexto captado.

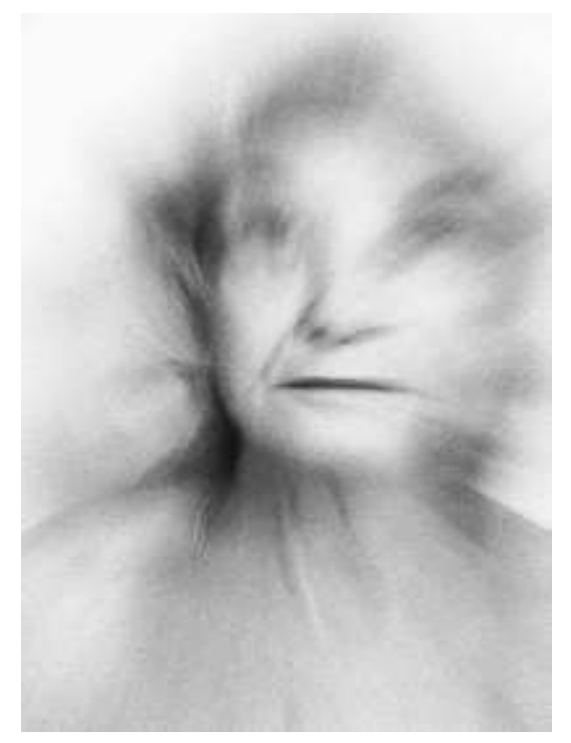

Figura 26. Oncológica: Ciclo I. Foto: Flaviana Benjamin. 
Depois da série fotográfica, seguimos com experimentos que focavam a experimentação do corpo, numa tentativa de buscar relação com outras mulheres e dialogar com as emergências delas em outros locais de atuação. Distante do ambiente hospitalar, a ação performática pretendia seguir com o Movimento de Luta das Mulheres no Brasil. No dia 8 de março de 2015, três anos depois do início do trabalho, Oncológica: Ciclo I, debruçamonos, ainda mais, sobre possíveis experimentos autobiográficos oriundos do câncer materno. Assim, inserimo-nos na programação cultural da Marcha das Mulheres. Tratava-se de uma ação solo, de cunho relacional.

Para Romano (2009), as performances femininas autobiográficas se preocupavam, em 1970, com o espectador. A maioria, naquele momento, estabelecia ações de forma relacional, numa espécie de jogo em que o espectador era trazido como coautor.

\subsection{Incidências do eu no Brasil}

Em 2000, mulheres se reuniram contra a violência e a pobreza, após o chamado 2000 razões para marchar contra a pobreza e a violência sexista ${ }^{95}$, que deu origem a muitas ações com início no dia 8 de março e que foram até o dia 17 de outubro do mesmo ano. Isso se deu depois do chamamento inspirador das mulheres do Quebec/Canadá, que moveram 850 mulheres para marchar e percorrer 200 quilômetros. Neste percurso, conversavam com os passantes, pedindo Pão e Rosas. A estratégia, simbólica, provocou mobilizações nas ruas que tinham como fio condutor a crítica ao capitalismo. A estratégia não apenas funcionou, como irradiou em outros países. Esta ação rendeu às mulheres imigrantes do Quebec melhorias no

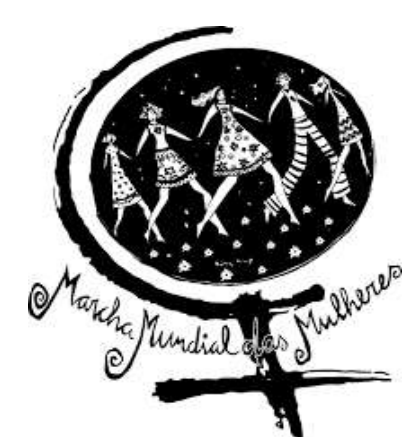

Figura 27. Marcha Mundial das Mulheres. Foto: Divulgação. salário mínimo e apoio econômico solidário. No Brasil, deu origem à Marcha Mundial das Mulheres (MMM), composta por mulheres urbanas e rurais que têm, como base, as alianças feitas com movimentos socais já fixados. A relação com estruturas de dominação, como capitalismo patriarcal, racismo, homofobia e violência destruidora do meio ambiente, são pilares de luta e visão da MMM. Elas buscam "construir uma perspectiva feminista afirmando

$$
-
$$

95 Disponível em: http://www.marchamundialdasmulheres.org.br/a-marcha/quem-somos/. Acesso em: 24/07/2018, às 15 h51. 
o direito à autodeterminação das mulheres e a igualdade como base da nova sociedade que lutamos para construir" 96 . Presente em mais de 20 estados brasileiros, a Marcha propõe aproximação das mulheres na rua e não segrega "movimento de mulheres e (...) movimento feminista"97.

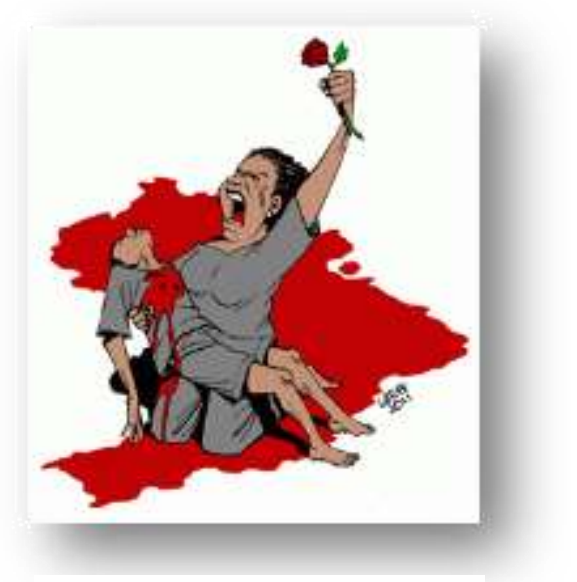

Figura 28. Mães de Maio Cartunista: Latuff.
A partir deste movimento acolhido por outros movimentos já fixados ou em formação, que, por vezes, são conflitantes em determinadas linhas do feminismo, ampliam o movimento das mulheres em vários seguimentos. Próximo às Madres e Abuelas, há o movimento de mulheres referente à Chacina da Candelária $^{98}$ (Rio de Janeiro), com mais de 20 anos, mas com efeito pulverizado, pois as mães parecem sentir efeitos das ameaças e não conseguem força para mobilizar o país, mesmo com o apoio das Mães de Maio ${ }^{99}$.

A Marcha Mundial das Mulheres, no Brasil, muitas vezes, tem ligações políticopartidárias e, no dia 8 de março, levantam-se acampadas por outras bandeiras de organizações e seguimentos. A divisão espacial dessas bandeiras e suas representantes acontece na rua, em São Paulo; geralmente, ocorre na Avenida Paulista em meio ao trânsito e no contrafluxo das pessoas. Caminham em espaços auto-organizados, a partir destas identificações de coalisões com a multiplicidade de camadas que envolvem a organização das mulheres neste dia. Em comum, propõem a melhoria e a equalização dos direitos ao trabalho, legalização do aborto, desmercantilização da sexualidade, combate ao feminicídio e à violência doméstica, apoio à Lei Maria da Penha (do ano de 2006), à autonomia da mulher, lutam contra o patriarcado, além de trazerem pautas relacionadas à política temporal, como, por exemplo, os gritos de

\footnotetext{
${ }^{96}$ Ibidem.

${ }^{97}$ Ibidem.

${ }^{98}$ Crime ocorrido em 1993, em frente à Igreja da Candelária no Rio de Janeiro, que matou 8 jovens em situação de rua. Dentre eles, 6 jovens menores e 2 maiores de idade. A investigação, após a chacina, confirmou envolvimento de policiais militares no assassinato. A chacina deu origem à manifestação das mães que tiveram seus filhos mortos neste dia.

Fonte: https://fotospublicas.com/missa-na-igreja-da-candelaria-em memoria-a-

chacina-ocorrida-ha-22-anos/. Acesso em: 24/07/2018, às 22h47.

99 Sequência de assassinatos ocorridas no mês de Maio de 2006, em confrontos entre o Estado e a organização criminosa/ilegal PCC (Primeiro Comando da Capital), que teve como consequência centenas de pessoas inocentes mortas (todas comprovadas legalmente) por policiais no estado de São Paulo. Disponível em: http://maesdemaio.blogspot.com/. Acesso em: 24/07/2018, às $22 \mathrm{~h} 34$. Fonte de imagem (Figura 27): http://marchamundialdasmulheres-rj.blogspot.com/2012/05/reuniao-da-mmm-rjdia-15-de-maio.html. Acesso em: 24/07/2018, às 22h59.

Fonte de imagem (Figura 28): http://maesdemaio.blogspot.com/2014/07/importantissimo-nesta-quinta-feira1007.html Acesso em: 24/07/2018, às 22h26.
} 
Fora Temer, Golpe, Não à Reforma Trabalhista e Reforma da Previdência ${ }^{100}$ etc. Estes são alguns temas que caminham no contexto das reivindicações das mulheres no dia 8 de março na Avenida Paulista/SP atualmente.

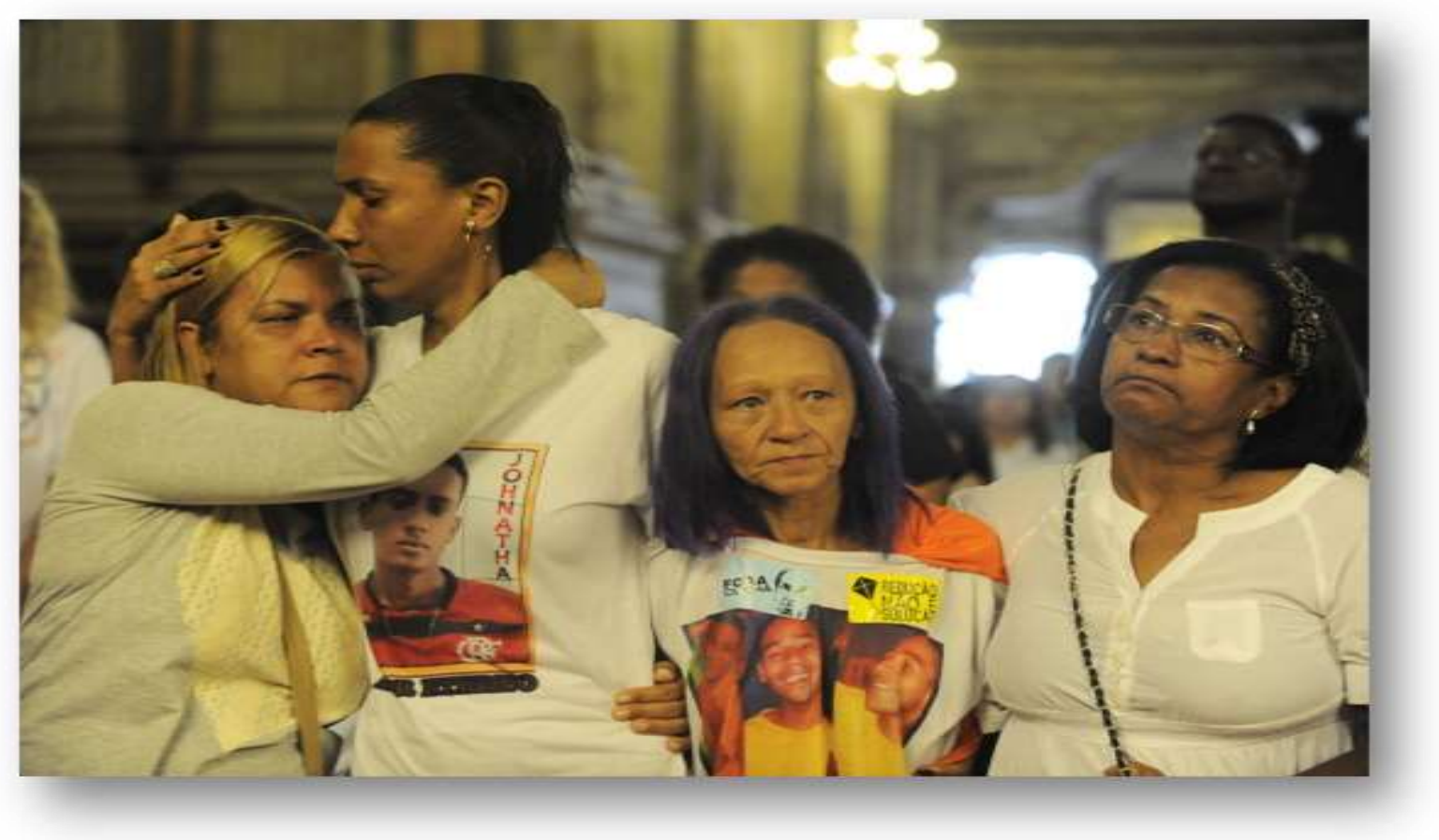

Figura 29. Mães da Candelária. Foto: Tânia Rego/Agência Brasil.

Neste contexto, realizamos a performance intitulada Oncológica: Ciclo III, que propôs a ação de (des)costurar demarcadores de gênero no corpo, a fim de criar junto a ação de alinhavar/desalinhavar um corpo que não necessariamente reproduzisse o determinismo de gênero em um viés binário (masculino/feminino). Caso construísse: Qual peso desta construção compulsória na rua, composta por mulheres que clamam por mudança?

Para inserir a performance no Movimento, houve, por parte das integrantes da MMM, um anúncio da ação. Pelo microfone e amplificadores de som, as mulheres anunciavam ações e também falavam de acontecimentos no país e reinvindicações em uma espécie de formação pública na Avenida.

\footnotetext{
${ }^{100}$ Frases de reinvindicação social, que nasceram em 2016, após o golpe que colocou Michel Temer como novo presidente do Brasil, mesmo sua posse sendo contestada e negada pela população.
} 


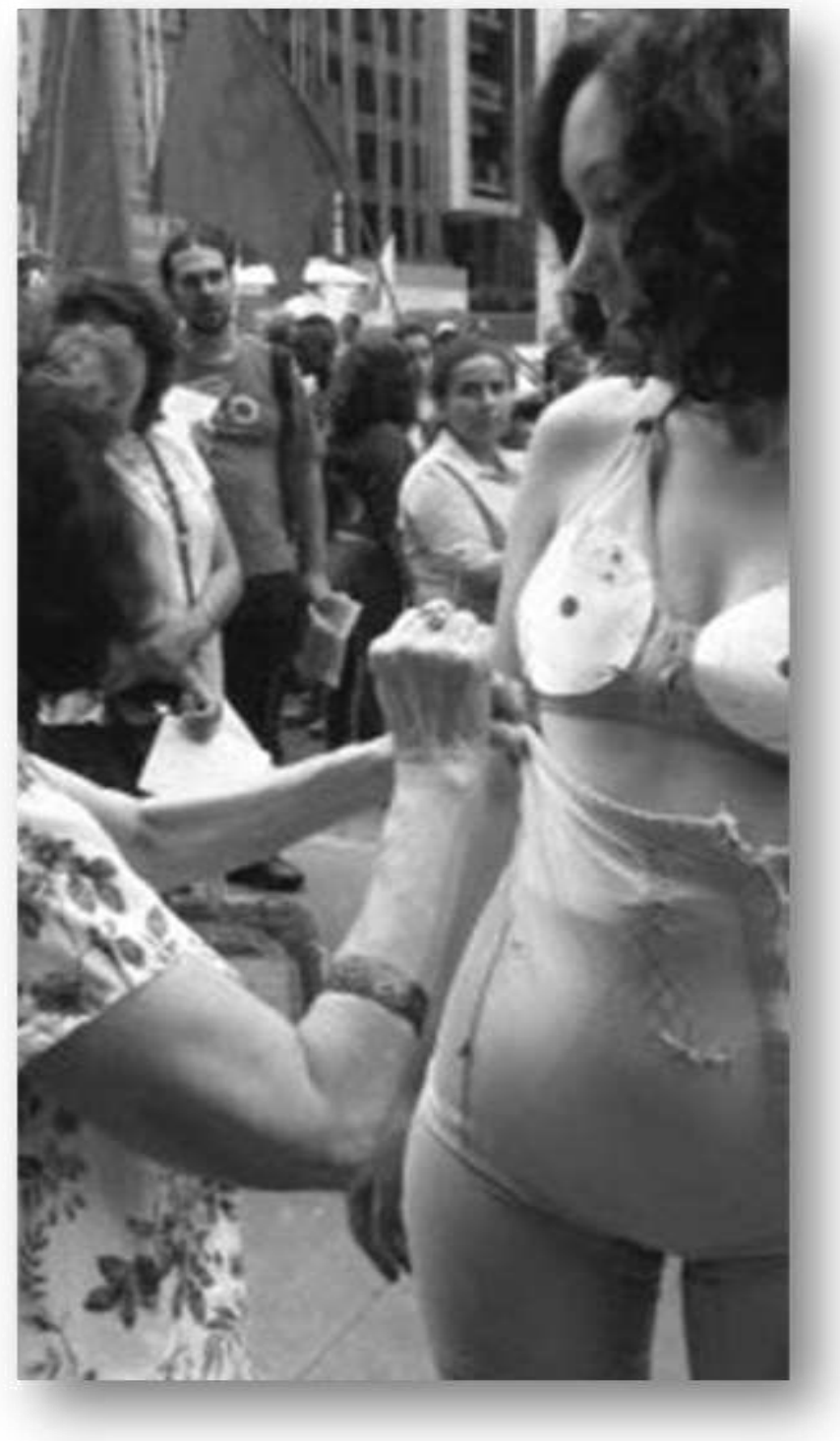

Figura 20. Registro de Performance - Oncológica: Ciclo III. Foto: Ellen Paula.
A ação durou em média 3 horas e teve, entre seus participantes, crianças, mulheres, homens e observadores. Em princípio, houve uma preocupação das passantes em acolher a ação, entender e, de alguma forma, estabelecer diálogo. Depois, a criação de origem autobiográfica ganhou o espaço da rua e o indizível buscou compor a linha tênue junto às camadas entre múltiplas realidades e autorrepresentações e, as participantes, começaram a interagir e narrar suas histórias pessoais. As nuances destas instâncias variavam e se ressignificavam a cada local da ação. Próximo a edifícios ou compondo alguma imagem fotográfica de mulheres vítimas de violência doméstica, a ação era composta também por aquela informação. Multiplicando as ações autobiográficas de um agente solo para um agente disseminador. Neste aspecto, concordamos com Larrosa:

A construção e a transformação da consciência de si dependerá, então, da participação em redes de comunicação onde se produzem, se interpretam e se medeiam histórias. Dependerá desse processo interminável de ouvir e ler histórias, de contar histórias, de mesclar histórias, de contrapor algumas histórias a outras, de participar, em suma, desse gigantesco e agitado conjunto de histórias que é a cultura. A constituição narrativa da experiência de si não é algo que se produza em um solilóquio, em um diálogo íntimo do eu consigo mesmo, mas em um diálogo entre narrativas, entre textos. $\mathrm{Na}$ aprendizagem do discurso narrativo através da participação em práticas discursivas de caráter narrativo se constitui e se modifica tanto o vocabulário que se usa para a autodescrição quanto os modos de discurso nos quais se articula a história de nossas vidas. É no trato com os textos que estão já aí que se adquire o conjunto dos procedimentos discursivos com os quais os indivíduos se narram a si mesmos. O processo pelo qual se ganha e se modifica a autoconsciência não se parece, então, com um processo de progressivo descobrimento de si, com um processo em que o verdadeiro eu 
iria alcançando pouco a pouco transparência para si mesmo e iria encontrando os meios linguísticos para expressar-se. A consciência de si própria não é algo que a pessoa progressivamente descobre e aprende a descrever melhor. E, antes, algo que se vai fabricando e inventando, algo que se vai construindo e reconstruindo em operações de narração e com a narração (LARROSA, 2008, p. 70-71).

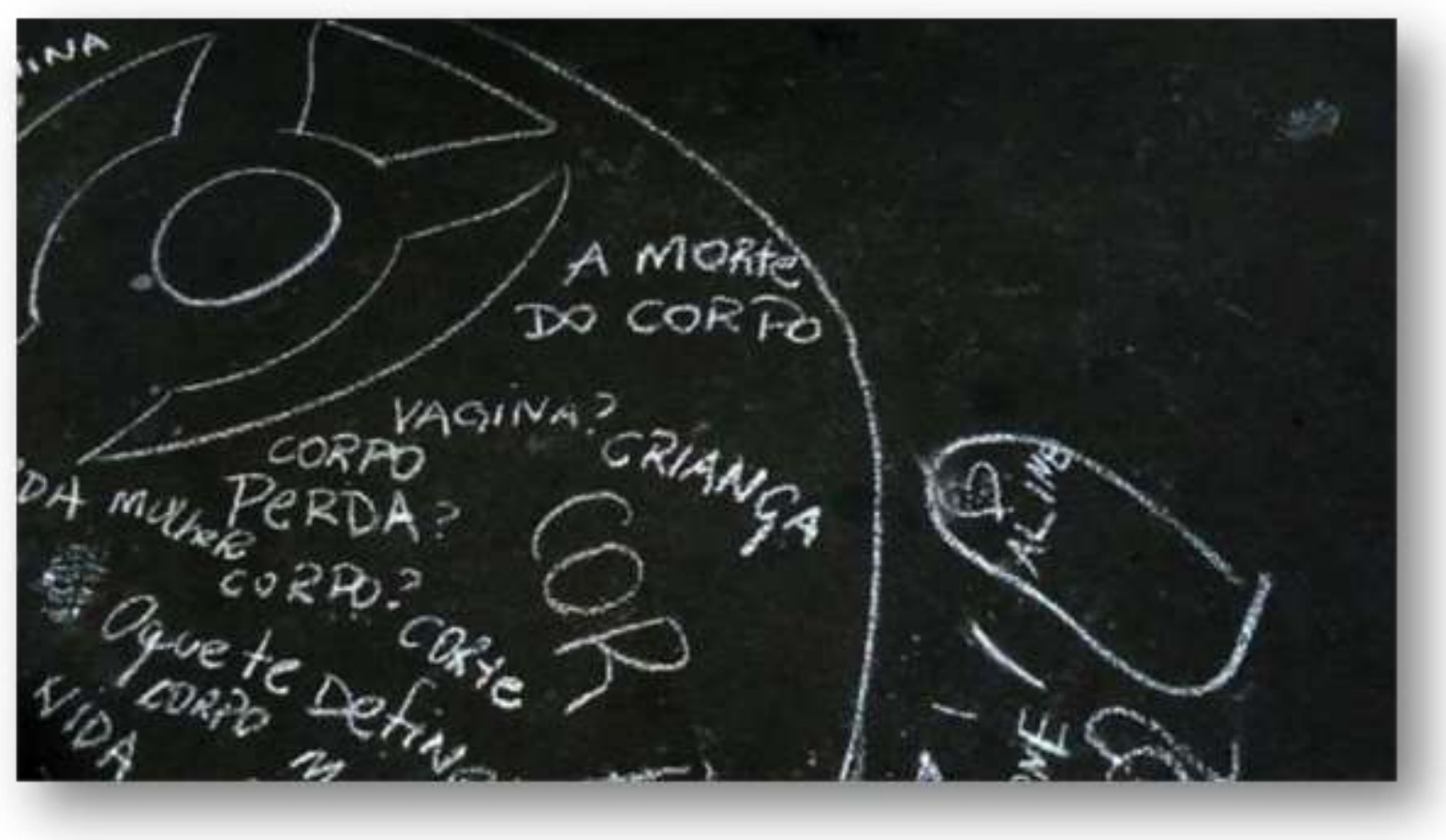

Figura 31. Registro de Performance - Oncológica: Ciclo III. Foto: Ellen Paula.

Neste sentido, este outro agente não parte da mesma premissa, mas compõe, a partir da sua singularidade, uma pluralidade narrativa e visual de inquietações. Entre meandros, evidenciam histórias múltiplas, mas com disparador solo e autobiográfico. A configuração de outras tramas narrativas se dá por meio do deslocamento e relação com os passantes que veem, na célula da ação performática, um dispositivo relacional de histórias e experiências. 


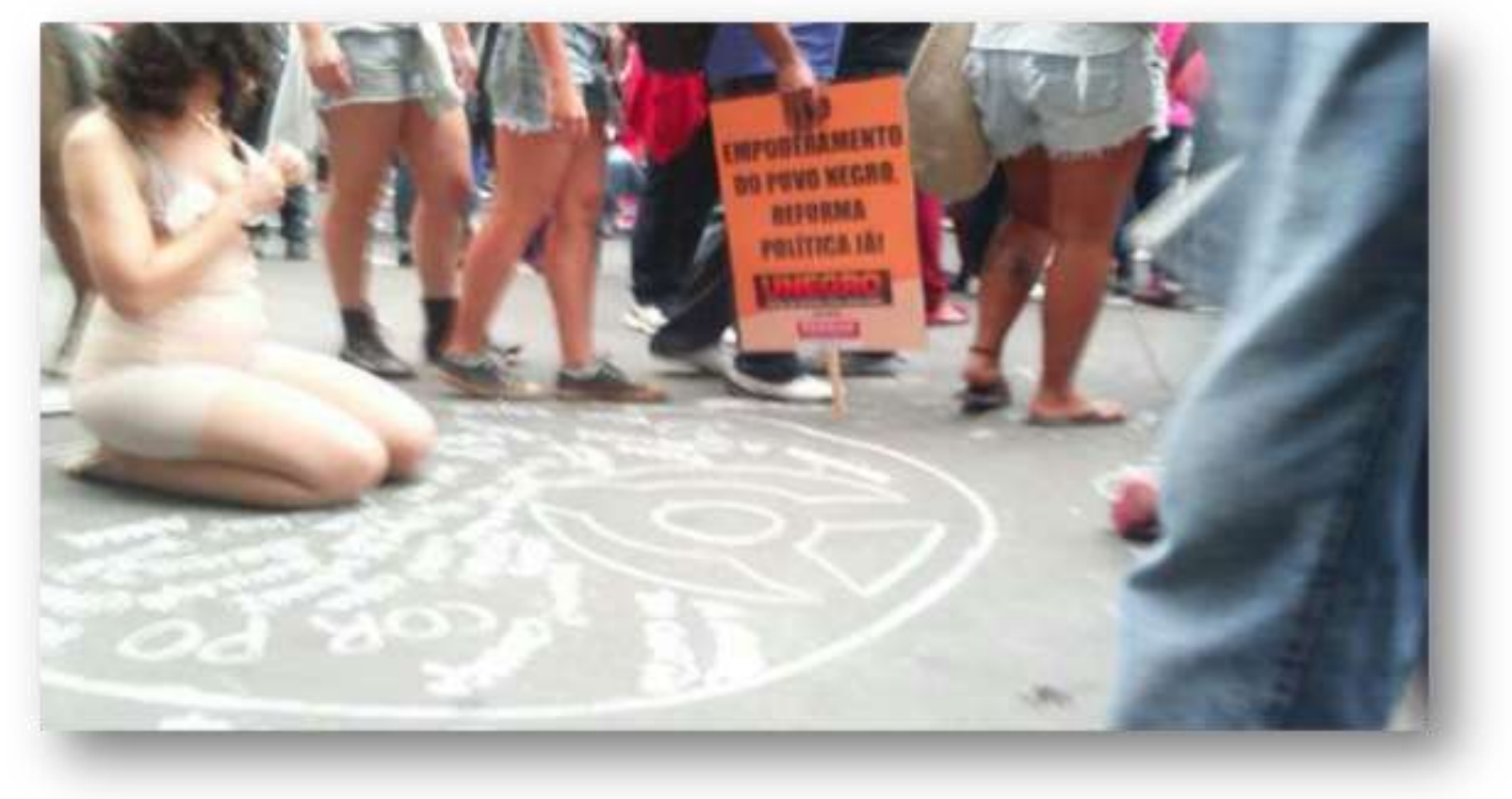

Figura 32. Registro de Performance - Oncológica: Ciclo III. Foto: Ellen Paula.

\subsection{As tecnologias de si}

Depois do longo percurso sobre os mecanismos de controle, Foucault traz As Tecnologias do Eu (1990) e aborda as operações sobre os corpos, almas e pensamentos, numa perspectiva individual, a fim de revelar os sistemas de controle e os efeitos de permanência dessas estratégias nas sociedades, ou seja, como imersos aos sistemas de controle, normas e valores, conseguimos resistir ou não à disciplinarização.

Larrosa (2008) argumenta que Foucault revelou que todo e qualquer discurso é atravessado pelo poder e, desta forma, as diversas organizações que substancializam os discursos revelam que as práticas discursivas também se inserem como práticas sociais organizadas e demonstram relações em desiquilíbrio e, por vezes, em desigualdade. Desta forma, a miríade de operações de controle e poder compõem as autonarrativas, revelando-as, ainda de forma naturalizada, como parte dos sistemas de controle, e diagnosticando os sistemas de "uma história social e uma história política” (LARROSA, 2008, p. 71).

O roteiro da performance, ao desenrolar-se na rua, junto aos passantes e envolvidas no movimento de protesto, buscava relações possíveis. Diante de tantas mulheres que problematizam os discursos e agenciamentos do corpo, tentava criar composições corporais que refletissem e problematizassem a representação compulsória do corpo fruto do 
determinismo biológico e da sexualização. Ao passo que a experiência simbólica poderia também romper, por meio do jogo e da singularidade performática, a construção social do corpo feminino, que desmistificasse o corpo da mulher ao ponto de compor um ser andrógino, que não se apoiasse na objetificação sexual atrelada ao corpo feminino como resultado de uma visão determinista. No entanto, ao se depararem com um corpo vivo a ser moldado, a ânsia se dava em compô-lo seguindo a expressão de gênero feminino. $\mathrm{O}$ afã de remodelar o corpo feminino em feminino era desencadeado nas diversas relações estabelecidas na rua durante o protesto. Identifica-se aqui a força dos mecanismos de controle, que operam em todas as esferas sociais e, a partir desta reprodução compulsória, reforçam o que Foucault diagnosticou como teleologia do sujeito moral $^{101}$.

Por mais que existam comportamentos e expressões desviantes do binaríamos de gênero, ainda assim, sua representação marcada pela performatividade de gênero é reforçada e mantida a cada repetição de ações cotidianas, através da dicotomia de gênero, que está enraizada no imaginário social. Os passantes reconstruíram o corpo ancorados pela visão compulsória, como reflexo da influência hegemônica do binarismo de gênero.

Assim, qualquer manifestação atrelada à liberdade do corpo, como a luta das mulheres na Argentina, que também chega ao Brasil marcada pela onda verde, talvez se depare com o desafio de abordar as dicotomias representacionais entre homem e mulher. O assunto como pauta social, a política educacional e a crítica social passam a ser desafiadas a construir novas maneiras de caminhar com os implicados em um processo de responsabilidade. Sobre isso, o debate educacional na Argentina traz as questões da Lei de Descriminalização do Aborto para as escolas, como espaço de reflexão não apenas sobre questões das mulheres, mas reflexão crítica e responsabilidade aos implicados. O cruzamento da história social e história política, como apontou Larrosa, pode dar margem para um comprometimento com início na singularidade e que envolva o coletivo em novos paradigmas.

Em outra chave conceitual, Cornago (2009) vai fazer uso das tecnologias do eu deixadas por Foucault junto às premissas relacionadas ao depoimento pessoal com relação as novas mídias, em que os dispositivos de atuação (câmera, celulares, tablets, webcam) vão somar nas produções artísticas e sociais, dando a elas um caráter verossímil.

O uso recorrente das imagens estáticas (fotografia) e imagens em movimento (vídeo) aparecem nas produções artísticas como fio condutor das experiências autobiográficas e acoplam, através destes dispositivos, depoimentos, relatos, fatos que dão à ação artística

${ }^{101}$ FOUCAULT, Michel. História da sexualidade 2: o uso dos prazeres. Rio de Janeiro: Edições Graal, 1984. 
composição estética de verossimilhança, nas imediações que potencializam as representações na fronteira com o real.

\subsection{Memória política}

No percurso da performance Oncológica, junto com a MMM, identificamos proximidades na ação participativa presente também nos movimentos de protestos ocorridos no Brasil e Argentina (Abuelas, Madres e H.I.J.O.S), nos quais é possível, identificar uma esfera singular, saltar para relações do coletivo. Na medida em que a história solo é também compreendida pelo outro, seja pela semelhança ou pelo pacto, o coletivo toma nota de assuntos urgentes para a população. E, neste encontro, o contexto social é potencializado mediante as identidades individuais. E, assim, "são formadas narrativas populares [...] por meio da criação e elaboração artística" "102 (ECHENIQUE, 2013, p. 7), seja através do rechaço, interferência indicativa nas placas de rua, grafites, ações repetidas semanalmente, permanência em dia e horário regular ou adornar fraldas em memória de familiares desaparecidos. Na somatória de interferências singulares que compõem outra maneira de contar a lembrança do vivido é (re)significada mediante ações e estratégias dos movimentos de protesto, seja no Brasil ou na Argentina. Desta maneira, fatos não documentados somam como suporte de objetos imagéticos, narrativas silenciadas ou ignoradas pelo social. Aos movimentos de protesto, cada participação singular intensifica a memória do coletivo, em uma formação a partir das narrativas e autorrepresentações encontradas de uma memória política dos fatos ocorridos. Para tanto, toma, como aporte, as narrativas dos corpos silenciados ou que foram vitimados pelo poder, e que não conseguem, nas instancias legais, a justiça que desejam. No entanto, na rua encontram um lugar para ecoar o reconhecimento das violências e atrocidades vividas.

Un colectivo que guarda en su acervo historias, que entre otras cosas, exigen un reconocimiento social, sobre todo por que se trata de historias cuyos contenidos han sido elaborados y expresados de forma simbólica hacia la comunidad, para todos por igual, como son los murales callejeros y sus elaboraciones simbólicas. Es esta trenza de contenidos, alojada en la periferia, capaz de organizarse políticamente, alejada de los poderes centrales, puja hasta emerger como relato (de un tipo u de otro). [...] por estos contenidos,es el sistema que termina permitiendo, que por su intermedio, se complejice um flujo social adoptando un lenguaje artístico y

${ }^{102}$ Tradução nossa. No original: "narrativas populares [...]por medio de la creación y elaboración artística. 
facilitando que se produzca la reelaboración y la emergencia de esta cultura subterránea, identitaria y autónoma (ECHENIQUE, 2013, p. 7-8).

Neste contexto, Caballero (2011) ressalta que as indagações das mães dos desaparecidos serviram de forro para restaurar memória ao cenário político, ao confrontarem narrativas de generais e figuras do poder que atuaram em decisões unânimes. Os integrantes dos movimentos de protesto não apenas conseguem rever situações de violência, mas também criam outras perspectivas de uma mesma situação. Ao rever fatos, instaura-se uma responsabilidade de memória política no coletivo. Soma-se a isso composições estéticas de intervenção no espaço, as representações artísticas (carnavalescas, escraches, performances [...]) e a composição urbana que atua como palco ao cenário da política da memória.

Recorrendo mais uma vez a Caballero, que reitera como "duplo registro o íntimo e o social" (CABALLLERO, 2011, p. 83), como relatos selecionados para serem reapresentados para um coletivo. Neste aspecto, entram em construção as narrativas cênicas de autoficção e/ou construção de personagens na absorção das práticas teatrais, através da memória política trazida pelas autoexpressões, narrativas de si, autorrepresentações, permitindo a criação de novas perspectivas narradas. Somam-se a isso a fotografia e, na atualidade, o filme de autorreferencialidade. Tendo em vista que "a história da autonarração é também uma história social e uma história política" (LARROSA, 2008, p. 7).

\subsection{Da rua para o palco}

$\mathrm{Na}$ trajetória criacional do processo Oncológica, podemos constatar as diversas possibilidades das relações íntimas e familiares que despontam do autobiográfico e revelam diagnósticos sociais. O que inicia na esfera privada (casa) das relações familiares e fora dela, no ambiente da rua, intensifica a responsabilização de políticas públicas que não restringem apenas as esferas do campo social, mas, por elas, influenciam as estéticas artísticas.

A variedade de possibilidades que se abrem na incidência dos teatros do real ${ }^{103} \mathrm{em}$ uma configuração tardia, depois da grande eclosão no campo do cinema, artes visuais e performance arte. Na Argentina destacamos Vivi Tellas, exemplar nos indícios das escritas de si a partir da teatralização da vida, que ela denomina como biodrama. Destacamos que sua

${ }^{103}$ FERNANDES, Silvia. Experiências do real no teatro. Sala Preta, Brasil, v. 13, n. 2, p. 3-13, dec. 2013. ISSN 2238-3867. Disponível em<http://www.revistas.usp.br/salapreta/article/view/69072>. Acesso em: 26/07/2018. 
pesquisa teve início no ano de 2001, em meio à intensa crise e participação da população nos movimentos de protesto. Neste cenário, sua majestosa contribuição entre arte e vida na teatralidade se desdobrou no que chama de documentos cênicos. Sobre isso comenta:

Biodrama se inscríble em torno a lo que se podriá llamar el 'retorno de lo real' em el campo de la representación. Después de casi dos décadas de simulaciones y simulacros, lo que vuelve - en parte como oposición, en parte como reverso - es la idea de que todavia hay experiencia, y de que el arte debe inventar alguna forma nueva de entrar em relación com ella. La tendência, que es mundial, compreende desde fenómenos de cultura de massa, como los 'reality shows', hasta las expressiones más avanzadas del arte contemporâneo, passando por la ressureccíon de géneros hasta ahora 'menores', como el documental, el testimonio o la autobiografia. El retorno de la experiencia - lo que em Biodrama se llama 'vida' - es también el retorno de Lo Personal. Vuelve el Yo, sí, pero es um Yo imediatamente cultural, social, incluso político (Tellas, 2017, p. 13-14).

Depois dela, Lola Arias parte da linguagem teatral e se lança nas artes visuais, performance arte e vídeo, tendo como premissa pessoas que emprestam suas experiências (auto)biográficas para compor um duelo cênico, no choque entre os tempos. Pessoas que viveram situações extremas no passado são convidadas a reproduzir experiências em um salto temporal, e são imbuídas a reviver momentos de agonia frente a seus agressores do passado, que agiam direta ou indiretamente em fatos traumáticos.

Neste embate do tempo, passado e presente se encontram para trazer ao espectador um diagnóstico de exercício de alteridade, por meio de novas perspectivas de fatos sociais ocorridas no passado. O último espetáculo teatral da artista - Campo Minado (2016) acolheu veteranos opositores (argentinos e ingleses) da Guerra das Malvinas, em uma experiência cênica. As diferenças não apenas no campo discursivo, mas na ação dos veteranos, que carregavam nas mãos sangue dos muitos mortos neste período, demonstram como a arte tem acolhido as questões atreladas ao social. Desta maneira, o teatro no Brasil segue o mesmo caminho.

Um dos maiores pesquisadores sobre teatro documentário, o diretor Marcelo Soler, segue nas manifestações em torno da vida como componente das manifestações cênicas no Brasil. Janaina Leite, com o teatro autobiográfico, experimenta desmembramentos que friccionam as fronteiras do real. Exemplares também são Cia Hiato, Cia Zula de teatro (Belo Horizonte/MG), Vanessa Macedo, diretora da Cia Fragmento de dança, que propõe tratar o autobiográfico em partituras solo ou coletiva, em estruturas fechadas, e muitos outros que somam nas representações do eu na cena contemporânea. O que parece ser um segundo passo 
desta influência são os recortes de gênero, seguidos dos debates em torno do étnico-racial, deslocando para as referências do Cone Sul, em que a colonização será material de novos desafios para a arte e suas linguagens.

\subsection{Do que não se finda}

Em entrevista, Margareth Rago fala que o poder não almeja o corpo dócil, como Foucault tinha anunciado em Vigiar e Punir (1975), mas o sujeito autônomo. Certamente os novos desafios não serão únicos, mas múltiplos. Aparecem na medida em que esses grupos ganham espaços e novos dispositivos de controle são lançados para a manutenção da dominação e do poder hegemônico. Os grandes desafios seguem as linhas emancipatórias (feminismo, pós-feminismo, teoria queer, de/descolonial, o especismo, etc.) que exigirão adaptações e desapegos do muito que nos foi fornecido como técnica e referencial teórico.

$\mathrm{Na}$ medida em que as mulheres começam a ganhar espaços e equidade de direito, a arte realizada e feita por elas passa a ganhar novas diretrizes estéticas. O que resta é entender como a América Latina ou como os grupos não hegemônicos irão, estrategicamente, cultivar espaços, e como artistas irão receber novas formas do fazer. Se as questões atreladas ao eu permanecerão no interesse da arte contemporânea ou se ainda receberemos as formas estéticas ocidentais, não sabemos, mas podemos acrescentar aqui que isso certamente será material de discussão. 


\section{CONSIDERAÇÕES FINAIS}

O vasto uso da autobiografia ganha diretrizes contestatórias no tocante às mulheres. Os embates são fortalecidos por meio das correntes feministas e são orquestradas pela teoria crítica literária que enfrenta as diretrizes apresentadas por Barthes e Foucault em ensaios sobre autoria. As mulheres, impulsionadas por ensaios polêmicos, como proposto por Stanton sobre autoginografia, partem, para articular e questionar espaço destinado comumente aos autores. Na mesma via, mas datado aproximadamente dos anos de 1970, a performance arte, dá força motriz às representações autobiográficas, influenciada pelas lutas feministas, que vê, neste levante, novas linhas de experimentação. O corpo e a body art apresentam sustentáculos precisos para que as mulheres e seus corpos forneçam material de criação através de estéticas radicais, numa série de desvios, ao identificar a arte como formas e expressões enrijecidas.

A autobiografia, tratada por meio de temas na literatura, auxilia as mulheres na organização e em espaço de circulação: ao desprenderem-se do papel e do ambiente doméstico (privado), passam a ocupar a rua. A narrativa pessoal, muitas vezes carregada de mazelas, revela as diversas fraturas sociais que a fio se chocam entre real e ficcional ou, como aponta Das (2007), na urgência da voz enfraquecida operam mais no mostrar do que no falar. O mostrar não aparece apenas nas narrativas reivindicatórias, mas na construção diária dos modos de viver. No levante, os dizeres buscam formas e materialidade ao encontrarem nas linguagens artísticas possibilidades do indizível.

Da solitude do papel às escritas de si, iniciam-se nas manifestações solos como autoperformances (KIRBY, 1979), por vezes de cunho e preocupação relacional e, por outra, ancoradas pelo desejo de trazer para a cena artística vozes silenciadas, por intermédio da estética feminista (TVARDOVSKAS, 2015), que se apoia na idiossincrasia do elo entre arte e vida, experiência e arte e produção subjetiva como possibilidade de subversão.

No espaço das lutas feministas e da performance arte, as mulheres ganham maior força de representação para debater pautas e fragilidade. Pela arte, o indizível e o incompreendido passam a questionar a norma e os construtos sociais, a partir das experiências de confrontação. Neste aspecto, o uso do corpo (em confronto) traz assuntos como sexualidade, gravidez, violência, e revelam que o corpo feminino é um território marcado pelo poder ${ }^{104}$. Estes temas são debatidos em performances exemplares, como apresentamos no $2^{\circ}$ capitulo,

${ }^{104}$ FOUCAULT, Michel. Microfísica do poder. Rio de Janeiro: Edições Graal, 1979. 
nas ações solos e singulares. O pacto, apontado nesta pesquisa a partir de Lejeune (2014), contribui também para entender a multiplicação da singularidade que revela, através de dois pilares - fidelidade dos fatos ocorridos por meio da história pessoal e identificação (alteridade) nos movimentos de protesto -, a dilatação do singular. O corpo singular ganha intensidade no corpo coletivo, na perspectiva de busca por direitos. Sobre isso, tomamos as ruas de Buenos Aires como campo de pesquisa para traçar relações com o Brasil, a partir das manifestações e coletivos de mulheres. Neste aspecto, a colisão com as figuras do poder faz surgir, por interferência delas, insubordinações em momentos de fragilidade. Mapeamentos, estudos e formas de circular em lugares públicos no indicativo dos modos de resistir e operar.

Emanados pelo contexto histórico e político, os países Argentina e Brasil exibem aproximações e distanciamentos em relação a elas, mas em uma guinada trazida, pela Argentina, pelo atual presidente Macri, nos fornece pistas para relacionar os diversos caminhos encontrados pelas mulheres (argentinas e brasileiras). Neste cruzamento, alçamos a autobiografia solo, delas, como multiplicadora (coletivo) de vozes silenciadas pela escrita social, política, cultural e econômica. Este percurso parte de uma doença familiar (mãe) e seus desdobramentos artísticos intitulado Oncológica, pela artista e pesquisadora, revelando experimentações artísticas que saltam da singularidade como processo de subjetivação e que também atuam nos movimentos de protestos (rua) como modos de existir e lutar. A experimentação, que teve diversos desdobramentos, constitui-se como processo artístico depois do longo percurso solo que encontra na rua, sua relação mais análoga entre iguais e diferentes. Neste caminhar, os movimentos de protesto dão suporte para experiências que se relacionam com fatos e estetizam situações limítrofes como possibilidade de debate sobre temas inaceitáveis pelo social. A exemplo disso, abordamos os trâmites da descriminalização do aborto, debate mais recente em Buenos Aires/Argentina, como tema de rechaço social. Seus sustentáculos mantidos pelo poder (Estado) e pelas correntes religiosas atuantes no corpo da mulher de forma severa e punitiva, seja na ordem física ou psicológica de culpabilização. Neste aspecto, elementos estetizados, poderia viabilizar um debate aceitável, pois o limiar não claro entre ficção e realidade seria capaz de validar discussões que, no campo do real, são objetadas imediatamente.

Nas experimentações artísticas de cunho autobiográfico, no que concerne às mulheres, é possível identificar o esforço delas e as artimanhas do poder nos desvios e avanços. É visível, na América Latina, os manejos encontrados, por elas, no Brasil e na Argentina, de sobrevida, marcada pela violação. Trazemos, por meio da experiência singular e, mais tarde, 
junto com coletivos os motins do dizer. A arte, sobretudo a performance arte e seus alicerces nos campos de enunciação, escuta e fazer das mulheres e na responsabilização dos implicados. Na fricção, arte e vida, os desdobramentos artísticos ou em movimentos de protesto trazem, à testilha diária, permanência e manutenção de vida na história inenarrável. 


\section{REFERÊNCIAS}

ARFUCH, Leonor. O espaço biográfico: dilemas da subjetividade contemporânea. Rio de Janeiro: EdERJ, 2010.

BARROS, Roberta. Elogio ao toque ou como falar de arte feminista à brasileira. Rio de Janeiro: Ed. da autora, 2016.

BARTHES, Roland. O rumor da língua. São Paulo: Martins Fontes, 2004.

BOURDIEU, Pierre. A dominação masculina. Rio de Janeiro: Best Bolso, 2016.

BUTLER, Judith. Problemas de gênero: feminismo e subversão da identidade. Rio de Janeiro: Civilização Brasileira, 2016.

Relatar a si: critica da violência ética. Belo Horizonte: Autêntica Editora, 2015.

Quadros de guerra: Quando a vida é passível de luto. Rio de Janeiro: Civilização Brasileira, 2015

COSTA LIMA, Luiz. Júbilos e misérias do pequeno eu. In. Sociedade e discurso ficcional. Rio de Janeiro: Guanabara, 1986.

DAS, Veena. Life and Words: Violence and the descent into the ordinary. Berkeley: University of California Press, 2007.

DIEGUEZ, Ileana. Escenarios y teatralidades liminales. Prácticas artísticas y socioestéticas. In: Archivo Virtual Artes Escenicas, 2009.

Disponível em: http://artesescenicas.uclm.es/index.php?sec=texto\&id=205. Acesso em: 23/07/2018.

ECHENIQUE, Claudia. Teatro Callejero: Opcíon Estética para la Creación de Memória Política. Pitágoras 500, vol.5, Outubro,2013. Disponível em: https://www.publionline.iar.unicamp.br/index.php/pit500/article/view/138. Acesso em: $14 / 03 / 2018$.

FIGUEIREDO, Eurídice. Mulheres ao espelho: autobiografia, ficção, autoficção. Rio de Janeiro: ed. UERJ, 2013.

FOSTER, Hal. O artista como etnógrafo? In: O retorno do real. São Paulo: Cosac \& Naify, 2014.

FOUCAULT, Michel. O que é um autor?. Lisboa: Nova Vega, 2009.

A vida dos homens infames" in: Ditos e escritos, v. 4. Trad. Vera Lucia Avelar Ribeiro. Rio de Janeiro: Forense universitária, 2006. 
A arqueologia do saber. Trad. L. F. B. Neves. Rio de Janeiro: Forense Universitária, 2008.

Tecnologias del yo - Y otros textos afines. Tradução de Mercedes Allendesalazar. 1a. ed. Barcelona: Paidós Ibérica, 1990.

GAYLE, Rubin. Políticas do sexo. São Paulo: Ubu, 2017.

GILMORE, Leigh. A marca da autobiografia: pós modernimos, autobiografia e gênero. In: KATHEEN, Ashley et. al. Autobiografia e pós-modernismo. Amherest, University of Massachusetts Press, 1994.

GOFFMAN, Erwing. A representação do eu na vida cotidiana. Petrópolis, Rio de Janeiro: Vozes, 2014.

GREENBERG, Clement. Estética Doméstica observações sobre a arte e o gosto. Trad. André Carone. São Paulo: Cosac \& Naify, 2002.

GUAUSCH, Anna Maria. Autobiografías Visuales: del archivo al índice. Madrid: Siruela, 2009.

JEUDY, Henry - Pierre. O corpo como objeto de arte. São Paulo: Estação Liberdade, 2002.

JONES, Amelia. Body art: performing the subject. London: Minneapolis, 1998.

KIRBY, Michael. An Introduction, The Drama Review: TDR, Vol. 23, No. 1, Autoperformance. Issue (March, 1979).

KLINGER, Diana. Escritas de si, escritas do outro: o retorno do autor e a virada etnográfica. Rio de Janeiro: 7 Letras, 2012.

KOLLONTAI, Alexandra. Autobiografia de uma mulher comunista sexualmente emancipada. São Paulo: Editora Sundermann, 2007.

LARROSA, Jorge. Notas sobre a narrativa e a identidade. In: ABRAHÃO, Maria Helena Menna Barreto. A aventura (auto)biográfica: teoria \& empiria. Porto Alegre: EDIPUCRS, 2004.

LEJEUNE, Philippe. O pacto autobiográfico: De Rousseau à Internet. Belo Horizonte: UFMG, 2014.

LEITE, Janaina Fontes. Autoescrituras performativas: do diário à cena. São Paulo: Perspectiva: Fapesp, 2017.

LISPECTOR, Clarice. A Descoberta do Mundo. Rio de Janeiro: Rocco, 1999.

LOPES, Adília. Antologia. São Paulo: Cosac \& Naify, 2002. 
LUGONES, María. Rumo a um feminismo descolonial. Revista Estudos Feministas, Florianópolis, v. 22, n. 3, p. 935-952, set. 2014. ISSN 1806-9584. Disponível em: 〈>. Acesso em: 14 mar. 2018.

PISCITELLI, Adriana. Re-criando a (categoria) mulher?. Textos Didáticos, $\mathrm{n}^{\circ} 48$. A prática feminista e o conceito de gênero. Campinas, IFCH/UNICAMP, 2002, pp.7-42. Número organizado por Leila Mezan Algranti.

NICHOLSON, Linda. Interpretando o gênero. Revista Estudos Feministas, Florianópolis, v. 8, n. 2, p. 9, jan. 2000. ISSN 1806-9584. Disponível em: <https://periodicos.ufsc.br/index.php/ref/article/view/11917>. Acesso em: 18/05/2018.

SCOTT, Joan. Gênero: uma categoria útil de análise histórica. Educação e Realidade, Porto Alegre, v. 20, n. 2, jul./dez., 1995.

SOUSA, Raimundo. Gênero, autoginografia e performatividade em Margaret Skinnider. Ex aequo, Lisboa , n. 34, p. 127-141, dez. 2016. Disponível em: $<$ http://www.scielo.mec.pt/scielo.php?script=sci_arttext\&pid=S087455602016000200010\&lng=pt\&nrm=iso>. Acesso em: 06/06/2018.

STANTON, Domna. Autogynography: Is the Sbject Different? In: The Female Autograph: Theory and Practice of Autobiography from the Tenth to the Twentieth Century, editado por Domna Stanton, 5-22. Nova Iorque: New York Leterary Forum.

TELlAS, Vivi. Biodrama. Proyecto Archivos: seis documentales scénicos de Vivi Tellas. Cordoba: Universidad Nacional de Córdoba, 2017.

TVARDOVSKAS, Luana Saturnino. Dramatização dos corpos: arte contemporânea e crítica feminista no Brasil e na Argentina. São Paulo: Intermeios, 2015.

WOOLF, Virginia. Um teto todo seu. São Paulo: Tordesilhas, 2014. 
ANEXO A - Argentina / EBC

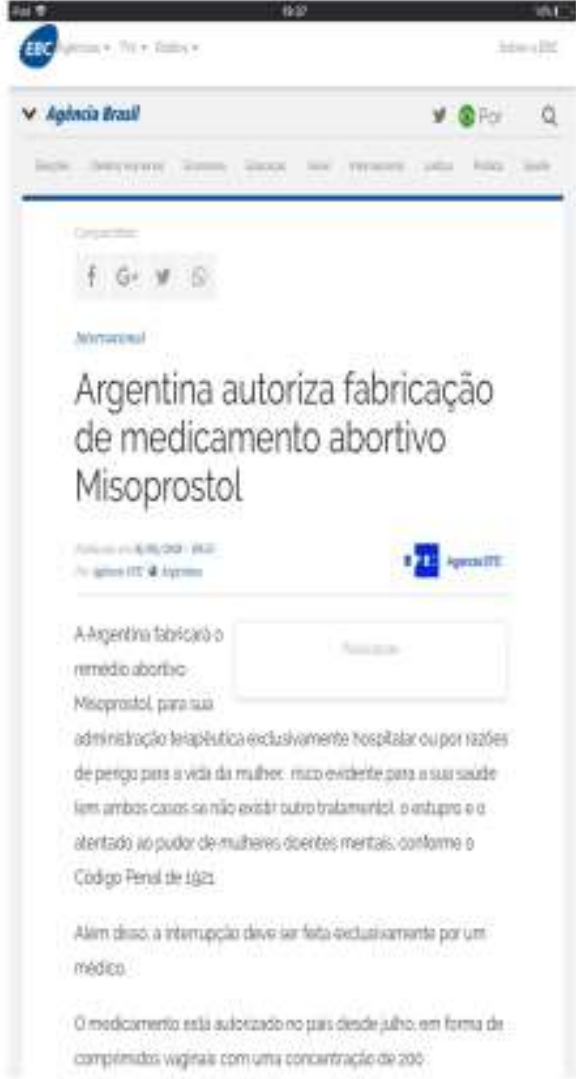

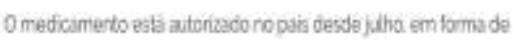
comprimidas vagrais cam umb concentraça de 202 microgramas

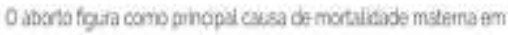
mas da metade das 23 provinclas argertinats

O Senado anger tun repetcou, en li de acosto utimo, epropto de

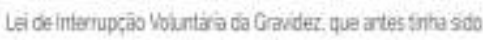
aprowaso pela Cimana dos Deplatidos

Administeccào Nacionai de Medcamentos. Alimenios e Tecnologa Madca da Argentro LAnmattintoma cis of firmaco sed prod.ados scb adenominuclo Misop aco:

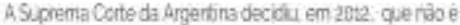

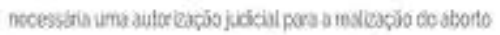 legai en cass de estupro foctemnou que es ficiente umb declaraçojo juarentoda por parte das vatimas 


\section{ANEXO B - Argentina / Estadão}

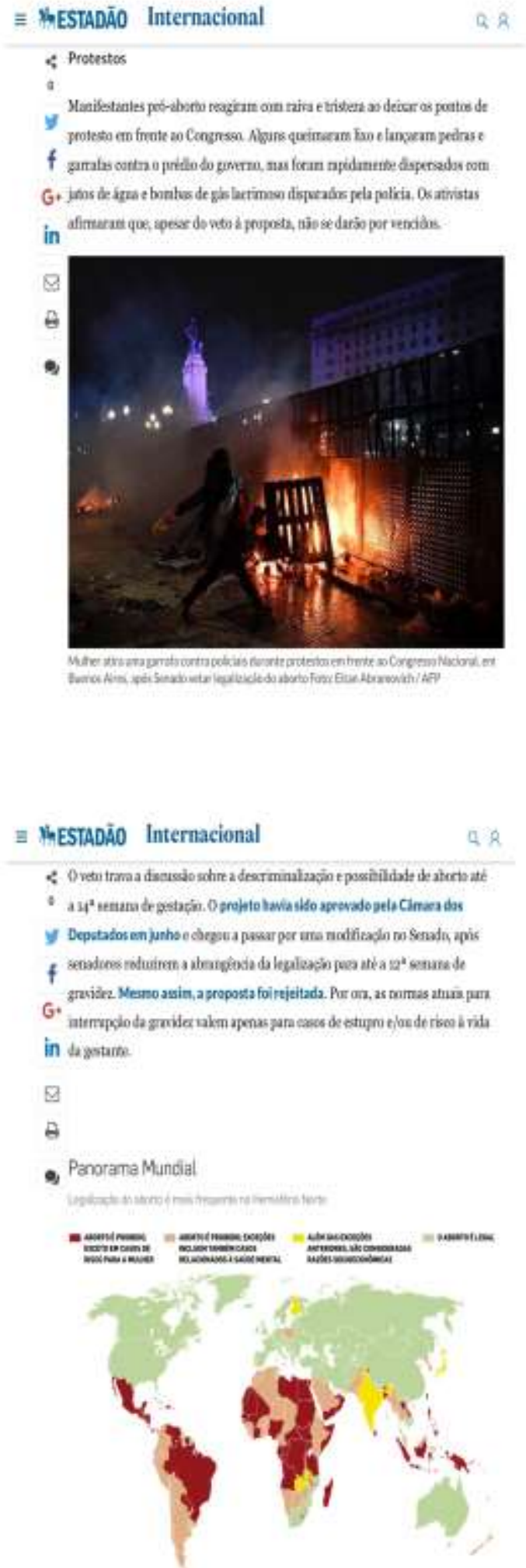

"0s votos mostratam que a Argentina ainda é un país que representa os valores familiares", disse a ativista antiaborto Victoria 0 suna, de 32 anos, que acompanhou o debate ao longo da quarta-féina até o inicio da madrugada desta quinta, 9. Manifestantes coatrários à interrupçào da gravidez, vestidos com moupas e lenços ołestes, balanģaram a bandeira da Argentina e fizeram uma celebração apús o resultado do Senado.

Mais cedn, o arcebispo de Baenos Aires, Mario Poli, conduziu uma missa na catedral da capital argentina na qual condenou o projeto. A celebraçâno foi transmitida em um telīo na Praça de Maio, localizada a um quilômetro do Congressa. A Igreja Católica, biderada pelo Papa Francisco, que é argentino, se posiciønou contrária à proposta e exetceu grande influència nos debates jelo pais.

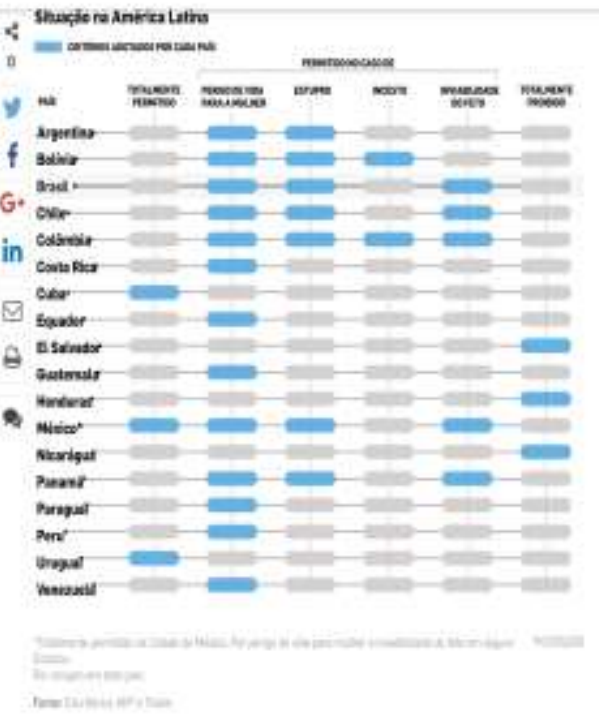




\section{ANEXO C - Argentina / Clarín em Português}

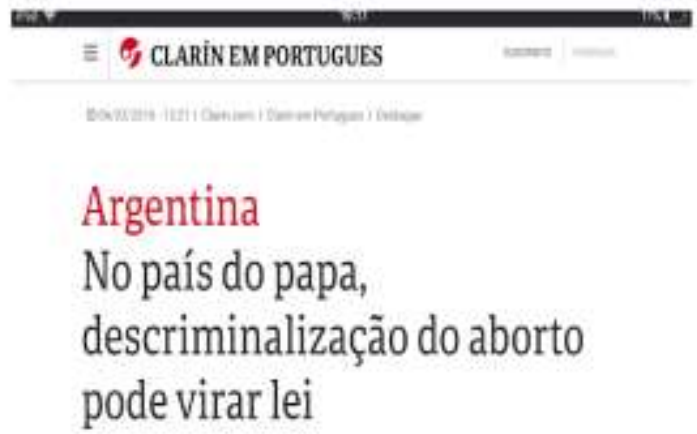

Oprojeto de let que prexể a interrupcảo da gestaçin com até 14 semanas chegou a Congresso Kacionalnestaterça $(06)$.A discussăo parlamentar do proieto está prevista para o próximodia vinte

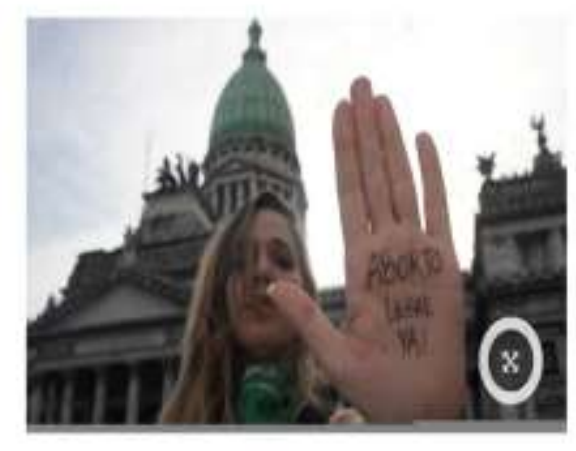

"Os votos mostraram que a Argentina ainda é um pais que representa os valores familiares", disse a ativista antiaborto Victoria Osuna, de 32 anos, que acompanhou o debate ao longo da quarta-feira até 0 início da madrugada desta quinta, 9. Manifestantes contrários à interrupção da gravidez, vestidos com roupas e lenços celestes, balançaram a bandeira da Argentina e fizeram uma celebração após o resultado do Senado.

Mais cedo, 0 arcebispo de Buenos Aires, Mario Poli, conduziu uma missa na catedral da capital argentina na qual condenou o projeto. A celebração foi transmitida em um telão na Praça de Maio, localizada a um quilômetro do Congresso. A Igreja Católica, liderada pelo Papa Francisco, que é argentino, se posicionou contrária à proposta e exerceu grande influência nos debates pelo país. 
ANEXO D - Argentina / Blog Anistia

\section{A votação pela legalização do aborto na Argentina foi um novo ponto de partida, e não um retrocesso}

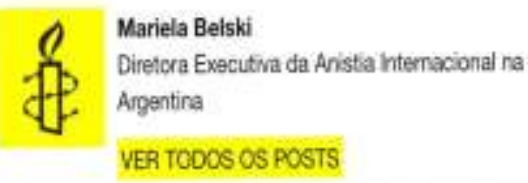

Tags: aborto, argertina
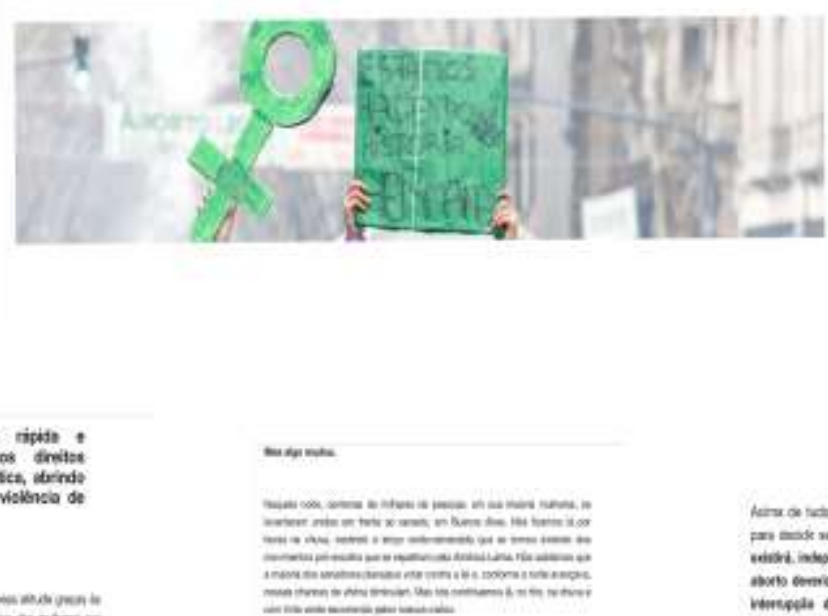

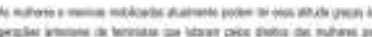

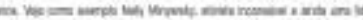

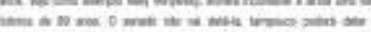
conimmint

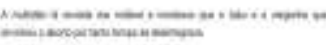

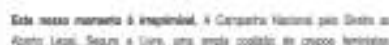

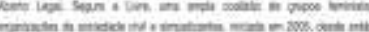

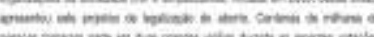

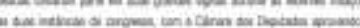

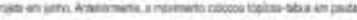

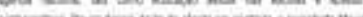

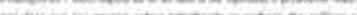

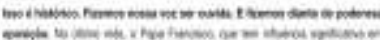

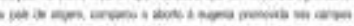

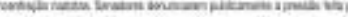

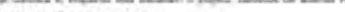

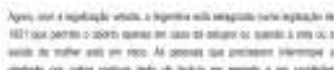

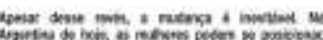

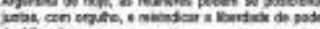

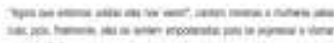

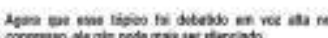

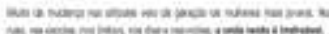

-

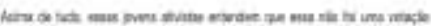

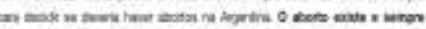

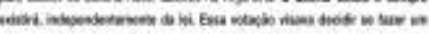

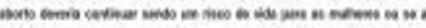

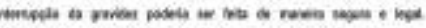

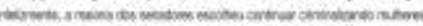

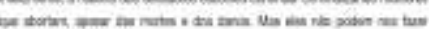
cotariendiventi

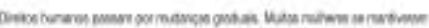

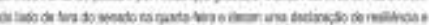

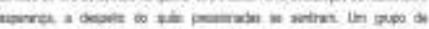

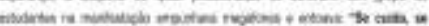

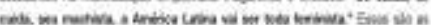

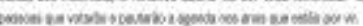

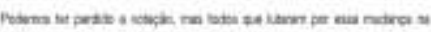

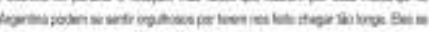

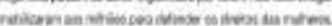

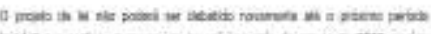

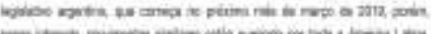

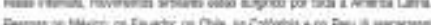

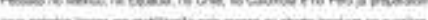

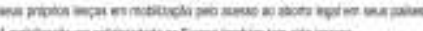


ANEXO E - Argentina / LIT-CI
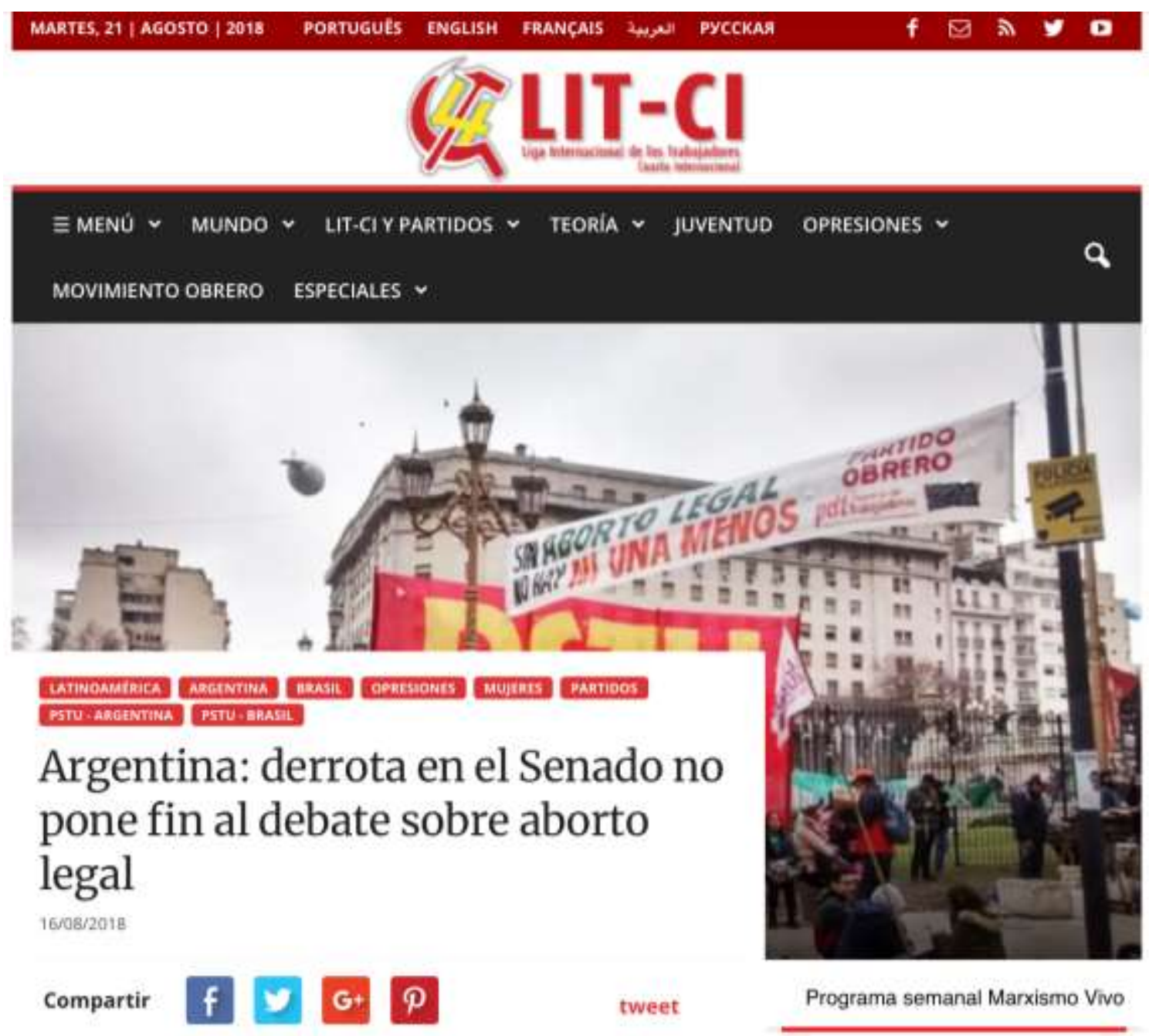

¡Es hora de volver a las calles e intensificar la lucha!

La lluvia fina y el frio cortante del miércoles 8 de agosto en Buenos Aires, no fueron suficientes para espantar a las personas que llenaron la Avenida de Mayo y los alrededores del Congreso argentino, donde los senadores debatian el proyecto de ley de legalización del aborto.

Por: Érika Andreassy, Secretaria de Mujeres del PSTU Brasil

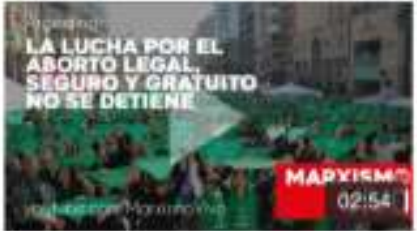

Argentina: La lucha por el aborto legal, seguro y gratuifo $>$ no se detiene

ropenarin

La lucha en Argentina por el abono legal, seguro y gratuito. repercutio en todo el mundo.

๑) 由 由 


\section{Relatores da ONU aplaudem mobilização das mulheres pelo aborto na Argentina}

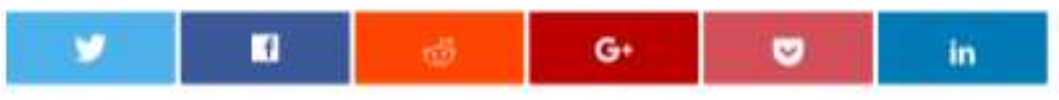

Imagem: CSP-Conlutas / Fonte: ONU

Especialistas em direitos humanos da ONU lamentam que o Senado argentino tenha rejeitado um projeto de lei que teria legalizado o aborto durante as primeiras 14 semanas de gravidez, considerando a decisão uma oportunidade perdida de promover os direitos das mulheres no país.

"A votação do Senado falhou com as mulheres na Argentina e, mais amplamente, com uma região que em geral tem leis muito restritivas em termos de interrupção da gravidez", disseram os especialistas.

"Os senadores garantiram a continuação de um legado arcaico apoiado por uma doutrina religiosa que incorpora estereótipos prejudiciais sobre o papel das mulheres na família e na sociedade, que são inerentemente discriminatórios e opressivos."

o Senado rejeitou o projeto de lei na quinta-feira, dia 9, por 38 votos a 31, após aprovação na Câmara dos Deputados em 14 de junho.

"Lamentamos profundamente que o Senado argentino não tenha aproveitado este momento histórico para demonstrar o compromisso do país em eliminar a discriminação contra as mulheres em sua legislação e promover os direitos sexuais e reprodutivos das mulheres $\mathrm{e}$ adolescentes, de acordo com suas obrigações internacionais de direitos humanos", disseram os especialistas. 